\title{
Summary Report: \\ Trace Substance Emissions From a Coal-Fired Gasification Plant
}

DCN 96-643-004-09

October 16, 1996

Prepared by:

Radian International LLC

8501 North MoPac Blvd.

Austin, Texas 78759

Project Manager

Greg Behrens

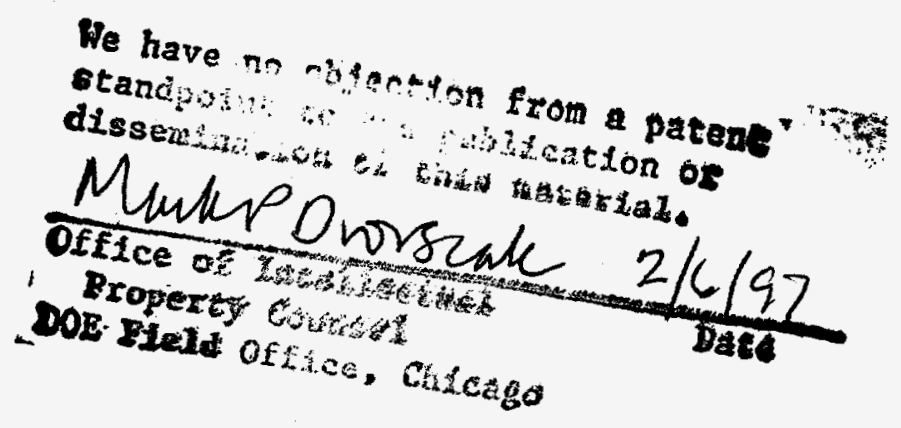

Authors

Al Williams

Bob Wetherold

David Maxwell

Prepared for:

Electric Power Research Institute

3412 Hillview Avenue

Palo Alto, California 94304

EPRI Project Manager

Paul Chu

Mike Epstein

\section{U.S. Department of Energy}

Pittsburgh Energy Technology Center

P.O. Box 10940

Pittsburgh, Pennsylvania 15236

DOE Project Manager

Lori Gould 


\section{DISCLAIMER OF WARRANTIES AND LIMITATION OF LIABILITIES}

THIS REPORT WAS PREPARED BY THE ORGANIZATION(S) NAMED BELOW AS AN ACCOUNT OF WORK SPONSORED OR COSPONSORED BY THE ELECTRIC POWER RESEARCH INSTITUTE, INC. (EPRI). NEITHER EPRI, ANY MEMBER OF EPRI, ANY COSPONSOR, THE ORGANIZATION(S) BELOW, NOR ANY PERSON ACTING ON BEHALF OF ANY OF THEM:

(A) MAKES ANY WARRANTY OR REPRESENTATION WHATSOEVER, EXPRESS OR IMPLIED, (I) WITH RESPECT TO THE USE OF ANY INFORMATION, APPARATUS, METHOD, PROCESS, OR SIMILAR ITEM DISCLOSED IN THIS REPORT, INCLUDING MERCHANTABILITY AND FITNESS FOR A PARTICULAR PURPOSE, OR (II) THAT SUCH USE DOES NOT INFRINGE ON OR INTERFERE WITH PRIVATELY OWNED RIGHTS, INCLUDING ANY PARTYS INTELLECTUAL PROPERTY, OR (III) THAT THIS REPORT IS SUITABLE TO ANY PARTICULAR USER'S CIRCUMSTANCE; OR

(B) ASSUMES RESPONSIBILTY FOR ANY DAMAGES OR OTHER LIABILTYY WHATSOEVER (INCLUDING ANY CONSEQUENTIAL. DAMAGES, EVEN IF EPRI OR ANY EPRI REPRESENTATIVE HAS BEEN ADVISED OF THE POSSIBILITY OF SUCH DAMAGES) RESULTING FROM YOUR SELECTION OR USE OF THIS REPORT OR ANY INFORMATION, APPARATUS, METHOD, PROCESS, OR SIMILARITEM DISCLOSED IN THIS REPORT.

ORGANIZATION(S) THAT PREPARED THIS REPORT

Radian International 山C

This paper was written with support of the U.S. Department of Energy under Contract no. DE-AC22-93PC93253. The Government reserves for itself and others acting on its behalf a royalty-free, nonexclusive, irrevocable, worldwide license for Governmental purposes to publish, distribute, translate, duplicate, exhibit and perform this copyrighted paper.

\section{ORDERING INFORMATION}

Requests for copies of this report should be directed to the EPRI Distribution Center, 207 Coggins Drive, P.O. Box 23205, Pleasant Hill, CA 94523, (510) 934-4212. There is no charge for reports requested by EPRI member utilities.

Electric Power Research Institute and EPRI are registered service marks of Electric Power Research Institute, Inc.

Copyright $\odot 1995$ Electric Power Research Institute, Inc. All rights reserved. 


\section{DISCLAMIER}

Portions of this document may be illegible in electronic image products. Images are produced from the best avallable original document. 


\section{DISCLAIMER}

This report was prepared as an account of work sponsored by an agency of the United States Government. Neither the United States Government nor any agency thereof, nor any of their employees, make any warranty, express or implied, or assumes any legal liability or responsibility for the accuracy, completeness, or usefulness of any information, apparatus, product, or process disclosed, or represents that its use would not infringe privately owned rights. Reference herein to any specific commercial product, process, or service by trade name, trademark, manufacturer, or otherwise does not necessarily constitute or imply its endorsement, recommendation, or favoring by the United States Government or any agency thereof. The views and opinions of authors expressed herein do not necessarily state or reflect those of the United States Government or any agency thereof. 


\section{ABSTRACT}

The U.S. Department of Energy (DOE), the Electric Power Research Institute (EPRI), and Louisiana Gasification Technology Inc. (LGTI) sponsored field sampling and analyses to characterize emissions of trace substances from LGTI's integrated gasification combined cycle (IGCC) power plant at Plaquemine, Louisiana. The results indicate that emissions from the LGTI facility were quite low, often in the ppb levels, and comparable to a wellcontrolled pulverized coal-fired power plant. 



\section{CONTENTS}

1 BACKGROUND AND SUMMARY .................................................................. 1-1

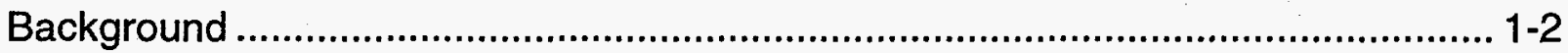

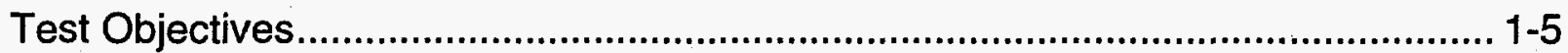

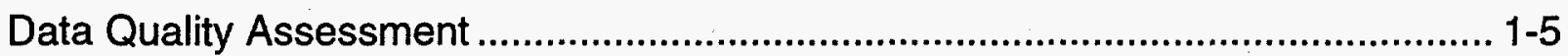

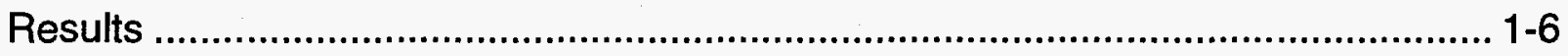

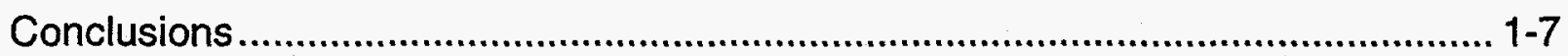

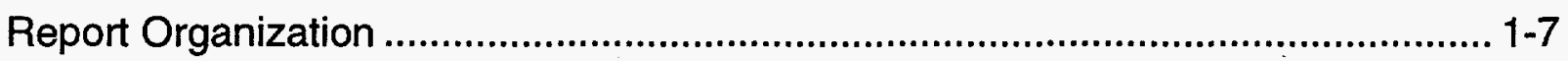

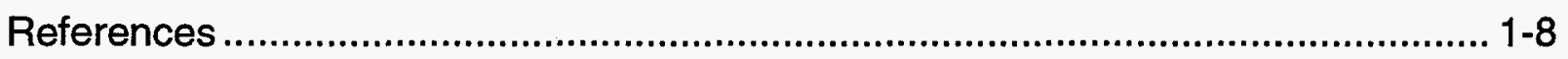

2 PROCESS DESCRIPTION ................................................................................ 2-1

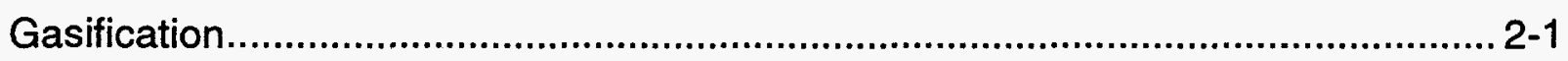

Gas Cooling and Particulate Removal.................................................................. 2-1

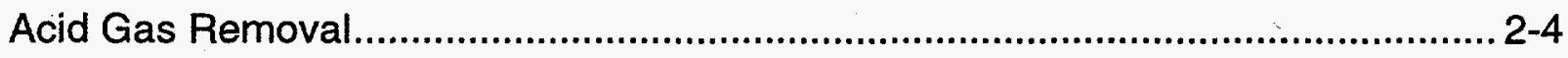

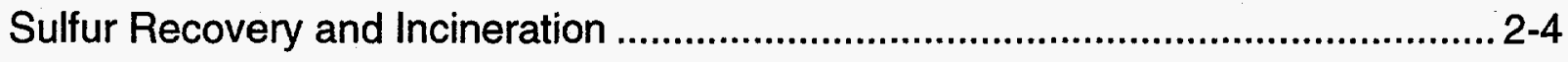

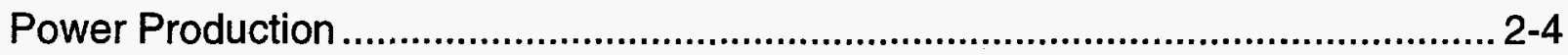

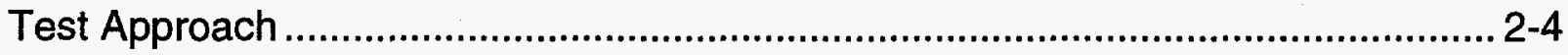

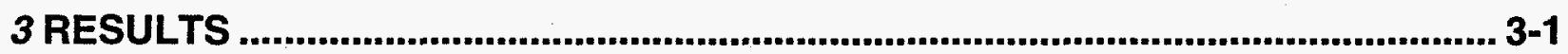

Analytical Results by Major Stream .....................................................................

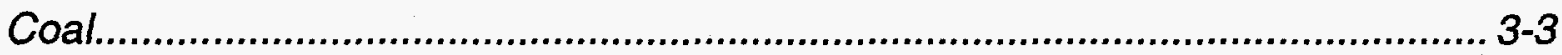

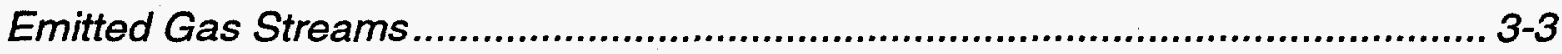

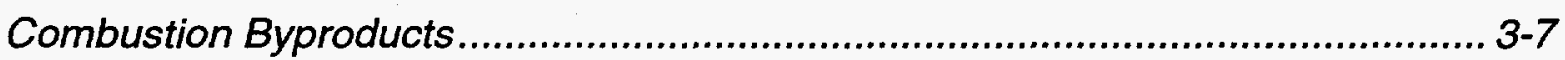

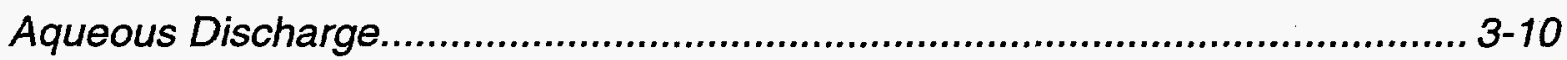

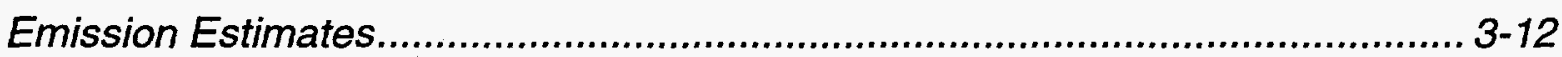

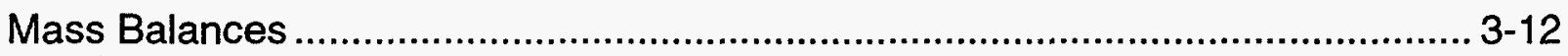

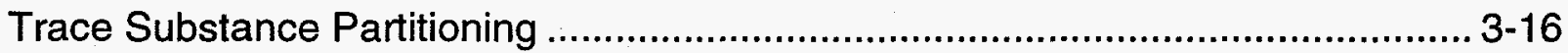

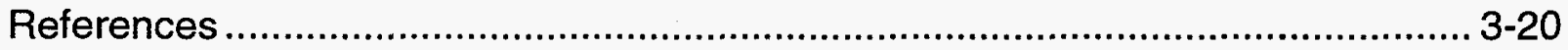


4 SPECIAL INTEREST TOPICS ........................................................................ 4-1

Mercury Measurements ................................................................... 4-2

Trace Elements in Reduced Gas Streams .............................................. 4-5

Hot Gas Testing ............................................................................... 4-7

References .................................................................................. 4-8

5 GLOSSARY .................................................................................................... 5-1

6 CONVERSION FACTORS...................................................................................... 6-1

APPENDIX A: Analytical Results ................................................................. 


\section{LIST OF TABLES}

1-1 Summary of Recent U.S. Operated IGCC Facilities ................................................. 1-4

2-1 Comparison of Typical PC Boiler and IGCC Systems ....................................................2-2

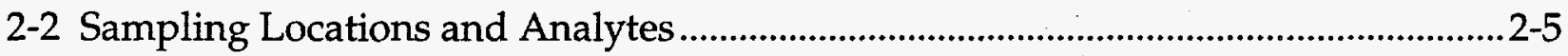

3-1 Solid Feed Stream Characteristics ................................................................................

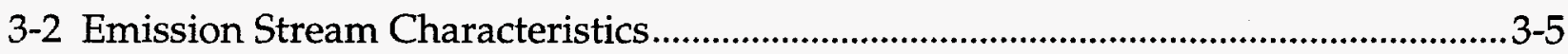

3-3 Combustion Byproduct Characteristics........................................................................

3-4 Aqueous Discharge Characteristics......................................................................... 3-10

3-5 Emission Factors for Selected Substances ...............................................................13

3-6 Selected Elemental Flows Around the LGTI Process ................................................. 3-15

4-1 Gold Amalgamation-CVAAS Impinger Train Configurations ....................................4-4

6-1 Conversion Factors for SI Units ................................................................................... 6-1 



\section{LIST OF FIGURES}

1-1 Example IGCC Process....................................................................................... 1-3

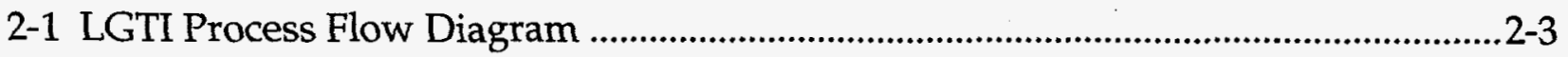

3-1 Process Parameters for the Gasification System............................................................3-2

3-2 Process Parameters for the Gas Turbine.......................................................................3-2

3-3 Comparison of Emission Stream Elemental Concentrations..........................................3-6

3-4 Comparison of Emission Streams Elemental Mass Flow ..............................................3-6

3-5 Removal of Selected Trace Elements Across the LGTI System .....................................3-8

3-6 Elemental Emission Factor Comparison of LGTI to Conventional Boiler with ESP and FGD Systems (Plant Yates) ............................................................................3-14

3-7 Volatile and Semivolatile Trace Substance Distribution ...............................................3-17

3-8 Non-Volatile Trace Substance Distribution at LGTI.....................................................3-18

3-9 Typical Partitioning of a Volatile Substance (Mercury) .................................................3-19

3-10 Typical Partitioning of a Non-Volatile Substance (Nickel) ........................................3-19

4-1 Schematic of CVAAS System ....................................................................................

4-2 Schematic of On-line AAS .......................................................................................

4-3 Trace Element Methods Comparison............................................................................ 4-7 


\section{BACKGROUND AND SUMMARY}

This project was a cooperative effort of the U.S. Department of Energy, the Electric Power Research Institute, and the Louisiana Gasification Technology Inc. to characterize the trace substance emissions from an advanced power system. The information gained from this project provides insight into the environmental performance of an integrated gasification combined cycle (IGCC) power plant. This report summarizes the findings originally published in December, 1995, in a comprehensive report prepared by Radian Corporation entitled "A Study of Toxic Emissions From a Coal-Fired Gasification Plant." ${ }^{1}$

Although not widely employed in the utility industry currently, IGCC is an option for future base-load capacity, replacing older conventional pulverized coal-fired boilers as those units are retired. The use of gas turbines to supply peak load demand is now standard practice. The quick startup time of these turbines and their compact, modular size, make them attractive. Unfortunately, they are thermally inefficient, and also fire high-grade fuels (natural gas and light oils). The extraction of useful heat from the gas turbine exhaust by steam generators increases the thermal efficiency of these systems significantly. This is a combined cycle configuration, i.e., the gas turbine generator is driven by expansion of the pressurized combustion gas, while a second generator is powered by steam generated by cooling the exhaust gas. In cogeneration applications, some of the steam also supplies process heating requirements. The heat of vaporization is also recovered (rather than rejected in the condenser), resulting in a very high thermal efficiency. Thermal efficiencies of an IGCC plant can range from $40-45 \%$, compared to $35 \%$ for a conventional pulverized coal-fired plant

With the deregulation of natural gas prices several years ago, many natural gas fired combined cycle systems were installed. Some of these systems were designed to also fire synthetic natural gas, which can be produced by coal gasification. Although natural gas prices are currently only at a slight premium relative to other energy sources, prices are expected to gradually rise as supplies dwindle. During times of reduced supply, public policy has traditionally been to divert supplies to residential and commercial users rather than industrial consumers. The demonstration of coal gasification integrated with combined cycle energy production would be an important step toward ensuring reliable power production for the future. Along with the economic assessment of various power technologies, the environmental impacts are of major concern. This report summarizes the environmental issues of a prototype IGCC system. 


\section{Background}

In 1990 the Electric Power Research Institute (EPRI) implemented the Field Chemical Emissions Monitoring Program (FCEM) as a means of measuring trace substances from a variety of utility combustion boilers. The data generated from this program was provided to the U.S. Environmental Protection Agency (EPA) for their use in addressing Title III of the Clean Air Act Amendments of 1990. In 1993, the Department of Energy (DOE) launched a parallel two-phase program with similar goals and objectives to ensure that the utility industry was well characterized. Phase I of the DOE program was completed in 1994. As a result of the Phase I effort, trace substance emissions data from eight coal-fired stations were provided to EPA. Phase II of the DOE program continued in 1995, expanding the targeted processes to include advanced power systems. This project was conducted as part of DOE's Phase II program, and was co-funded by EPRI, and the host site.

The host site was the Louisiana Gasification Technology Inc. (LGTI) facility located within the Dow Chemical complex in Plaquemine, Louisiana. The LGTI facility was selected by the U.S. Synthetic Fuels Corporation in 1987 to demonstrate the Dow Syngas process. At inception, it was partially funded by a Price Guarantee Commitment between Dow and the Synfuels Corporation. The guarantee has since been assumed by the Office of Synthetic Fuels, U.S. Treasury Department. Dow has formed a subsidiary, Destec Energy, which operates and markets their gasification technology.

Gasification is a partial oxidation process in which a solid, gas, or liquid feed (in this case coal) is reacted with oxygen and steam and converted to a synthesis gas (consisting mainly of hydrogen, carbon monoxide, and carbon dioxide). A high-Btu pipeline grade gas can be produced with additional processing. Coal gasification's major environmental advantages include the ability to reduce sulfur and nitrogen oxide emissions to extremely low levels. In addition, carbon dioxide emissions are lower per MW of power produced because of higher thermal efficiency. IGCC combines the thermal efficiency of a combined cycle combustion turbine (typically 50-60\%) with a less expensive fuel source (coal compared to natural gas). Typical pulverized coal unit steam-electrical efficiency is 34-36 percent. The combination of gasification with power production permits energy conversion efficiencies over 40 percent.

An example IGCC process is illustrated schematically in Figure 1-1. A summary of planned and operating IGCC facilities in the U.S. is presented in Table 1-1. ${ }^{2}$ 


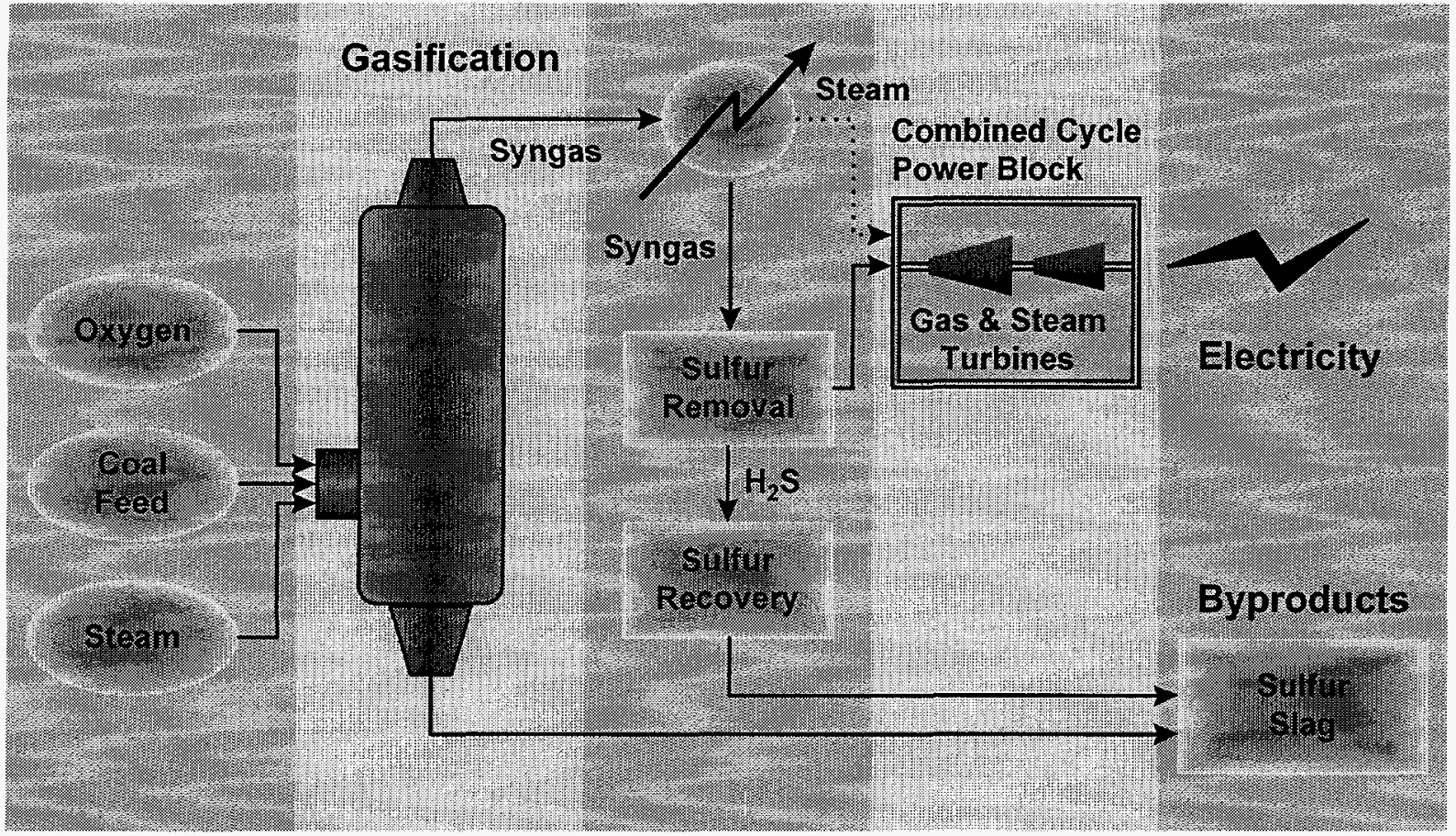

Figure 1-1

Example IGCC Process 
Table 1-1

Summary of Recent U.S. Operated IGCC Facilities

\begin{tabular}{|c|c|c|c|c|c|}
\hline \multirow[b]{2}{*}{$\begin{array}{l}\text { Net Power } \\
\text { (MWe) }\end{array}$} & \multirow{2}{*}{$\frac{\text { Plaquemine }}{160}$} & \multirow{2}{*}{$\begin{array}{c}\begin{array}{c}\text { Wabash } \\
\text { River }\end{array} \\
262\end{array}$} & \multirow{2}{*}{$\frac{\text { Pinon Pine }}{100}$} & \multicolumn{2}{|c|}{ Polk County } \\
\hline & & & & 255 & 25 (slip-stream) \\
\hline Coal & $\begin{array}{c}\text { Low-Sulfur } \\
\text { Subbituminous }\end{array}$ & $\begin{array}{l}\text { High-Sulfur } \\
\text { Bituminous }\end{array}$ & $\begin{array}{l}\text { Low-Sulfur } \\
\text { Bituminous }\end{array}$ & $\begin{array}{l}\text { High-Sulfur } \\
\text { Bituminous }\end{array}$ & $\begin{array}{l}\text { High-Sulfur } \\
\text { Bituminous }\end{array}$ \\
\hline $\begin{array}{l}\text { Gasification } \\
\text { Process }\end{array}$ & $\begin{array}{l}\text { Destec two- } \\
\text { stage, } \\
\text { entrained-bed } \\
\text { (slurry fed) }\end{array}$ & $\begin{array}{l}\text { Destec two- } \\
\text { stage, } \\
\text { entrained-bed } \\
\text { (slurry fed) }\end{array}$ & $\begin{array}{l}\text { KRW fluid-bed } \\
\text { (dry fed) }\end{array}$ & $\begin{array}{c}\text { Texaco } \\
\text { entrained-bed } \\
\text { (slurry fed) }\end{array}$ & $\begin{array}{c}\text { Texaco } \\
\text { entrained-bed } \\
\text { (slurry fed })\end{array}$ \\
\hline Oxidant & Oxygen & Oxygen & Air & Oxygen & Oxygen \\
\hline Gas Cleanup & $\begin{array}{c}\text { Low- } \\
\text { temperature }\end{array}$ & $\begin{array}{c}\text { Low- } \\
\text { temperature }\end{array}$ & $\begin{array}{c}\text { High- } \\
\text { temperature } \\
\left(1,000^{\circ} \mathrm{F}\right)\end{array}$ & $\begin{array}{c}\text { Low- } \\
\text { temperature }\end{array}$ & $\begin{array}{c}\text { High- } \\
\text { temperature } \\
\left(1,000^{\circ} \mathrm{F}\right)\end{array}$ \\
\hline $\begin{array}{l}\text { Particulate } \\
\text { Control }\end{array}$ & Water scrubber & $\begin{array}{c}\text { Hot gas barrier } \\
\text { filter and water } \\
\text { scrubber }\end{array}$ & $\begin{array}{c}\text { Cyclones and } \\
\text { hot gas barrier } \\
\text { filter }\end{array}$ & Water scrubber & $\begin{array}{c}\text { Cyclone and } \\
\text { hot gas barrier } \\
\text { filter }\end{array}$ \\
\hline Sulfur Control & $\begin{array}{l}\text { Selectamine }^{\mathrm{TM}} \\
\text { scrubber and } \\
\text { Selectox } \\
\text { plant }\end{array}$ & $\begin{array}{l}\text { Selectamine }^{\mathrm{TM}} \\
\text { scrubber and } \\
\text { Claus plant }\end{array}$ & $\begin{array}{c}\text { In-situ } \\
\text { absorption } \\
\text { (limestone) and } \\
\text { external-bed } \\
\text { dry adsorption } \\
\text { (zinc oxide) }\end{array}$ & $\begin{array}{c}\text { Amine } \\
\text { scrubber and } \\
\mathrm{H}_{2} \mathrm{SO}_{4} \text { plant }\end{array}$ & $\begin{array}{c}\text { External } \\
\text { moving-bed } \\
\text { dry adsorption } \\
\text { (zinc titanate) } \\
\text { and } \mathrm{H}_{2} \mathrm{SO}_{4} \\
\text { plant }\end{array}$ \\
\hline $\begin{array}{l}\text { Overall Sulfur } \\
\text { Recovery }\end{array}$ & $85 \%$ design & $99 \%$ design & $99+\%$ design & $98 \%$ design & $99+\%$ design \\
\hline NOx Control & Steam dilution & Steam dilution & & $\begin{array}{l}\text { Nitrogen and } \\
\text { steam dilution }\end{array}$ & \\
\hline $\begin{array}{l}\text { Ammonia } \\
\text { Control }\end{array}$ & Water scrubber & Water scrubber & & Water scrubber & \\
\hline $\begin{array}{l}\text { Chloride/ } \\
\text { Fluoride } \\
\text { Control }\end{array}$ & Water scrubber & Water scrubber & & Water scrubber & $\begin{array}{l}\text { External fluid- } \\
\text { bed dry } \\
\text { adsorption } \\
\left(\mathrm{NaHCO}_{3}\right)\end{array}$ \\
\hline
\end{tabular}




\section{Test Objectives}

The competitive nature of the power industry will drive the utilization of efficient technology. As one of the few operating plants of this type in the U.S., EPRI and DOE recognized the importance of characterizing the emissions from the LGTI unit. The test objectives for this program fell into four categories:

- Quantitate emissions from the IGCC process;

- Calculate mass balances for selected conserved species;

- Determine control efficiencies for process sub-systems; and

- Design, construct, and demonstrate a retractable sampling system for collecting particulate and gas samples from a high-temperature, high-pressure reduced gas environment.

The test results provide the utility industry with valuable insights into the environmental performance of the IGCC process and provide a basis for a comparison to conventional coal-fired systems.

\section{Data Quality Assessment}

The measurement data obtained from this project were subjected to a number of quality control $(\mathrm{QC})$ checks designed to assess the completeness, representativeness, and comparability of the results. The results of these QC checks were evaluated and compared to the data quality objectives (DQOs) established at the onset of this project for precision, accuracy, and representativeness of individual sample measurements. Quality control checks that fail to meet the DQOs do not necessarily render the data unacceptable; however, they may affect the representativeness and comparability of the results reported. The DQOs are not intended for use as acceptance criteria, but rather they are used as empirical estimates of the precision and accuracy expected from existing reference measurement methods considered acceptable for providing meaningful results.

Three major questions were addressed during this assessment: First, was the plant operating in a normal condition? Second, was the sampling of process streams representative, and last, were the analytical results obtained correct? Each of these concerns was addressed in this project.

Process data were collected and analyzed and they indicate the plant operation was very consistent, with major process conditions varying by less than $\pm 10 \%$ during sample collection periods. Samples were collected from the emission streams (gas turbine exhaust, incinerator, slag) with minimal problems and are considered to be representative of normal process operation. 
The sampling methods applied to the input and emissions streams produced results that met the data quality objectives and are supported by material balance closures for the overall plant. The sampling methods applied to internal process streams are still developmental in nature and have not been validated for reduced gas matrices. Consequently, much of the internal data for vapor phase trace metals is considered to be semi-quantitative. In addition, several of the internal sampling points were in lessthan-ideal locations for representative sample collection.

Analytical methods were applied to samples collected from both oxidizing (containing excess oxygen) and reducing (containing hydrogen or substoichiometric amounts of oxygen) process streams. Analytical results for those samples collected from the input and emission streams (coal, slag, sweet water, incinerator stack gas, and turbine stack gas) indicate that the analytical data are, with very few exceptions, of good quality and acceptable for use. This statement implies that the bias and precision of the results met the project data quality objectives and that minimal contamination was identified as a result of reagent, sampling, or analytical procedures. The material balances performed around the entire plant also support the reasonableness of the data obtained for the input and output streams of the plant.

\section{Results}

- Emissions of hazardous air pollutants from the LGTI facility were quite low. For many substances the combined emission factors (turbine and incinerator stack) were lower than well-controlled pulverized coal steam-electric plants. QA/QC results for the emissions streams show, among other things, that $72 \%$ (21 of 29) of the elemental balances met the data quality objectives for material balance closures of $70-130$ percent.

- Results show that emissions of major elements $(\mathrm{Al}, \mathrm{Ca}, \mathrm{Na}, \mathrm{Fe})$ are controlled to a level of 99.999 percent. Other trace elements that are considered volatile (or semivolatile) are controlled by $90-99$ percent. Only mercury cadmium, and selenium are controlled by less than 90 percent.

- Results from many of the internal process streams show that traditional sampling and analytical methods used in oxidized gas matrices (i.e., flue gas) are not quantitative for reduced gas matrices. Consequently, mass flows for trace elements in internal streams are uncertain.

- A high-pressure, high-temperature sampling system was successfully designed, built, and tested during this project, allowing for representative samples to be collected from the hot $\left(1,000^{\circ} \mathrm{F}\right)$ synthesis gas.

- Unique measurements for mercury produced insights into the sampling and analytical methodologies that will be required for future characterization of mercury in reduced gases. 


\section{Conclusions}

The prototype IGCC system at LGTI emits trace substances at levels equal to or below well-controlled pulverized coal boilers. Conceptually, it is easy to understand how most pollutants of concern are controlled, even though many of the internal measurements are not quantitative.

In the gasifier, large quantities of water are present in a vapor state, due to both the coal-slurry water and the oxidation reaction. The raw gas contains $\sim 30 \%$ moisture. As the gas is cooled, this moisture condenses and acts as a very effective agglomeration agent. Since the coal ash is never in a dry environment, the particulate scrubber is very effective at removing particles. As the gas is cooled to about $130^{\circ} \mathrm{F}$ in the Selectamine ${ }^{\mathrm{TM}}$ solution, the moisture level drops to $1 \%$ or less. In this solution, the reduced sulfur species are absorbed. It is expected that most organo-metallic species would also be removed to a high degree in the multi-tray absorption tower. After this conditioning, the synthesis gas is combusted in a turbine. Turbine operation requires that the gas be very clean, especially with respect to alkaline elements and particulate matter. The cleanup capabilities of the prototype unit are confirmed by the low emission levels seen from the turbine.

When these results are considered in developing future IGCC units, one must evaluate the type of gas cleanup employed. Newer systems are attempting to employ cleanup methods at high temperatures $\left(\sim 1000^{\circ} \mathrm{F}\right)$. Hot gas sulfur removal systems improve the thermal efficiency significantly, but may not be quite as effective at removing vapor phase elements and compounds. These substances would also pass through the turbine as emissions. The developmental work performed during this project to attempt quantifying vapor phase elements in reduced gases identified several analytical problem areas that must be addressed. The hot-gas probe demonstrated that these streams (high temperature and pressure) could be safely sampled.

\section{Report Organization}

Section 2 of this report contains a description of the process and describes the test approach that was used. Results are presented in Section 3. Section 4 contains a discussion of special interest topics including mercury and other trace element measurements in reduced gas matrices. A glossary and table for SI conversion units are presented in Sections 5 and 6, and Appendix A contains a comprehensive data summary of all analytical results obtained during the program. 


\section{References}

1 A Study of Toxic Emissions from a Coal-Fired Gasification Plant. Radian Corporation. Report DE-AC2293PC93253, U.S. Department of Energy, Pittsburgh Energy Technology Center, Pittsburgh, PA, December 1995.

$2 \quad$ Mike Epstein, Electric Power Research Institute, July 1996. 


\section{2}

\section{PROCESS DESCRIPTION}

At full capacity, the LGTI Plant produces $30,000 \mathrm{MM}$ Btu of equivalent syngas per day, consuming approximately 2,200 tons per day of western subbituminous coal from the Rochelle mine in the Powder River Basin in Wyoming. This is the equivalent of $160 \mathrm{MW}$ of net power, considering both electricity and process steam production.

The gasification process is radically different from conventional pulverized coal-fired (PC) boilers. The primary distinction is the energy transfer mechanism. In a conventional boiler, the energy released during combustion is transferred directly to water/steam. In the IGCC system, the coal is converted to a gas that is subsequently used to produce power. Major differences are summarized in Table 2-1.

A process flow diagram showing the LGTI process and sample point locations is presented in Figure 2-1. The process is comprised of five main sub-units, each of which is described in the following sections.

\section{Gasification}

The gasifier is a high-temperature, oxygen blown, two-stage, entrained-flow, slagging design. Coal slurry is pumped into the reactor and mixed with steam and oxygen in the burner nozzles. Oxygen is controlled to maintain the reactor temperature within a narrow range. Sulfur in the coal is converted almost totally to $\mathrm{H}_{2} \mathrm{~S}$ with small amounts of COS, while nitrogen is converted to ammonia, nitrogen and trace amounts of cyanide and thiocyanate. Coal ash fuses into molten slag that is drained from the reactor through a let-down system. The large majority of all trace and major elements are captured in the slag.

\section{Gas Cooling and Particulate Removal}

The hot raw syngas produced in the gasifier passes through several cooling and cleaning systems. The gas is first cooled in a convective fire-tube heat exchanger producing steam. Next, entrained particulate matter (char) is removed from the gas by a wet venturi scrubber system. The char is returned to the gasifier for complete combustion. The gas is cooled further to near ambient temperature prior to the Selectamine ${ }^{\mathrm{TM}}$ sulfur removal process. The condensate resulting from this gas cooling step contains substantial amounts of soluble sulfide, ammonia, and carbon dioxide. At 
this point, the gas contains very little particulate matter. It has an appreciable amount of $\mathrm{H}_{2} \mathrm{~S}$ and some organo-metallic compounds may be present at low levels.

Table 2-1

Comparison of Typical PC Boiler and IGCC Systems

Element

Typical PC Boiler

Operating Principle
Fuel is combusted, heat is transferred to produce highpressure steam that drives a turbine.

\section{Typical IGCC System}

Fuel is partially combusted which results in gasification of remaining fuel. The highpressure synthesis gas is expanded and combusted in a gas turbine to produce power. Heat recovery systems raise steam for additional power production.

\begin{tabular}{|c|c|c|}
\hline Oxidant & Air & $\begin{array}{l}\text { Air or oxygen in the gasifier. } \\
\text { Air in the combustion turbine. }\end{array}$ \\
\hline System pressure & 1 atmosphere & 25-40 atmospheres \\
\hline Coal Sulfur & $\begin{array}{l}\text { Converted to } \mathrm{SO}_{2} \text { in the } \\
\text { combustion process and } \\
\text { generally removed via a flue } \\
\text { gas desulfurization process } \\
\text { such as a limestone scrubber. }\end{array}$ & $\begin{array}{l}\text { Converted primarily to } \mathrm{H}_{2} \mathrm{~S} \\
\text { and some COS. } \mathrm{H}_{2} \mathrm{~S} \text { and } \mathrm{COS} \\
\text { are removed from the } \\
\text { synthesis gas prior to } \\
\text { combustion and recovered as } \\
\text { elemental sulfur or sulfuric } \\
\text { acid. }\end{array}$ \\
\hline Coal nitrogen & Converted to $\mathrm{NO}_{x}$ & $\begin{array}{l}\text { Converted to ammonia and } \\
\text { nitrogen. }\end{array}$ \\
\hline Process Solids & $\begin{array}{l}\text { Typically } 80 \% \text { of the ash } \\
\text { produced from the } \\
\text { combustion process is } \\
\text { collected in a downstream } \\
\text { control device (such as an } \\
\text { ESP). } 20 \% \text { of the coal ash is } \\
\text { recovered as bottom ash. }\end{array}$ & $\begin{array}{l}\text { Virtually all of the coal ash is } \\
\text { recovered as an inert slag } \\
\text { from the gasifier. }\end{array}$ \\
\hline Thermal Efficiency & $34-36 \%$ & $\begin{array}{l}>40 \% \text { (typical full-scale } \\
\text { commercial system }\end{array}$ \\
\hline
\end{tabular}




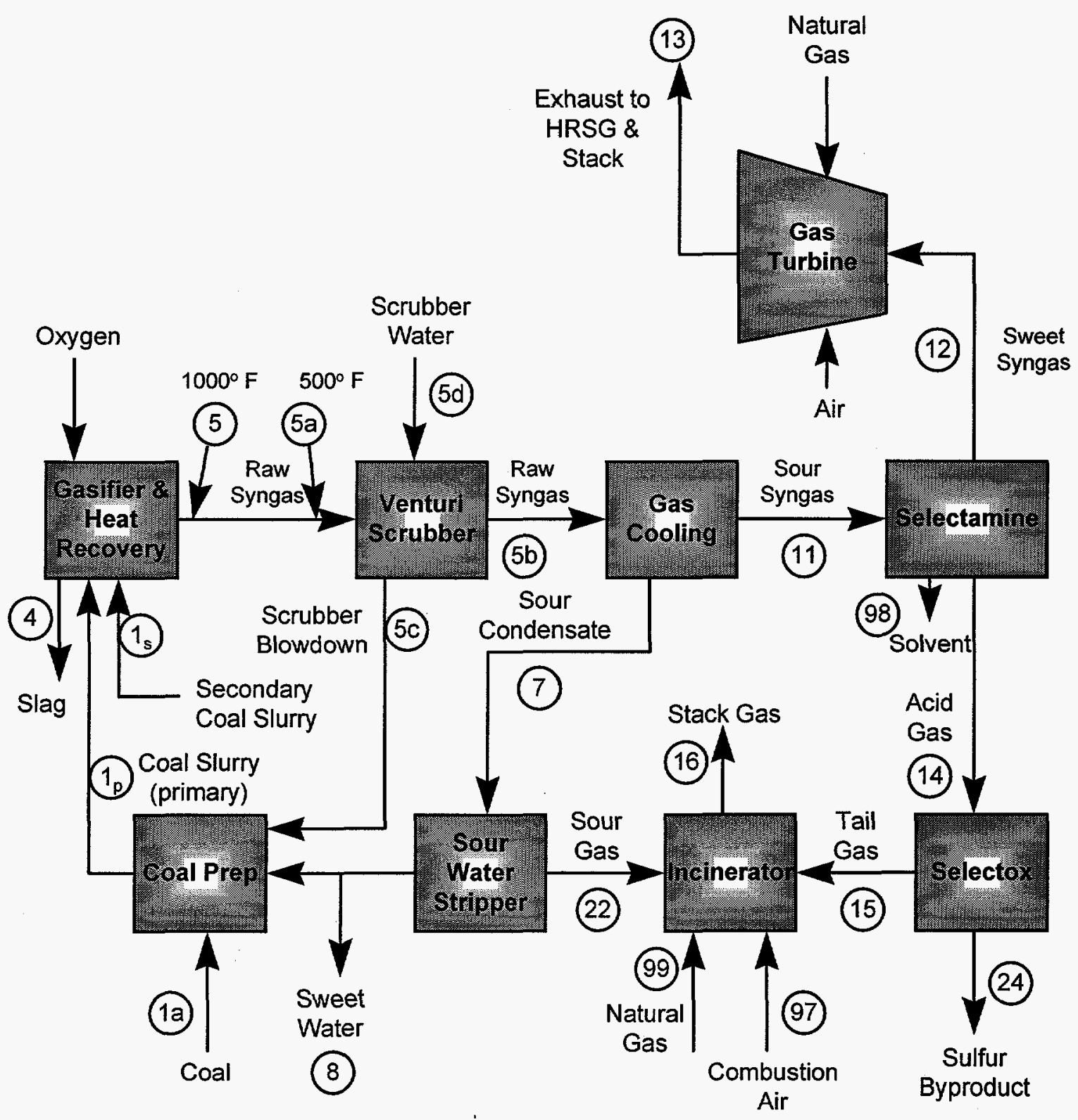

$\bigcirc$ Denotes Sampling Location Number

Figure 2-1

LGTI Process Flow Diagram 


\section{Acid Gas Removal}

Dow's Selectamine ${ }^{\mathrm{TM}}$ acid gas removal process removes over $97 \%$ of the sulfur from the sour syngas. The principal ingredient in the Selectamine ${ }^{\mathrm{TM}}$ solvent is methyl diethanolamine (MDEA). The acid gases are absorbed in the MDEA solution and the sweetened product gas is sent by pipeline to the power plant for use as gas turbine fuel. The concentrated acid gas, composed primarily of $\mathrm{H}_{2} \mathrm{~S}, \mathrm{CO}_{2}$, and water, is recovered by stripping the rich MDEA solvent. The concentrated acid gas stream is sent to the sulfur recovery unit. Periodically, the MDEA solution is regenerated to remove heat-stable salts that are formed. In addition, sludge in the storage tank is periodically removed and discarded.

\section{Sulfur Recovery and Incineration}

The Selectox ${ }^{\mathrm{TM}}$ process is used to recover the sulfur from the acid gas produced in the Selectamine ${ }^{\mathrm{TM}}$ unit. This process uses a fixed bed of catalyst to oxidize a portion of the $\mathrm{H}_{2} \mathrm{~S}$ to $\mathrm{SO}_{2}$ prior to the sulfur production. Claus reactors then catalyze an oxidizationreduction (redox) reaction between the $\mathrm{H}_{2} \mathrm{~S}$ and $\mathrm{SO}_{2}$ to produce elemental sulfur. Because low-sulfur coal is used as the feedstock, the design removal efficiency was only 85 percent. The tail gas from the Selectox ${ }^{\mathrm{TM}}$ unit is fed to an incinerator to oxidize the remaining $\mathrm{H}_{2} \mathrm{~S}$ to $\mathrm{SO}_{2}$. The incinerator stack gas is exhausted to the atmosphere.

\section{Power Production}

Clean syngas from the acid gas removal unit is co-fired with natural gas in two gas turbines at Dow's Power II facility. The two Westinghouse WD501-D5 gas turbines burn either natural gas or a blend of syngas and natural gas and they can produce up to 105MW of electrical power each. In addition, a waste heat boiler recovers much of the energy in the turbine exhaust and produces steam for the Dow Chemical facility. During the testing, approximately $63 \%$ of the Btu content of the fuel to the turbines was from syngas and $37 \%$ was from natural gas. Emission factors were determined on a total energy basis (coal and natural gas).

\section{Test Approach}

Due to the number and type of sampling locations as well as the groups of analytes measured, it was necessary to employ a phased approach during the test program. The majority of the plant was characterized during three consecutive test periods in November 1994. In a fourth test period, conducted in May 1995, a hot-gas probe was used to gather high-temperature/pressure samples from the raw syngas. Table 2-2 lists the sampling locations (the number refers to the location on Figure 2-1), the test period, and the types of analytes measured. Testing was coordinated so that inlet and outlet 
process streams of the various sub-units were characterized simultaneously. Samples were collected in triplicate (at a minimum) to provide an acceptable level of statistical significance.

Table 2-2

Sampling Locations and Analytes

\begin{tabular}{|c|c|c|c|}
\hline Location & Stream & Test Period & Analytes \\
\hline \multirow[t]{2}{*}{$1 \mathrm{a}$} & Coal pile & $1,2,3$ & Metals, ultimate, proximate, anions \\
\hline & & 3 & Radionuclides \\
\hline $1 \mathrm{p}, 1 \mathrm{~s}$ & Coal slurry & $1,2,3$ & Metals, ultimate, proximate, anions \\
\hline \multirow[t]{2}{*}{4} & Slag & $1,2,3$ & Metals, ultimate, proximate, anions \\
\hline & & 3 & Radionuclides \\
\hline 5 & Raw gas, $1,000^{\circ} \mathrm{F}$ & 4 & $\begin{array}{l}\text { Vapor: metals, } \mathrm{Cl}, \mathrm{F}, \mathrm{NH}_{3}, \mathrm{HCN} \text { Particulate: } \\
\text { metals }\end{array}$ \\
\hline $5 \mathrm{a}$ & Raw gas, $500^{\circ} \mathrm{F}$ & 3 & Metals, $\mathrm{C}_{1}-\mathrm{C}_{10}, \mathrm{Cl}, \mathrm{F}, \mathrm{NH}_{3}, \mathrm{HCN}$ \\
\hline $5 a$ & Raw gas, $500^{\circ} \mathrm{F}$ & $\begin{array}{l}\text { probe } \\
\text { shakedown } \\
\text { test }\end{array}$ & Particulate: metals \\
\hline $5 b$ & $\begin{array}{l}\text { Raw gas, } \\
\text { scrubbed }\end{array}$ & 3 & Metals, $\mathrm{C}_{1}-\mathrm{C}_{10}, \mathrm{Cl}, \mathrm{F}, \mathrm{NH}_{3}, \mathrm{HCN}$ \\
\hline \multirow[t]{2}{*}{$5 c$} & $\begin{array}{l}\text { Scrubber } \\
\text { blowdown (char) }\end{array}$ & 3 & Metals, ultimate, proximate, anions \\
\hline & (filtrate) & 3 & $\begin{array}{l}\text { Metals, ultimate, proximate, anions, } \\
\text { ammonia, cyanide, suspended solids }\end{array}$ \\
\hline $5 d$ & Scrubber water & 3 & $\begin{array}{l}\text { Metals, ultimate, proximate, anions, } \\
\text { ammonia, cyanide }\end{array}$ \\
\hline 7 & Sour condensate & 2 & $\begin{array}{l}\text { Metals, cyanide, volatile/semivolatile } \\
\text { organics, aldehydes, anions, ammonia, } \\
\text { phenol, sulfide, water quality }\end{array}$ \\
\hline 8 & Sweet water & 2 & $\begin{array}{l}\text { Metals, cyanide, volatile/semivolatile } \\
\text { organics, aldehydes, anions, ammonia, } \\
\text { phenol, sulfide, water quality }\end{array}$ \\
\hline 11 & Sour syngas & 1 & $\begin{array}{l}\text { Particulates, metals, } \mathrm{C}_{1}-\mathrm{C}_{10} \text {, volatile } \\
\text { organics, major gases, sulfur species, } \\
\text { semivolatile organics, aldehydes, } \mathrm{Cl}, \mathrm{F} \text {, } \\
\mathrm{NH}_{3}, \mathrm{HCN}\end{array}$ \\
\hline
\end{tabular}


Table 2-2

Sampling Locations and Analytes

$\begin{array}{lll}\text { Location } & \text { Stream } & \text { Test Period }\end{array}$

\begin{tabular}{|c|c|c|c|}
\hline 12 & Sweet syngas & 1 & $\begin{array}{l}\text { Particulates, metals, } \mathrm{C}_{1}-\mathrm{C}_{10} \text {, volatile } \\
\text { organics, major gases, sulfur species, } \\
\text { semivolatile organics, aldehydes, } \mathrm{Cl}, \mathrm{F} \text {, } \\
\mathrm{NH}_{3}, \mathrm{HCN}\end{array}$ \\
\hline 13 & Turbine Exhaust & 1 & $\begin{array}{l}\text { Particulates, PM-10, metals, VOST, } \\
\text { semivolatile organics, aldehydes, } \mathrm{Cl}, \mathrm{F}, \mathrm{NH}_{3} \\
\mathrm{HCN}, \mathrm{H}_{2} \mathrm{SO}_{4}, \mathrm{CEM} \text { gases }\end{array}$ \\
\hline 14 & Acid gas & 1 & $\begin{array}{l}\text { Metals, } \mathrm{C}_{1}-\mathrm{C}_{10} \text {, major gases, sulfur species, } \\
\text { semivolatile organics, } \mathrm{Cl}, \mathrm{F}, \mathrm{NH}_{3}, \mathrm{HCN}\end{array}$ \\
\hline \multirow[t]{2}{*}{15} & Tail gas & 1 & $\begin{array}{l}\text { Metals, } \mathrm{C}_{1}-\mathrm{C}_{10} \text {, major gases, sulfur species, } \\
\text { semivolatile organics, } \mathrm{NH}_{3}, \mathrm{HCN}\end{array}$ \\
\hline & & 2 & $\begin{array}{l}\mathrm{C}_{1}-\mathrm{C}_{10} \text {, sulfur species, semivolatile organics, } \\
\mathrm{NH}_{3}, \mathrm{HCN} \text { CEM gases }\end{array}$ \\
\hline 16 & Incinerator stack & 2 & $\begin{array}{l}\text { Particulates, PM-10, metals, VOST, sulfur } \\
\text { species, semivolatile organics, aldehydes, } \mathrm{Cl} \text {, } \\
\mathrm{F}, \mathrm{NH}_{3}, \mathrm{HCN}, \mathrm{H}_{2} \mathrm{SO}_{4} \text { CEM gases }\end{array}$ \\
\hline 22 & Sour gas & 2 & $\mathrm{C}_{1}-\mathrm{C}_{10}$, major gases, $\mathrm{NH}_{3}, \mathrm{HCN}$ \\
\hline 24 & Sulfur & 1 & Metals, ultimate, proximate \\
\hline 97 & Combustion air & 2 & $\begin{array}{l}\mathrm{C}_{1}-\mathrm{C}_{10}, \text { major gases, sulfur species, } \mathrm{NH}_{3}, \\
\mathrm{HCN}\end{array}$ \\
\hline \multirow[t]{2}{*}{98} & $\begin{array}{l}\text { Selectamine }{ }^{\mathrm{TM}} \\
\text { solvent }\end{array}$ & 1 & Ash, volatile organics, heat stable salts \\
\hline & & 3 & Ash, heat stable salts \\
\hline 99 & Natural gas & 2 & Metals, $C_{1}-C_{10}$, sulfur species \\
\hline
\end{tabular}




\section{3 \\ RESULTS}

Highlights of the comprehensive test results are presented in this section. Specifically, the feed coal and the four emission streams are discussed. The reader is referred to the comprehensive report ${ }^{1}$ for a complete discussion of all results. Analytical result summaries of all the data obtained during the comprehensive test are contained in Appendix A of this document.

Process operation trend plots are presented to illustrate the stability of plant operations during the testing. The process was very stable during all test periods and can be considered representative of normal operations. The values in Figure 3-1 show the percent coal feed slurry solids, the gasifier temperature, and the sweet syngas flow rates plotted as the percent of the average value. The relative deviation during the period is also shown. The composition and concentration of trace contaminants can be affected by gasifier temperature, so a consistent temperature in the gasifier is an important indicator of stable process operation. The feed slurry rate has not been plotted, but remained constant throughout the testing, ranging between 412 and $420 \mathrm{gpm}$. The percent solids in the coal feed slurry is plotted in Figure 3-1 and again indicates the process stability during the test program. Finally, the sweet syngas flow rate is plotted to illustrate the consistency of the syngas production rate.

Figure 3-2 shows plots for four parameters associated with the gas turbine. Unit load, stack temperature, percent syngas in the turbine fuel, and percent oxygen have been plotted to illustrate the stability during the test periods. These turbine parameters were generally within $\pm 10 \%$ of their mean value, with the exception of a spike on November 11. The cause for this spike is unknown, but is most likely due to an instrumental anomaly. Oxygen was the most variable of these parameters, but this variability appears to have had little effect on the combustion performance, as evidenced by the stable stack temperatures throughout the test periods.

\section{Analytical Results by Major Stream}

Data for the feed coal, the emission streams, and combustion byproducts are presented in the following sections. All results are shown as averages along with the $95 \%$ confidence interval $(\mathrm{CI})$. The confidence interval represents the range around the average where the true mean lies with a probability of 95 percent. For example, from Table 3-1, there is a $95 \%$ probability that the true raw coal arsenic concentration was between 0.91 and $1.05 \mu \mathrm{g} / \mathrm{g}$. 


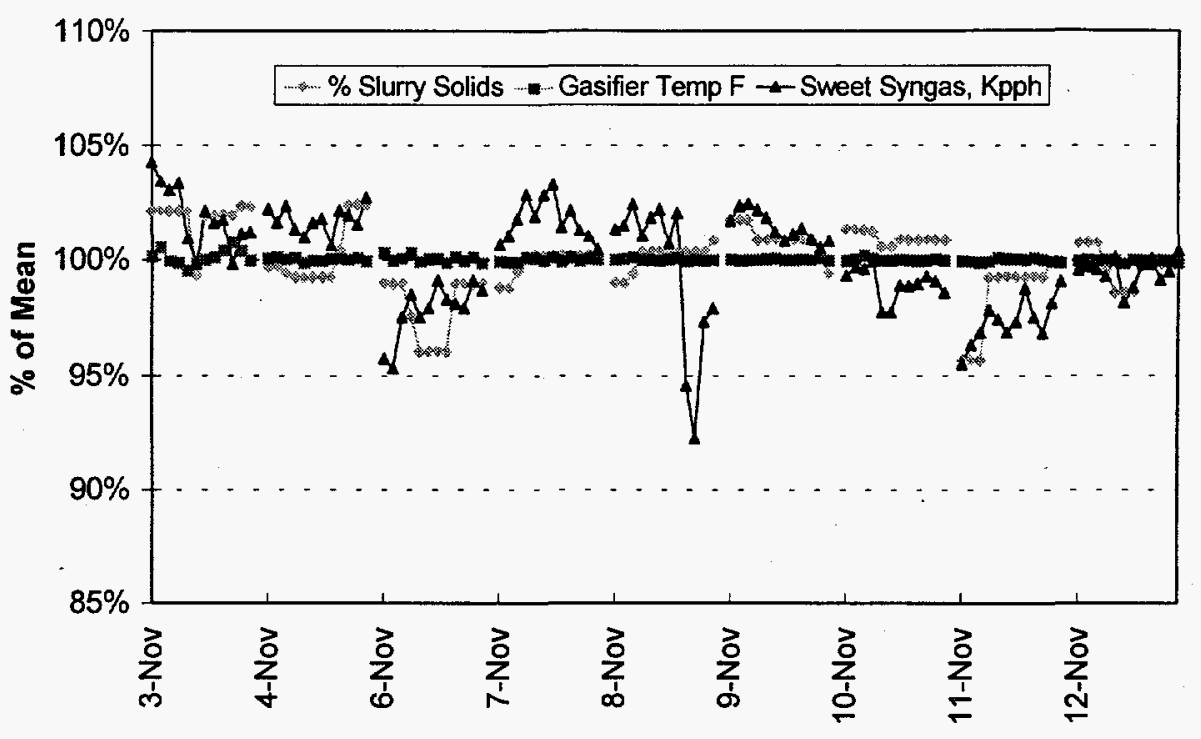

Figure 3-1

Process Parameters for the Gasification System

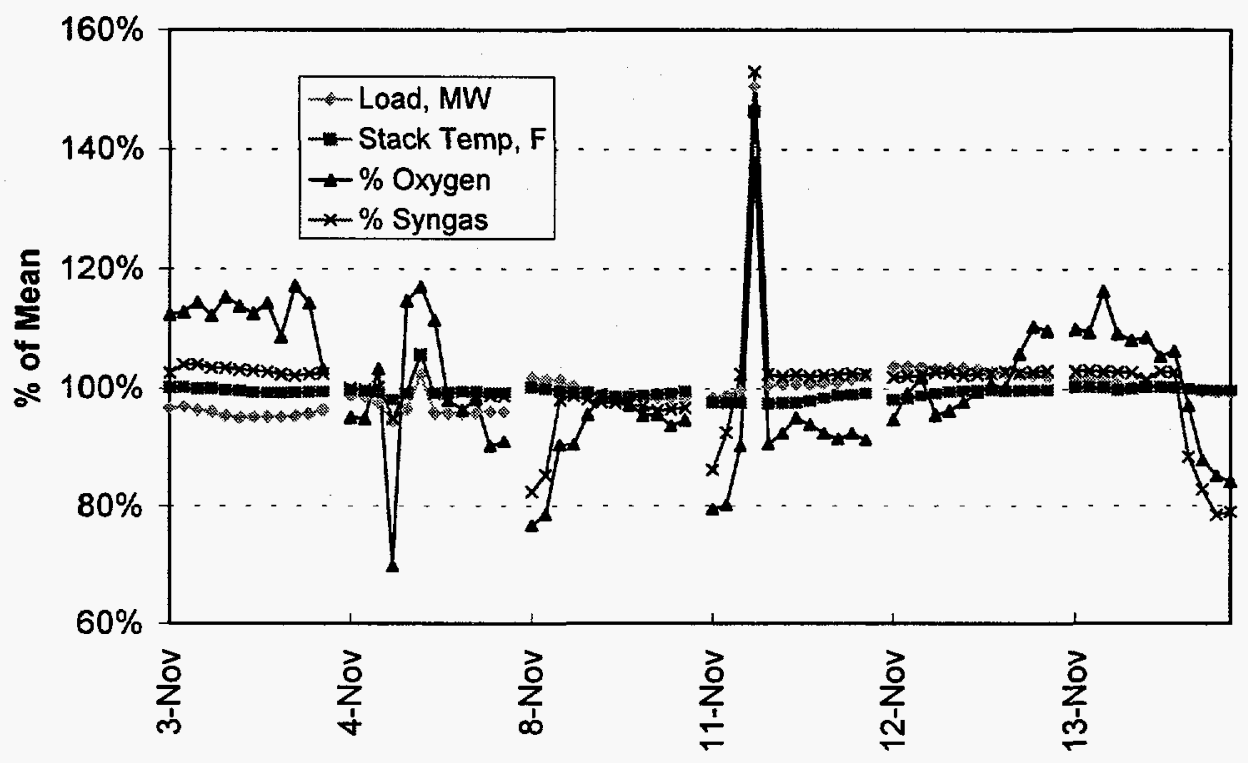

Figure 3-2

Process Parameters for the Gas Turbine 


\section{Coal}

Coal analyses are shown in Table 3-1 for the raw coal as well as the primary and secondary slurry feed streams. All of the results are on a dry-coal basis. The raw coal is slurried with water to form the primary and secondary feed streams. Char, recycled from the venturi scrubber, is also added to the secondary slurry feed stream. The raw coal and the primary slurry feed analyses are very similar. Since the secondary slurry feed stream contains recycled char from the venturi scrubber, the analytical results for this stream may vary considerably from the raw coal and primary slurry feed stream. This is especially the case for certain volatile elements (antimony, arsenic, cadmium, fluorine, and lead) that are enriched in the recycled char and are clearly evident in the secondary slurry feed analysis. The overall quality of the coal data is considered good and permits a good estimate for the mass balance input stream.

\section{Emitted Gas Streams}

The two gaseous emission sources from the LGTI process are the turbine and incinerator stacks. The analytical results for these streams are presented in Table 3-2. The data are presented as mean total values for the elements of interest (i.e., both vapor and solid phases) along with the $95 \%$ confidence interval. Several compounds are present at higher concentrations in the incinerator stack gases. However, the gas flow and hence mass emissions are higher from the turbine. This is illustrated in Figure 3-3 and Figure 3-4. Figure 3-3 shows a comparison of the substance concentrations in the turbine and incinerator stacks. This same information is shown in Figure 3-4 on a mass flow basis, which indicates the relative partitioning of these elements within the process. These two figures provide indirect insight into the performance of the Selectamine $^{\mathrm{TM}}$ and Selectox ${ }^{\mathrm{TM}}$ units with respect to trace elements. Note that the concentration of most substances are comparable in both gas streams, and are very low (1-2 $\mu \mathrm{g} / \mathrm{Nm}^{3}$ ). Also, the air intake to the gas turbine (another possible source of trace elements) was not tested during this program.

Manganese and mercury are present at significantly higher levels in the incinerator stack. The manganese concentration is believed to be erroneous because one of the three test runs had a high impinger concentration of manganese relative to the other two runs. The potassium permanganate solution used to capture mercury in the Method 29 sampling train could have contaminated the nitric acid impinger used for the manganese measurement. On the other hand, the high mercury level in the incinerator stack is believed to be accurate, and may be explained by the formation of mercuric sulfide, which would be removed by the methyl diethanol amine (MDEA) in the Selectamine ${ }^{\mathrm{TM}}$ unit. During the MDEA regeneration, the mercury would be desorbed into the acid gas stream going to the Selectox ${ }^{\mathrm{TM}}$ unit. The volatile mercury would pass through the Selectox ${ }^{\mathrm{TM}}$ system, exit in the tail gas, and be emitted in the incinerator stack gas. 
Table 3-1

Solid Feed Stream Characteristics

\begin{tabular}{|c|c|c|c|c|c|c|}
\hline \multirow[b]{2}{*}{ Analyte } & \multicolumn{2}{|c|}{$\begin{array}{l}\text { Raw Coal } \\
\text { (1a) }\end{array}$} & \multicolumn{2}{|c|}{$\begin{array}{l}\text { Primary Slurry } \\
\text { Feed }\left(1_{p}\right)\end{array}$} & \multicolumn{2}{|c|}{$\begin{array}{l}\text { Secondary Slurry } \\
\text { Feed }\left(1_{s}\right)\end{array}$} \\
\hline & Average & $95 \% \mathrm{Cl}$ & Average & $95 \% \mathrm{Cl}$ & Average & $95 \% \mathrm{Cl}$ \\
\hline \multicolumn{7}{|c|}{ Ultimate/Proximate Parameters } \\
\hline Moisture (Wt. \%) & 29 & 0.24 & 45 & 0.30 & 48 & 0.44 \\
\hline \% Solids (Wt. \%) & - & - & 55 & 0.30 & 52 & 0.44 \\
\hline Ash (Wt. \%) & 6.7 & 0.30 & 6.4 & 0.08 & 7.7 & 0.15 \\
\hline Carbon (Wt. \% ) & 70 & 0.37 & 69 & 0.43 & 69 & 0.31 \\
\hline Hydrogen (Wt. \%) & 4.6 & 0.08 & 4.8 & 0.09 & 4.7 & 0.07 \\
\hline Nitrogen (Wt. \%) & 0.99 & 0.02 & 1 & 0.02 & 1.1 & 0.06 \\
\hline Sulfur (Wt. \%) & 0.28 & 0.01 & 0.28 & 0.01 & 0.28 & 0.01 \\
\hline $\begin{array}{l}\text { Oxygen (by difference) } \\
\text { (Wt. \%) }\end{array}$ & 17 & 0.39 & 19 & 0.34 & 17 & 0.31 \\
\hline Volatile Matter (Wt. \%) & 46 & 0.34 & 46 & 0.29 & 45 & 0.48 \\
\hline Fixed Carbon (Wt. \% ) & 47 & 0.43 & 48 & 0.32 & 47 & 0.52 \\
\hline $\begin{array}{l}\text { Higher Heating Value } \\
\text { (Btu/lb) }\end{array}$ & 12,000 & 68 & 12,000 & 39 & 12,000 & 46 \\
\hline \multicolumn{7}{|c|}{ Elemental Composition, $\mu \mathrm{g} / \mathrm{g}$} \\
\hline Antimony & 0.12 & 0.023 & 0.10 & 0.031 & 0.43 & 0.047 \\
\hline Arsenic & 0.98 & 0.066 & 0.74 & 0.13 & 2.2 & 0.32 \\
\hline Beryllium & 0.27 & 0.029 & 0.21 & 0.04 & 0.31 & 0.039 \\
\hline Cadmium & 0.1 & 0.035 & 0.074 & 0.016 & 1.8 & 0.87 \\
\hline Chloride & 39 & 5.7 & 43 & 7.0 & 56 & 9.2 \\
\hline Chromium & 4.7 & 2.1 & 3.3 & 1.4 & 5.2 & 1.9 \\
\hline Cobalt & 1.9 & 0.11 & 1.5 & 0.27 & 2.2 & 0.15 \\
\hline Fluoride & 76 & 27 & 45 & 5.0 & 260 & 45 \\
\hline Lead & 1.3 & 0.20 & 0.85 & 0.16 & 8.3 & 2.2 \\
\hline Manganese & 9.9 & 0.62 & 8 & 1.3 & 11.0 & 0.80 \\
\hline Mercury & 0.11 & 0.013 & 0.11 & 0.028 & 0.087 & 0.0086 \\
\hline Nickel & 1.6 & 0.56 & 1.8 & 0.51 & 1.1 & 0.37 \\
\hline Selenium & 3.4 & 2.6 & 1.4 & 0.54 & 5 & 1.3 \\
\hline
\end{tabular}


Table 3-2

Emission Stream Characteristics

Analyte Levels

( $\mu \mathrm{g} / \mathrm{Nm}^{3}$, unless specified)

\begin{tabular}{|c|c|c|c|c|}
\hline \multirow{2}{*}{ ( $\mu \mathrm{g} / \mathrm{Nm}^{3}$, unless specified) } & \\
\hline & Average & $95 \% \mathrm{Cl}$ & Average & $95 \% \mathrm{Cl}$ \\
\hline Flow, $\mathrm{Nm}^{3} / \mathrm{hr}$ & $2,180,000$ & - & 19,400 & - \\
\hline Particulate Loading $\mathrm{mg} / \mathrm{Nm}^{3}$ & 3.9 & 3.5 & 141 & 26 \\
\hline Ammonia as $\mathrm{N}$ & 190 & 250 & 750 & 1,400 \\
\hline Antimony & $<2.2$ & $\mathrm{NC}$ & $<2.1$ & $\mathrm{NC}$ \\
\hline Arsenic & 1.2 & 1.1 & 0.69 & 0.90 \\
\hline Beryllium & $<0.012$ & $\mathrm{NC}$ & $<0.012$ & $\mathrm{NC}$ \\
\hline Cadmium & 1.6 & 2.2 & 2.0 & 2.9 \\
\hline Chloride & 420 & 110 & $<2,100$ & NC \\
\hline Chromium & 1.5 & 0.38 & 3.6 & 0.75 \\
\hline Cobalt & 0.32 & 0.34 & 0.38 & 0.22 \\
\hline Cyanide & $<3.2$ & $\mathrm{NC}$ & 5.0 & 7.9 \\
\hline Fluoride & 22 & 13 & 26 & 22 \\
\hline Lead & 1.6 & 0.90 & 2.2 & 2.1 \\
\hline Manganese & 1.7 & 3.8 & 9.6 & 22 \\
\hline Mercury & 0.71 & 0.26 & 28 & 3.3 \\
\hline Nickel & 2.2 & 2.1 & 5.2 & 1.8 \\
\hline Selenium & 1.7 & 0.76 & $<0.21$ & $\mathrm{NC}$ \\
\hline Sulfur dioxide & 13,000 & 6,700 & $7,400,000$ & $1,600,000$ \\
\hline \multicolumn{5}{|c|}{ Volatile Organic Compound Levels } \\
\hline Benzene & 2.5 & 1.0 & 2.5 & 3.0 \\
\hline Toluene & $<0.57$ & $\mathrm{NC}$ & 0.91 & 1.0 \\
\hline Formaldehyde & 9.4 & 4.4 & 0.78 & 0.29 \\
\hline
\end{tabular}

Turbine Stack (13) Incinerator (16) 


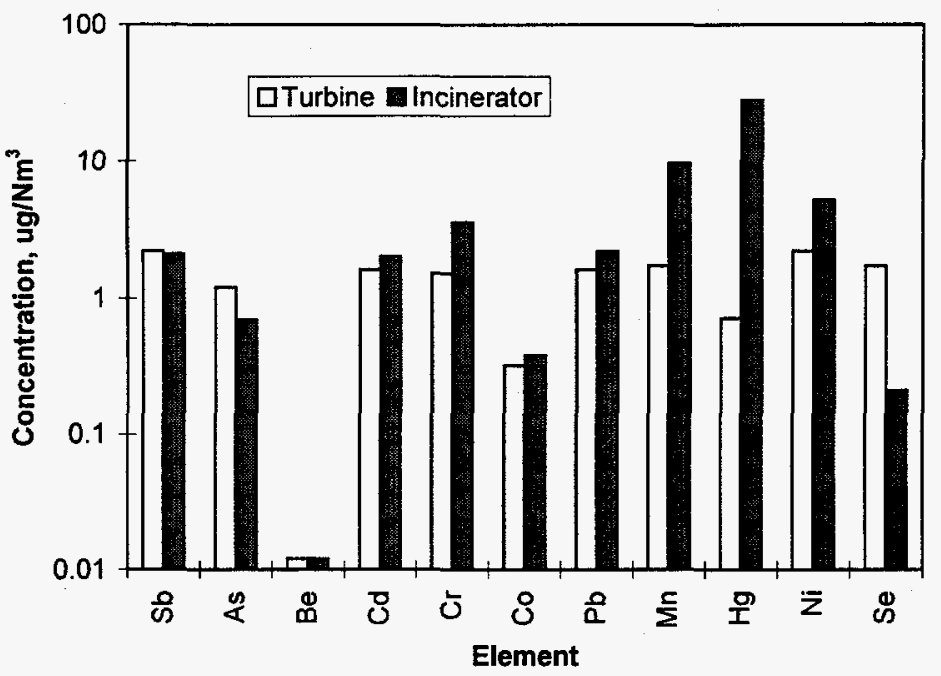

Figure 3-3

Comparison of Emission Stream Elemental Concentrations

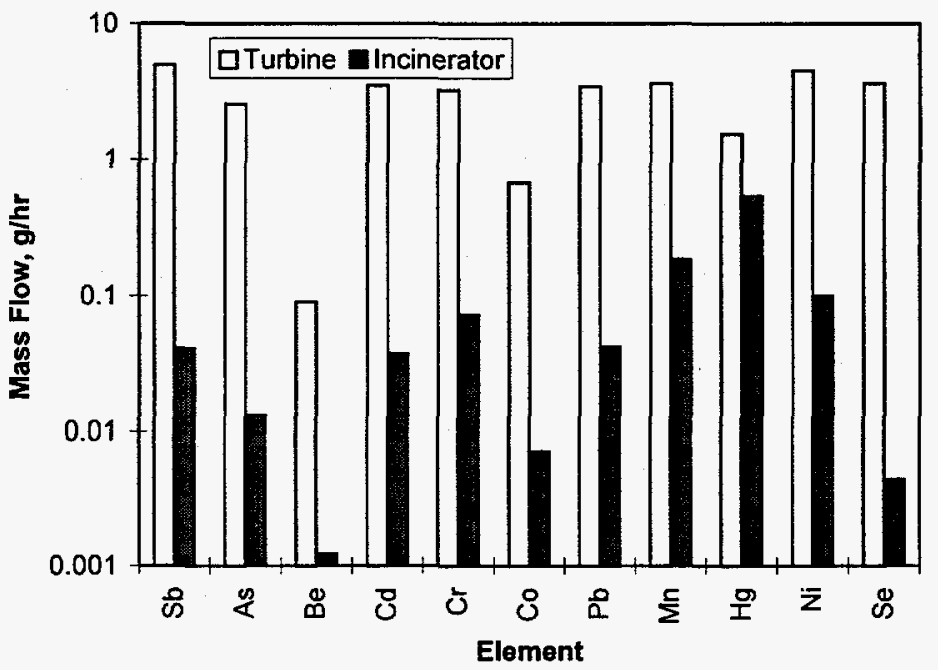

Figure 3-4

Comparison of Emission Streams Elemental Mass Flow 
Most of the trace elements present in the coal are removed in the LGTI process. Figure 3-5 shows the removals of several trace elements across the LGTI system. These data are presented in terms of total air emissions (on a $\mathrm{lb} / 10^{12} \mathrm{Btu}$ of coal basis) as a function of the amounts present in the coal. The major elements, typically associated with the particulate material, are reduced by more than 99.99 percent. Other elements that could be classified as volatile (or semi-volatile) such as arsenic, lead, and selenium are removed by $90-99 \%$ in the process. Only mercury cadmium and antimony were controlled by less than 90 percent. These removals are comparable to those of conventional coal-fired boilers.

\section{Combustion Byproducts}

There are two byproducts from the LGTI process, slag and elemental sulfur. The results of the analyses of these two solid streams is presented in Table 3-3. The slag consists of about $90 \%$ ash and $10 \%$ carbon with minor amounts of the other elements of concern. Most of the trace elements present in the coal leave the process in the slag. The exception are certain "volatile" elements (such as mercury) that migrate downstream in the process.

The recovered sulfur is approximately $99 \%$ pure with only very small trace element amounts. Chromium and selenium were measured above the analytical detection limits, but the multiple test results exhibited high variability. 


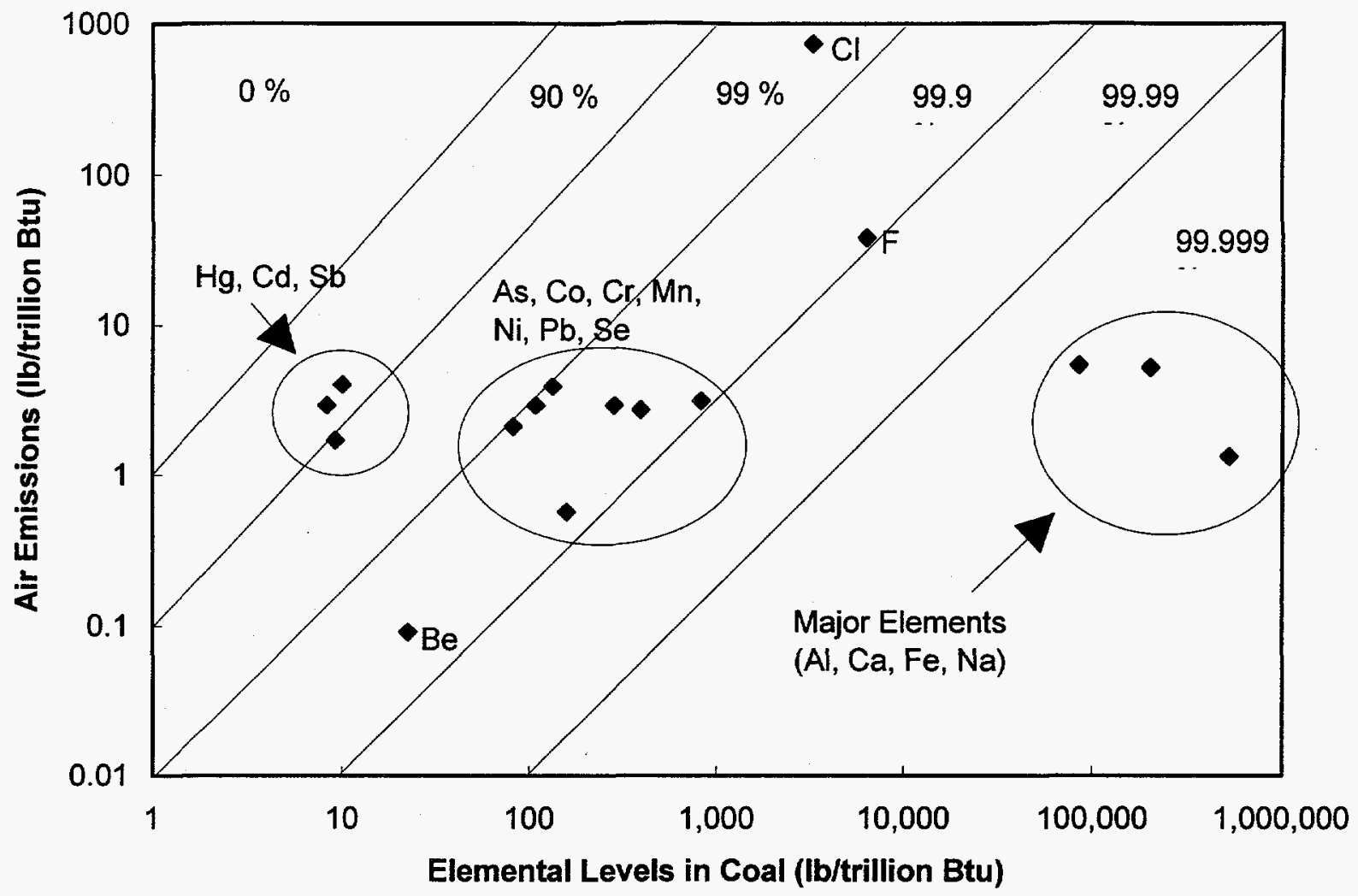

Figure 3-5

Removal of Selected Trace Elements Across the LGTI System 
Table 3-3

Combustion Byproduct Characteristics

Slag (4)

Sulfur (24)

\begin{tabular}{|c|c|c|c|c|}
\hline \multirow[b]{2}{*}{ Analyte } & \\
\hline & Average & $95 \% \mathrm{Cl}$ & Average & $95 \% \mathrm{Cl}$ \\
\hline \multicolumn{5}{|l|}{ Ultimate/Proximate Parameters } \\
\hline $\operatorname{Ash}(\mathrm{Wt} . \%)$ & 89.8 & 5.1 & NA & \\
\hline Carbon (Wt. \%) & 9.5 & 5.2 & $\mathrm{NA}$ & \\
\hline Hydrogen (Wt. \%) & 0.15 & 0.07 & NA & \\
\hline Nitrogen (Wt. \%) & 0.04 & 0.05 & NA & \\
\hline Sulfur (Wt. \%) & 0.03 & 0.02 & 98.7 & 7.0 \\
\hline Oxygen (by difference) (Wt. \%) & 0.27 & 0.19 & NA & \\
\hline \multicolumn{5}{|l|}{ Elemental Composition, $\mu \mathrm{g} / \mathrm{g}$} \\
\hline Antimony & 1.07 & 0.25 & $<3$ & \\
\hline Arsenic & 6 & 0.96 & $<3$ & \\
\hline Beryllium & 3.4 & 0.37 & $<2$ & \\
\hline Cadmium & 0.20 & 0.11 & $<2$ & \\
\hline Chloride & 84 & 56 & NA & \\
\hline Chromium & 76 & 8.3 & 4 & 38 \\
\hline Cobalt & 26 & 2.8 & $<4$ & \\
\hline Fluoride & 200 & 50 & NA & \\
\hline Lead & 3 & 1.1 & $<3$ & \\
\hline Manganese & 130 & 12 & $<2$ & \\
\hline Mercury & 0.020 & 0.006 & 0.095 & 0.19 \\
\hline Nickel & 38 & 4.1 & $<4$ & \\
\hline Selenium & 14 & 5.7 & 24 & 180 \\
\hline
\end{tabular}

NA $=$ Not analyzed 


\section{Aqueous Discharge}

Table 3-4 shows the results for the sweet water discharge from the process. Total suspended solids, chemical oxygen demand (COD), ammonia, formate, and cyanide are the only species that are present at levels greater than $1 \mathrm{mg} / \mathrm{L}$. Of the organic compounds that were detected, most were present in the low $\mu \mathrm{g} / \mathrm{L}$ range. Phenol was the exception at $400 \mu \mathrm{g} / \mathrm{L}$.

Table 3-4

Aqueous Discharge Characteristics

Sweet Water (8)

\begin{tabular}{lcc}
\cline { 2 - 3 } Analyte & Average & $\mathbf{9 5 \%} \mathbf{~ C l}$ \\
\hline Water Quality Parameters (mg/L) & & 0.22 \\
\hline pH & 8.75 & 18 \\
\hline Specific conductance $(\mu \mathrm{mhos})$ & 71.8 & 3.4 \\
\hline Total Suspended Solids & 1.9 & 3.9 \\
\hline Chemical Oxygen Demand & 53 & \\
\hline Elemental Composition (mg/L) & & 3.6 \\
\hline Ammonia as N & 7.3 & $\mathrm{NC}$ \\
\hline Antimony & $<0.076$ & 0.0024 \\
\hline Arsenic & 0.0038 & 0.07 \\
\hline Barium & 0.53 & 0.0013 \\
\hline Beryllium & 0.0006 & 0.051 \\
\hline Boron & 0.039 & 0.0024 \\
\hline Cadmium & 0.005 & 0.15 \\
\hline Chloride & 0.88 & 0.003 \\
\hline Chromium & 0.0087 & $\mathrm{NC}$ \\
\hline Cobalt & $<0.004$ & 0.0044 \\
\hline Copper & 0.015 & 0.1 \\
\hline Cyanide, amenable & 0.035 & 1.2 \\
\hline Cyanide, total & 1.5 & 0.7 \\
\hline Fluoride & 1.8 & 0.41 \\
\hline Formate & 3.2 & \\
\hline & & \\
\hline
\end{tabular}


Table 3-4

Aqueous Discharge Characteristics

Sweet Water (8)

\begin{tabular}{lcc} 
Analyte & Average & $\mathbf{9 5 \%} \mathbf{C l}$ \\
\hline Lead & 0.33 & 0.25 \\
\hline Manganese & 0.0024 & 0.0034 \\
\hline Mercury & $<0.00003$ & $\mathrm{NC}$ \\
\hline Molybdenum & 0.011 & 0.0051 \\
\hline Nickel & 0.022 & 0.042 \\
\hline Phosphate, total (as P) & 0.26 & 0.1 \\
\hline Selenium & 0.032 & 0.02 \\
\hline Sulfate & $<0.047$ & $\mathrm{NC}$ \\
\hline Thiocyanate & 0.82 & 0.72 \\
\hline Volatile Organic Compound Levels, $\mu \mathrm{g} / \mathrm{L}$ & & \\
\hline 1,4-Bromofluorobenzene & 46 & 1.2 \\
\hline Acetone & 5.2 & 3.2 \\
\hline Benzene & $<0.46$ & $\mathrm{NC}$ \\
\hline Methylene chloride & $<3$ & $\mathrm{NC}$ \\
\hline Semivolatile Organic Compound Levels, $\mu \mathrm{g} / \mathrm{L}$ & & \\
\hline 2,4,6-Tribromophenol & 160 & 32 \\
\hline 2-Fluorobiphenyl & 61 & 15 \\
\hline 2-Fluorophenol & 160 & 33 \\
\hline 4-Methylphenol/3-Methylphenol & 0.49 & 1.1 \\
\hline Benzoic acid & 9.2 & 26 \\
\hline Fluoranthene & 2.6 & 1.1 \\
\hline Phenol & 400 & 5.6 \\
\hline Pyrene & 11 & \\
\hline
\end{tabular}




\section{Emission Estimates}

Emission factors, expressed as pounds emitted per $10^{12}$ Btu of heat input to the entire plant (coal and natural gas), were calculated for the combined incinerator and turbine exhaust streams. Emission factors provide a common basis for a comparison of emissions from different processes. However, since an IGCC process can be as much as $15 \%$ more thermally efficient, the emissions, if expressed as $\mathrm{lb} / \mathrm{MW}$, would be $15 \%$ less for an IGCC system as compared to a conventional coal-fired boiler.

The emission rates and emission factors for LGTI are presented in Table 3-5. In Figure 36, these emission factors are compared to those from Plant Yates (a DOE Phase I pulverized-coal site with an ESP and FGD system). This graph shows that in general, the emissions from the LGTI facility are comparable to a well controlled pulverized coal-fired process. [Note, this graph is presented to provide an overall comparison of the order of magnitude of emissions from the two processes. These two units were not burning the same coal, so a direct comparison is not possible. In addition, natural gas was co-fired with the syngas in the LGTI turbines.]

\section{Mass Balances}

Mass balances were calculated for the major process subsystems, as well as around the entire IGCC process as a QA check on the reasonableness of the data. Material balances for some of the internal subsystems support the concern for a lack of proven sampling techniques for reduced gas matrices since many of the elemental balances did not meet the closure objectives of 70-130 percent. Material balances calculated around the entire plant were much better, with $72 \%$ of the measured elements meeting the material balance closure objectives. For the overall plant balances compositional data from reduced gas matrices were not required.

From a QA perspective, the fact that the material balance closure data quality objectives were met by a majority of the elemental measurements around the entire plant increases the confidence in the data. Table 3-6 presents data for the major elemental flows around the LGTI unit. Elements in the table that did not meet the minimum closure objectives include, chloride, fluoride, lead, arsenic, mercury, and selenium. These elements are volatile and typically do not concentrate in the slag. These elements could be accumulating in the Selectamine ${ }^{\mathrm{TM}}$ solvent, but no trace element analysis was done on this stream due to the regeneration of the solvent being performed during the middle of the testing. Nickel has a high closure, but the refractory in the gasifier contains nickel, so a higher mass flow in the slag is not unexpected. The good closure for the major elements indicates the stream flow rates are correct and that analytical sample preparation methods completely dissolved the sample solids. 
Table 3-5

Emission Factors for Selected Substances

Combined Incinerator and Turbine Stack Emissions

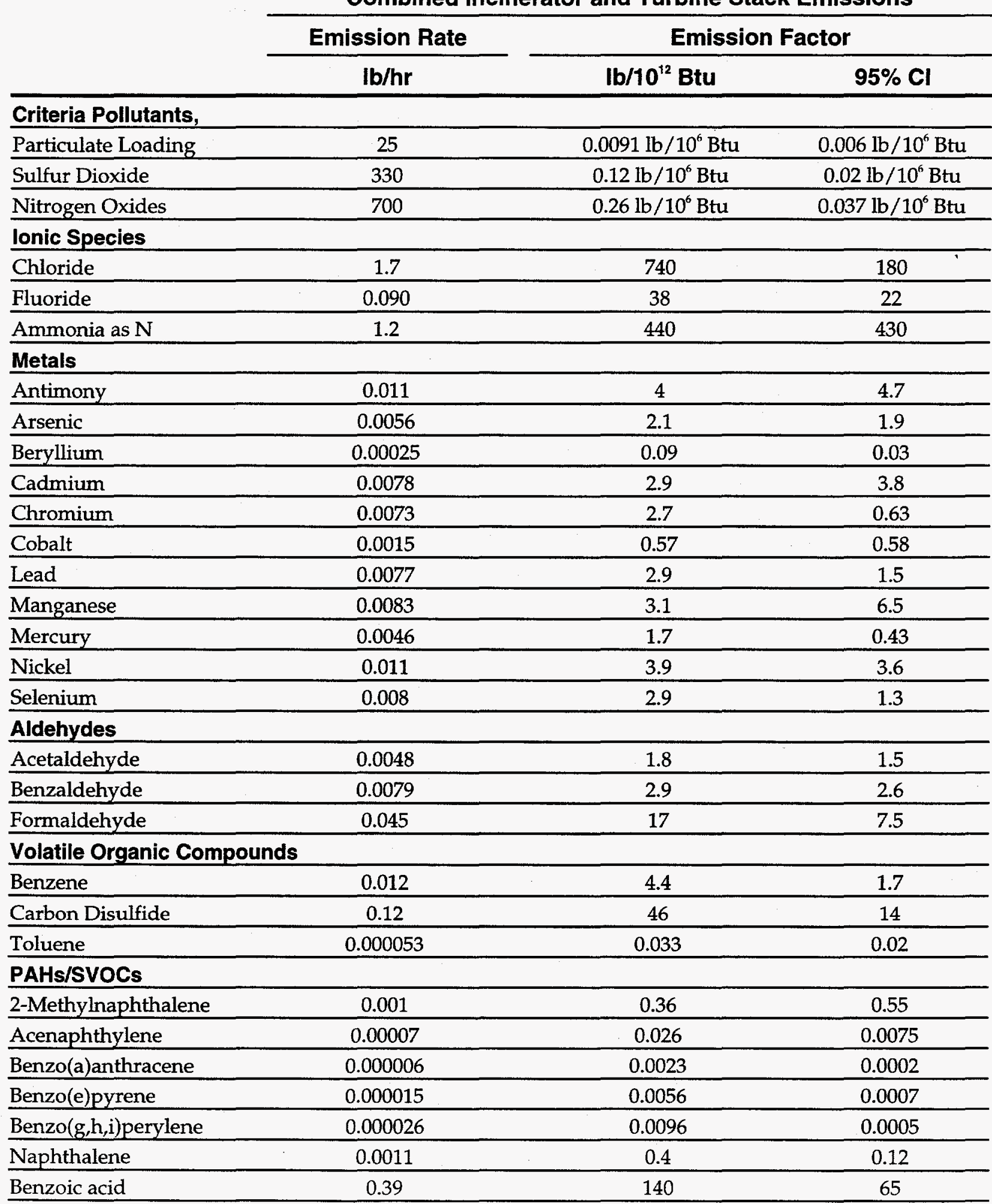




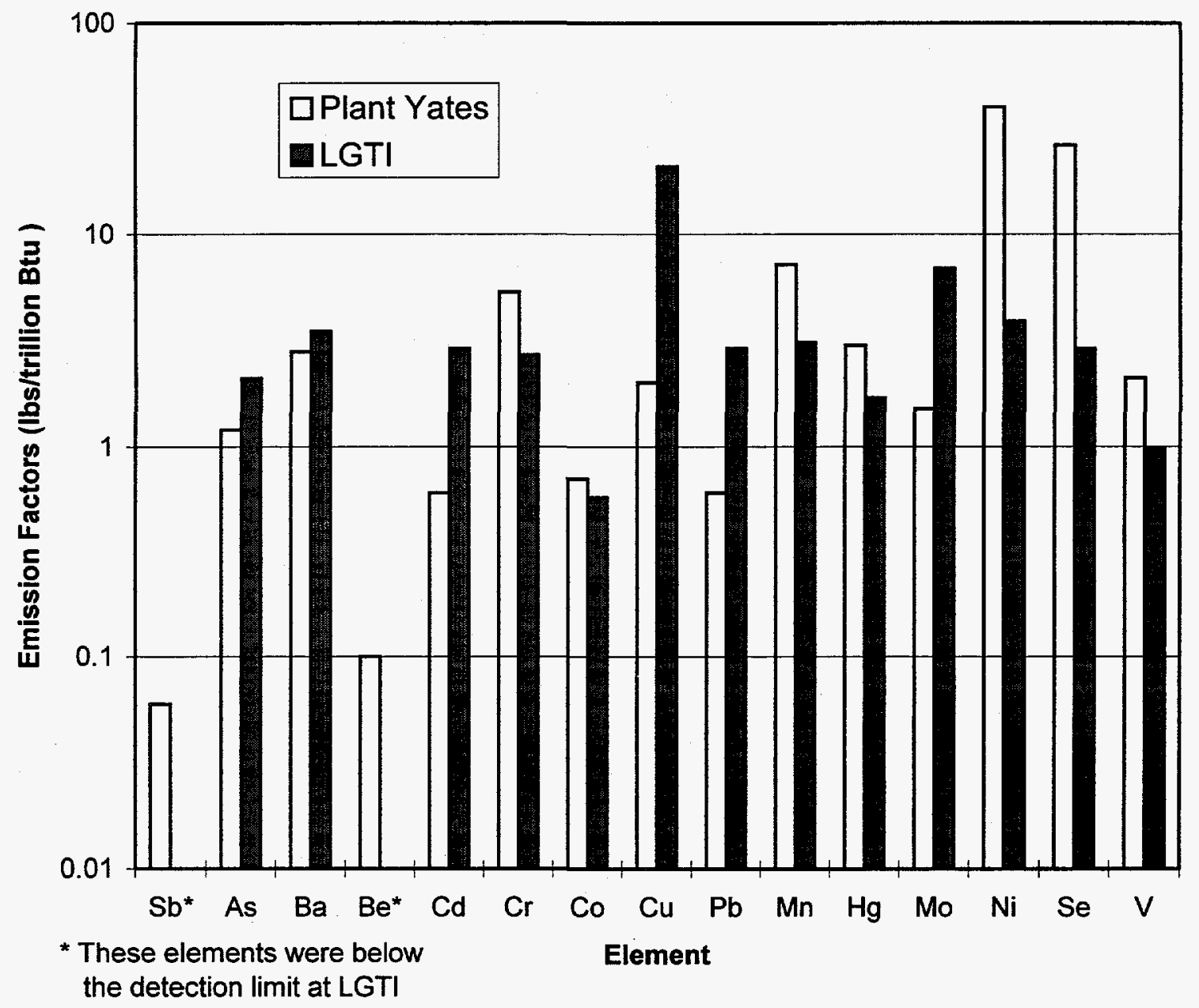

Figure 3-6

Elemental Emission Factor Comparison of LGTI to Conventional Boiler with ESP and FGD Systems (Plant Yates) 
Table 3-6

Selected Elemental Flows Around the LGTI Process

\begin{tabular}{|c|c|c|c|c|c|}
\hline \multirow[b]{2}{*}{ Analyte } & \multirow{2}{*}{$\frac{\text { Input }^{a}}{\text { Coal Feed }}$} & \multicolumn{3}{|c|}{ Output ${ }^{a}$} & \multirow[b]{2}{*}{$\%$ Closure } \\
\hline & & Slag & Incinerator & Gas Turbine & \\
\hline Antimony & 0.016 & 0.011 & 0.00009 & $<0.011$ & $69-138$ \\
\hline Chloride & 5.3 & 0.83 & 0.09 & 2.0 & 57 \\
\hline Fluoride & 10 & 2.0 & 0.0012 & 0.1 & 22 \\
\hline Arsenic & 0.13 & 0.059 & 0.000029 & 0.0056 & 50 \\
\hline Beryllium & 0.037 & 0.034 & 0.0000027 & $<0.00025$ & 95 \\
\hline Cadmium & 0.014 & 0.0020 & 0.000083 & 0.0077 & 78 \\
\hline Chromium & 0.64 & 0.76 & 0.00016 & 0.0071 & 120 \\
\hline Cobalt & 0.26 & 0.26 & 0.000016 & 0.0015 & 101 \\
\hline Copper & 1.6 & 1.5 & 0.00011 & 0.040 & 100 \\
\hline Lead & 0.18 & 0.030 & 0.000093 & 0.0076 & 37 \\
\hline Manganese & 1.3 & 1.3 & 0.00041 & 0.0080 & 99 \\
\hline Mercury & 0.015 & 0.00020 & 0.0012 & 0.0034 & 33 \\
\hline Molybdenum & 0.074 & 0.075 & 0.00022 & 0.018 & 134 \\
\hline Nickel & 0.21 & 0.38 & 0.00022 & 0.010 & 187 \\
\hline Selenium & 0.45 & .013 & 0.0000098 & 0.0080 & 33 \\
\hline \multicolumn{6}{|c|}{ Major Elements } \\
\hline Aluminum & 850 & 900 & $<0.003$ & 0.2 & 107 \\
\hline Calcium & 1,400 & 1,600 & $<0.004$ & 0.6 & 111 \\
\hline Iron & 330 & 370 & 0.009 & 0.4 & 113 \\
\hline Magnesium & 300 & 330 & $<0.001$ & 0.08 & 109 \\
\hline Potassium & 28 & 27 & $<0.01$ & 0.9 & 98 \\
\hline Sulfur ${ }^{b}$ & 380 & 3.0 & 170 & 38 & 119 \\
\hline
\end{tabular}

${ }^{\mathrm{a}}$ All values in $\mathrm{lb} / \mathrm{hr}$.

${ }^{\mathrm{b}}$ Elemental sulfur flow $=240 \mathrm{lb} / \mathrm{hr}$. All other elemental flows were insignificant in the sulfur. 


\section{Trace Substance Partitioning}

The trace substances addressed in this program can be separated into three categories. One category is those substances that are volatile, such as mercury, chloride, and fluoride. These substances are nearly completely vaporized during gasification and carried downstream in the process. Only small portions, if any, are retained in the slag. These substances are transported in the gas stream and may be removed during cooling or scrubbing of the gas. However, they may also remain in the gas phase and ultimately be found in the turbine exhaust. The partitioning of these volatile elements in the LGTI process is shown in Figure 3-7.

A second category includes those trace substances that are considered "semivolatile" such as arsenic, cadmium, lead, and selenium. These elements partition partially into the slag, but are also present in the vapor phase throughout the process. As can be seen from Figure 3-7, some of these elements (cadmium and lead) may partition slightly in the water system, while others remain in the gas steam.

It is not unusual to see material balance closures of less than $100 \%$ for these volatile and semi-volatile trace substances. Many are present in extremely low levels in the coal and there is evidence to suggest that some may accumulate in the Selectamine ${ }^{\mathrm{TM}}$ sulfur removal system. The Selectamine ${ }^{\mathrm{TM}}$ solvent is periodically regenerated to prevent the excessive buildup of heat stable salts. These salts, primarily carboxylic acids, can keep metallic elements in solution by chelation. Additionally, the solvent storage tank is not agitated and a sludge layer accumulates in the bottom. Unfortunately, no samples were taken during the test period that could confirm that the sulfur removal system is also an accumulation point for other trace substances.

A final category contains those trace substances that are non-volatile, including beryllium, chromium, cobalt, manganese, and nickel. Most of these substances partition into the slag and are often not detected in the gas stream or in other parts of the process. The partitioning of these substances at LGTI is shown in Figure 3-8. The higher concentration of both chromium and nickel found in the slag is most likely due to both these materials being present in the refractory material used in the gasifier. A small fraction of these two elements was also measured in the turbine exhaust. Normally one would not consider chromium and nickel as volatile; however, in a reduced gas environment, there is a potential for forming volatile carbonyl compounds of these elements. Turbine blade erosion is also a potential (though very minor) source of emissions.

Figure 3-9 and Figure 3-10 illustrate the partitioning of volatile and non-volatile substances across the IGCC system. Mercury, shown in Figure 3-9, is largely unaccounted for, while nickel, for reasons previously discussed, is enriched in the slag stream. 
Distribution of Volatile and Semivolatile Trace Elements in LGTI Discharge Streams

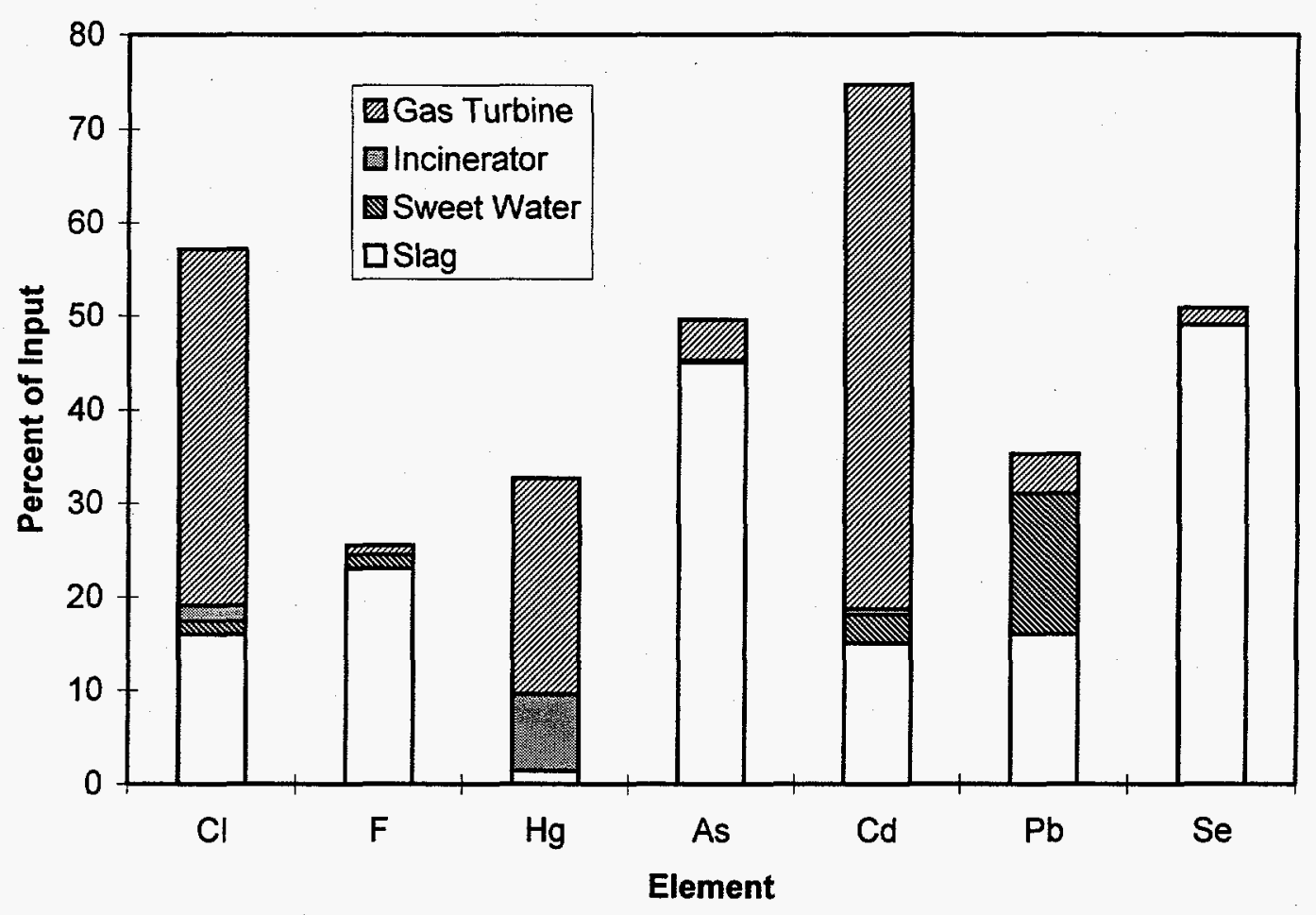

Figure 3-7

Volatile and Semivolatile Trace Substance Distribution 


\section{Distribution of Non-volatile Trace Elements in LGTI Discharge Streams}

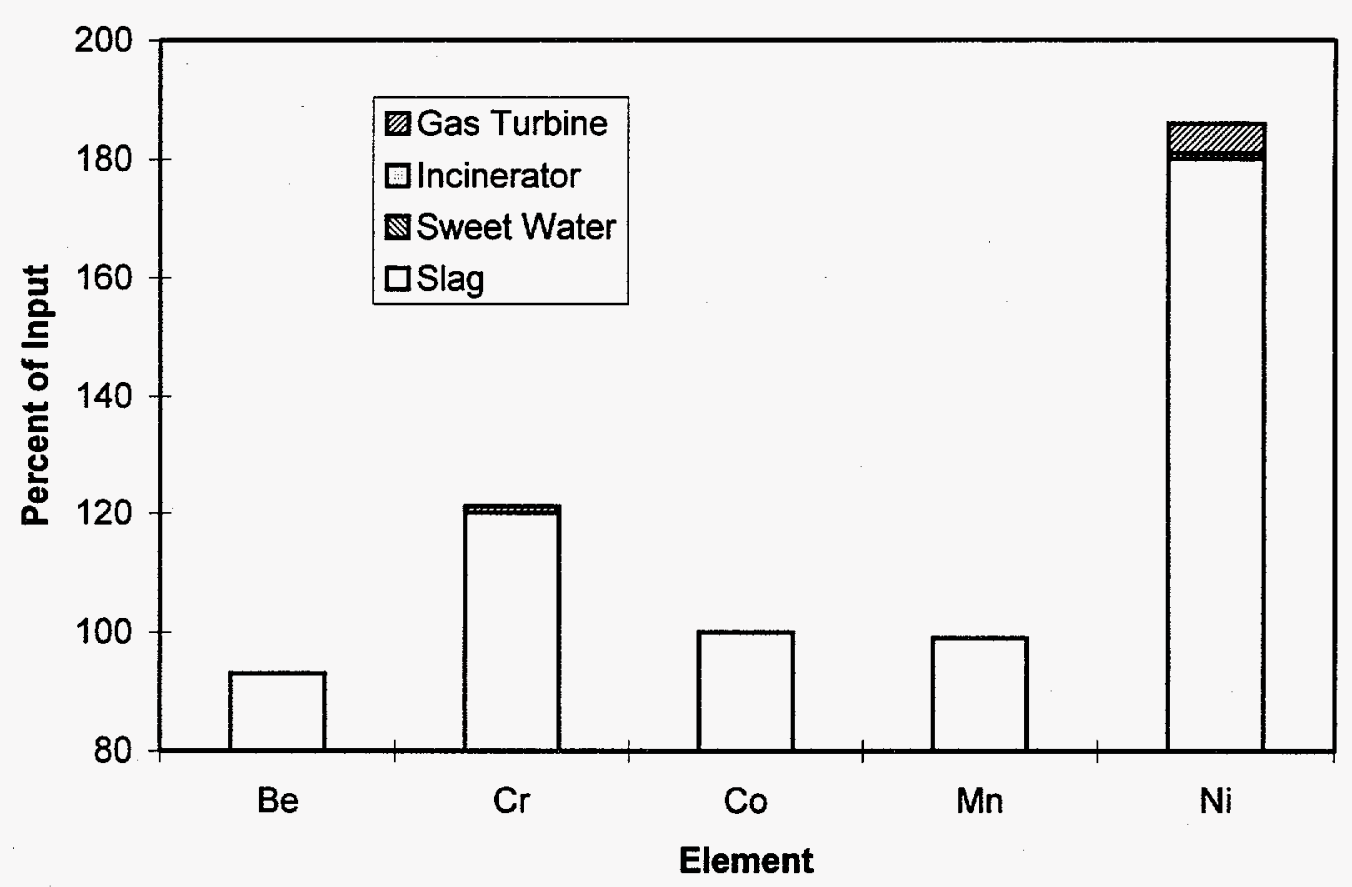

Figure 3-8

Non-Volatile Trace Substance Distribution at LGTI 


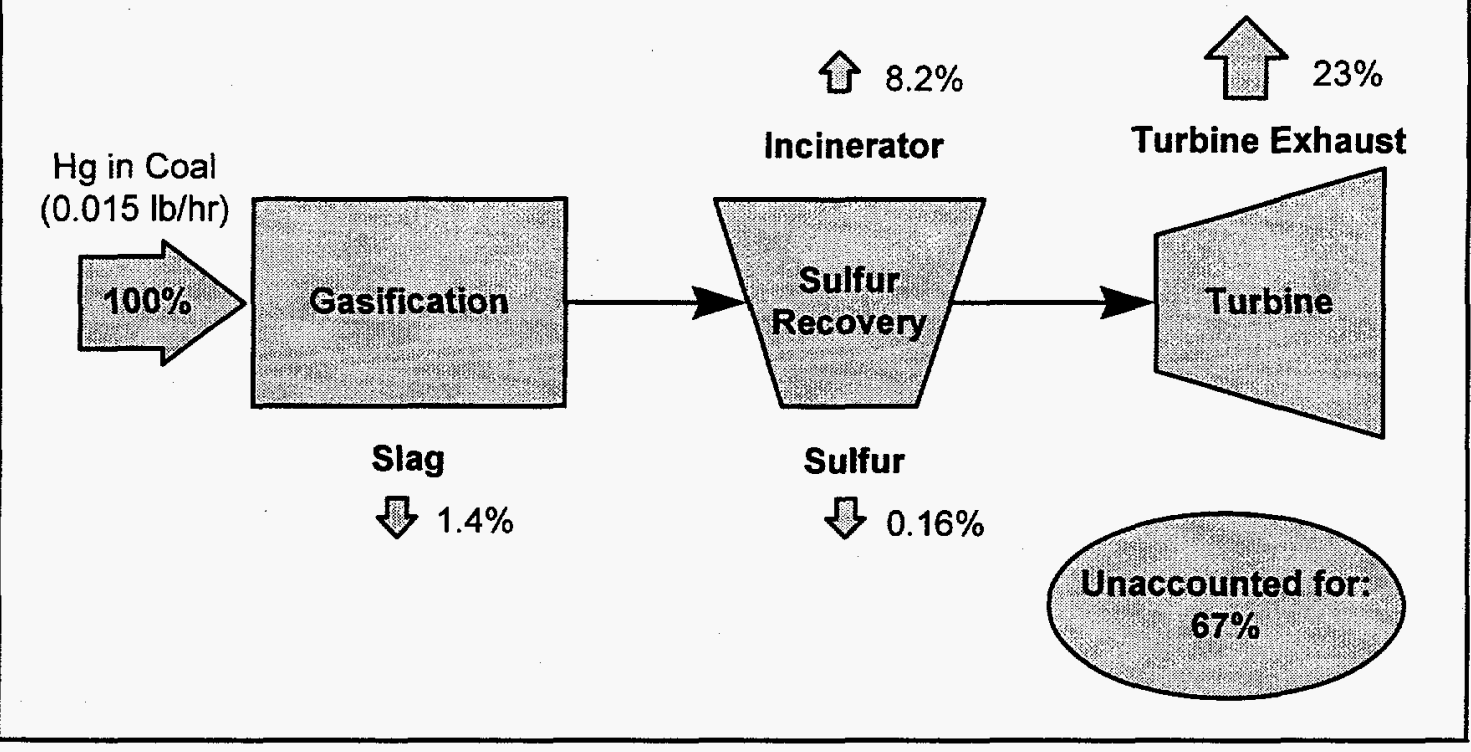

Figure 3-9

Typical Partitioning of a Volatile Substance (Mercury)

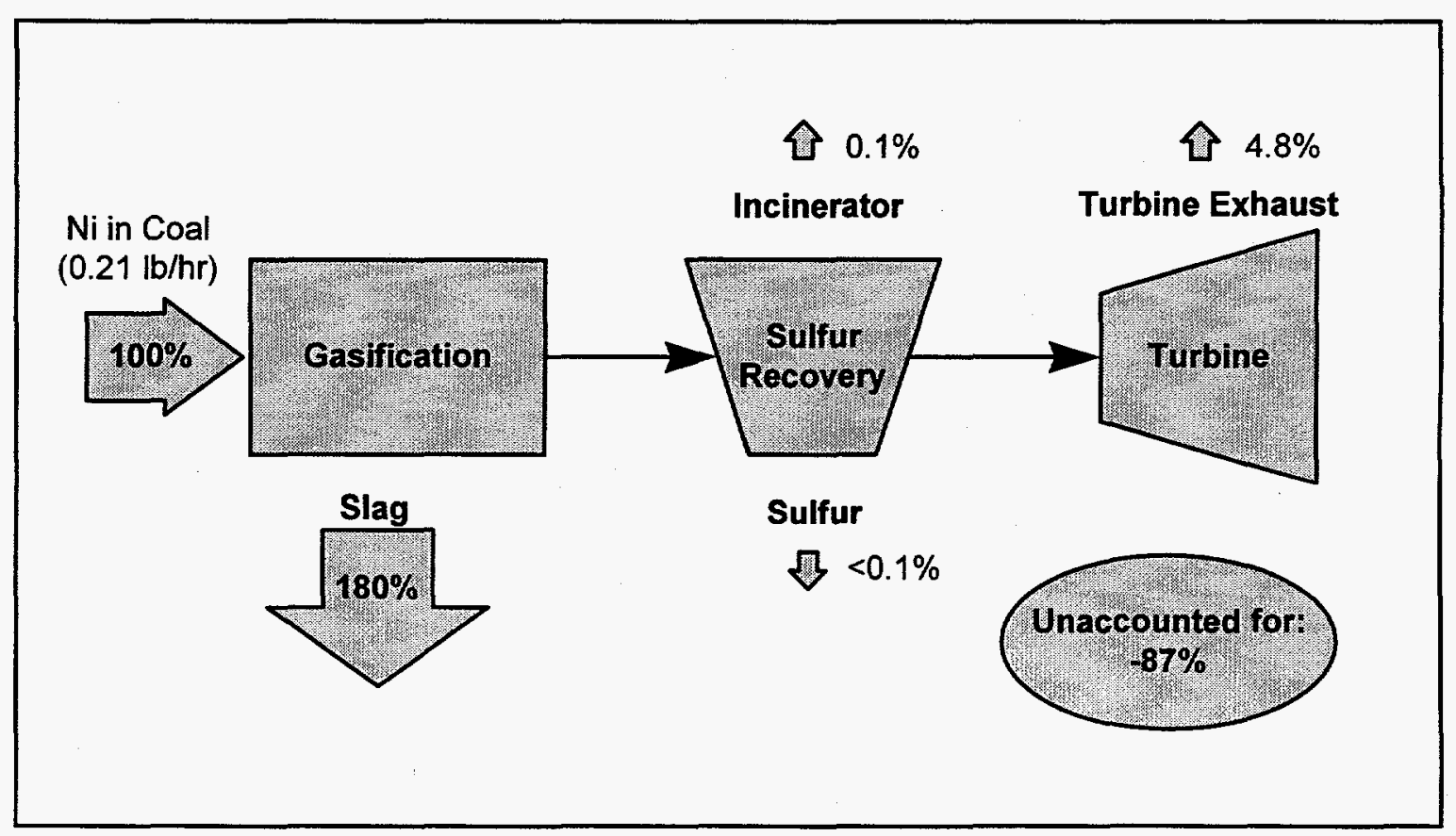

Figure 3-10

Typical Partitioning of a Non-Volatile Substance (Nickel) 
Results

\section{References}

1 A Study of Toxic Emissions from a Coal-Fired Gasification Plant. Radian Corporation. Report DE-AC2293PC93253, U.S. Department of Energy, Pittsburgh Energy Technology Center, Pittsburgh, PA, December 1995. 


\section{4}

\section{SPECIAL INTEREST TOPICS}

Because very few gasification systems are in operation, there have been limited opportunities to sample and analyze their internal process streams. Upon combustion, the emission streams can be accurately quantified using the validated sampling methods available for conventional fossil fuel fired power plants. The reducing nature of the internal process streams of an IGCC process requires modifications for some of the sampling methods to obtain valid results.

The special topics covered in this section apply to the sampling and analysis of trace metals in reduced gas environments. The reason for the focus on trace metals is that standard EPA test methods for volatile organics, semivolatile organics, ammonia, cyanide etc. seem to work fine in a reducing environment. This is not the case with vapor phase trace metal test methods. Trace elements emissions in general and mercury emissions in specific tend to be the key air toxic issues for the utility industry. ${ }^{1}$

The validated method for the collection of trace metals is EPA Method 29, which consists of sampling the gas isokinetically through a heated probe, collecting particulate matter on a filter, and then bubbling the gas through a series of five impingers. The first two impingers contain a mixture of nitric acid and hydrogen peroxide. These impingers are followed by a knockout impinger (to prevent carryover) and two impingers containing a solution of potassium permanganate specifically for the collection of elemental mercury.

For the sampling of only vapor phase metals in the internal process streams, Method 29 was modified by increasing the nitric acid and hydrogen peroxide concentrations. The gas was still filtered, but the filter only served to prevent potential contamination of the impinger solutions due to trace amounts of particulate. In addition, the potassium permanganate impingers were not used, as their oxidizing capacity for mercury collection is rapidly depleted by the hydrogen sulfide that is present in the syngas. Other trace metal sampling techniques involving solid sorbent adsorption and an instrumental technique using a specially modified gas chromatograph were also applied. Even so, some questionable trace metals results were obtained for many of the internal streams. Nevertheless, discovering which method did not work and which procedures showed promise has provided valuable information to DOE and EPRI for future work in this area.

In this section three special topics are discussed that involve the collection of samples in reduced gas matrices. The first is the measurement of mercury in a reduced gas 
atmosphere. Next, the issue of sampling and analyzing for trace elements in a reduced gas matrix will be discussed, followed by a description of a "hot gas" sampling probe that was designed, built and used during this test program.

\section{Mercury Measurements}

Extensive research is currently being done to develop sampling and analytical protocols for the speciation of mercury in flue gas (oxidized gas matrix). Many of the mercury tests that were conducted during this project were done on internal process streams (in a reduced gas matrix), where interferents such as $\mathrm{H}_{2} \mathrm{~S}$ (which are not found in flue gas) were encountered. Reduced species such as $\mathrm{H}_{2} \mathrm{~S}$ complicate the task of acquiring representative mercury samples, as they react with the oxidants in the Method 29 sampling train impingers, degrading the oxidizing/collection efficiency of the sampling method. In an attempt to determine alternative approaches to the collection of mercury, Radian implemented parallel tests during the field program to evaluate the absorbing capacity of several solutions for the collection of mercury. An atomic absorption spectrophotometer (AAS), designed such that the synthesis gas can pass directly through a cold vapor cell allowing for the direct measurement of mercury, was used to monitor the efficiency of these absorbing solutions. A schematic of this system is shown in Figure 4-1. Testing was conducted on both the sweet and sour syngas. In general, sample gas was passed through the impinger train where either:

- All forms of mercury were reduced to the elemental state; or

- Ionic and elemental forms of mercury were selectively retained in the impinger train; or

- Ionic forms were retained while elemental mercury was passed on to the gold amalgamation unit.

Depending upon the configuration, mercury was either allowed to concentrate on the gold trap during sample collection, or it was later purged with argon from the collecting impinger solutions after the introduction of a reducing agent (sodium borohydride). The sample gas was vented through additional scrubbing solutions before being metered with a dry gas meter. After the desired sample volume was delivered, enough argon was passed through the impingers to purge any remaining mercury through the system. A total of nine different combinations of impingers were used and are described in Table 4-1.

Mercury was also sampled by collection / adsorption onto charcoal. The speciallycleaned coconut-based charcoal was placed into pre-cleaned quartz tubes. Samples of the sweet and sour syngas were passed through the tubes. The charcoal tubes were returned to the laboratory and analyzed by digesting the charcoal with nitric acid and then determining mercury by CVAAS (SW7470). ${ }^{2}$ 
The results from these tests were variable and in many cases indicate that both $\mathrm{H}_{2} \mathrm{~S}$ and water can have a significant effect on the sample collection efficiency. In the sour syngas, charcoal appeared to collect mercury more efficiently than the impinger techniques that were tried, and in the sweet syngas, just the opposite was true. Moisture and $\mathrm{H}_{2} \mathrm{~S}$ content are the primary differences in these two gaseous streams.

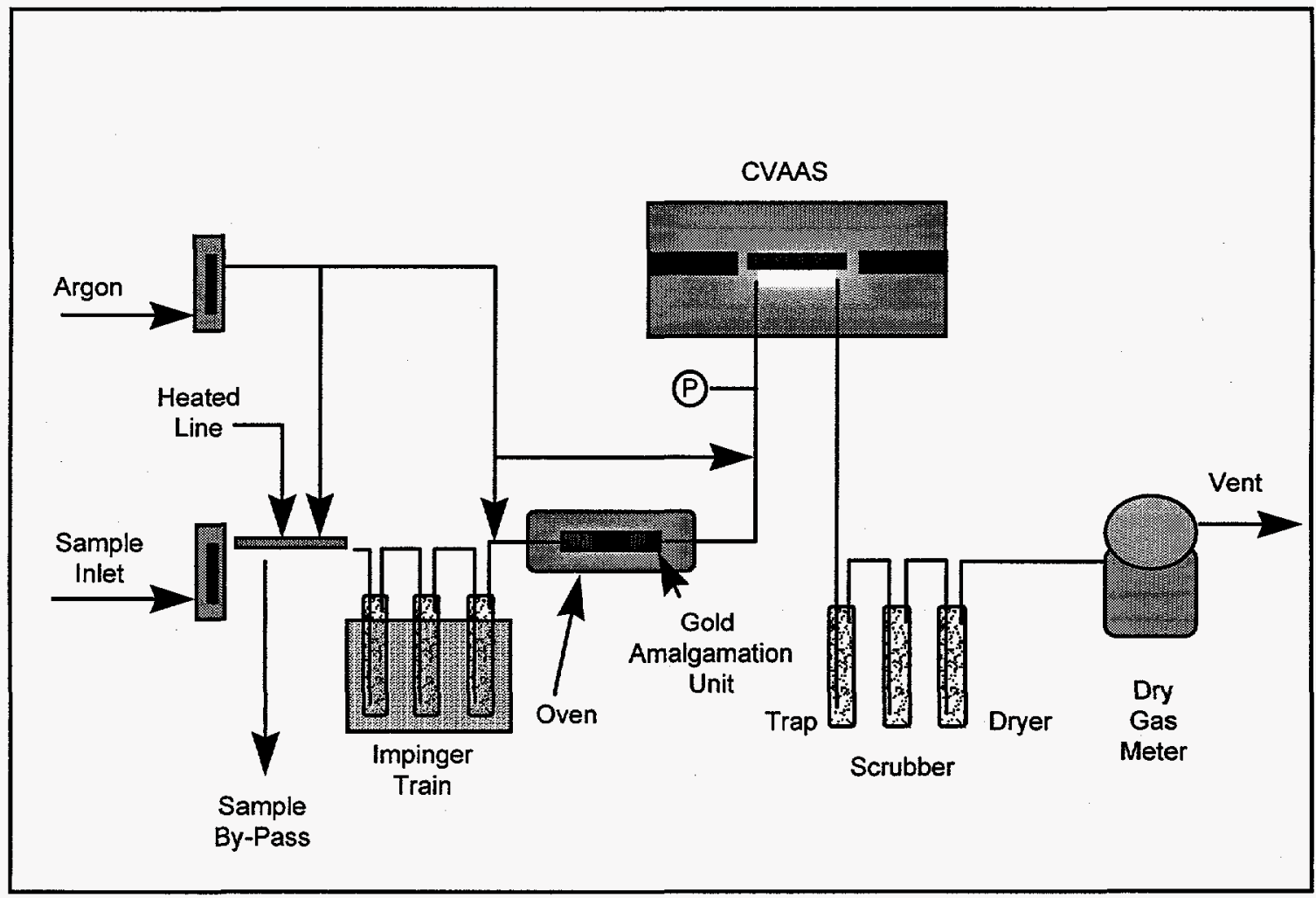

Figure 4-1

Schematic of CVAAS System 
Table 4-1

Gold Amalgamation-CVAAS Impinger Train Configurations

\begin{tabular}{|c|c|c|c|c|c|}
\hline \multirow[b]{2}{*}{$\begin{array}{c}\text { Configuration } \\
\text { No. }\end{array}$} & \multicolumn{4}{|c|}{ Impinger Solutions } & \multirow[b]{2}{*}{ Function } \\
\hline & Impinger 1 & Impinger 2 & Impinger 3 & Impinger 4 & \\
\hline 1 & $50 \mathrm{mM} \mathrm{NaBH}_{4}$ & NA & NA & NA & Total $\mathrm{Hg}$ reduction to $\mathrm{Hg}^{0}$ \\
\hline 2 & $0.1 \mathrm{~N} \mathrm{NaOH}$ & $50 \mathrm{mM} \mathrm{NaBH}_{4}$ & NA & NA & $\begin{array}{l}\text { Remove } \mathrm{H}_{2} \mathrm{~S} \text { prior to total } \\
\mathrm{Hg} \text { reduction to } \mathrm{Hg}^{\circ}\end{array}$ \\
\hline $2 a$ & $2 \mathrm{M} \mathrm{NaOH}$ & $50 \mathrm{mM} \mathrm{NaBH}_{4}$ & NA & NA & $\begin{array}{l}\text { Remove } \mathrm{H}_{2} \mathrm{~S} \text { prior to total } \\
\mathrm{Hg} \text { reduction to } \mathrm{Hg}^{\circ}\end{array}$ \\
\hline 3 & $\begin{array}{l}4 \% \mathrm{H}_{2} \mathrm{O}_{2 /} / \\
5 \% \mathrm{HNO}_{3}\end{array}$ & $0.1 \mathrm{~N} \mathrm{NaOH}$ & cold knockout & $\begin{array}{l}4 \% \mathrm{KMnO}_{4} / 10 \% \\
\mathrm{H}_{2} \mathrm{SO}_{4}\end{array}$ & $\begin{array}{l}\text { Collect ionic and elemental } \\
\mathrm{Hg} \text { separately with } \mathrm{H}_{2} \mathrm{~S} \\
\text { removal }\end{array}$ \\
\hline 4 & $\begin{array}{l}80 \% \text { IPA / 0.1M } \\
\text { DEDTC }^{a}\end{array}$ & $0.1 \mathrm{~N} \mathrm{NaOH}$ & $\begin{array}{c}\text { cold knockout } \\
-\end{array}$ & $\begin{array}{l}4 \% \mathrm{KMnO}_{4} / 10 \% \\
\mathrm{H}_{2} \mathrm{SO}_{4}\end{array}$ & $\begin{array}{l}\text { Collect ionic and elemental } \\
\mathrm{Hg} \text { separately with } \mathrm{H}_{2} \mathrm{~S} \\
\text { removal }\end{array}$ \\
\hline 5 & $\begin{array}{l}80 \% \text { IPA } / 0.1 \mathrm{M} \\
\text { DEDTC }\end{array}$ & $0.1 \mathrm{~N} \mathrm{NaOH}$ & $\begin{array}{l}4 \% \mathrm{KMnO}_{4} / 10 \% \\
\mathrm{H}_{2} \mathrm{SO}_{4}\end{array}$ & NA & $\begin{array}{l}\text { Collect ionic and elemental } \\
\mathrm{Hg} \text { separately with } \mathrm{H}_{2} \mathrm{~S} \\
\text { removal }\end{array}$ \\
\hline 6 & $\begin{array}{l}4 \% \mathrm{H}_{2} \mathrm{O}_{2} / 5 \% \\
\mathrm{HNO}_{3}\end{array}$ & cold knockout & $\begin{array}{l}4 \% \mathrm{KMnO}_{4} / 10 \% \\
\mathrm{H}_{2} \mathrm{SO}_{4}\end{array}$ & NA & $\begin{array}{l}\text { Collect ionic and elemental } \\
\mathrm{Hg} \text { separately without } \mathrm{H}_{2} \mathrm{~S} \\
\text { removal }\end{array}$ \\
\hline 7 & $\begin{array}{l}4 \% \mathrm{H}_{2} \mathrm{O}_{2} / 5 \% \\
\mathrm{HNO}_{3}\end{array}$ & $50 \mathrm{mM} \mathrm{NaBH}_{4}$ & NA & NA & $\begin{array}{l}\text { Collect ionic } \mathrm{Hg} \text { and } \\
\text { reduce penetrated } \mathrm{Hg}\end{array}$ \\
\hline 8 & $\begin{array}{l}80 \% \text { IPA } / 0.1 \mathrm{M} \\
\text { DEDTC }\end{array}$ & $50 \mathrm{mM} \mathrm{NaBH}_{4}$ & NA & NA & $\begin{array}{l}\text { Collect ionic } \mathrm{Hg} \text { and } \\
\text { reduce penetrated } \mathrm{Hg}\end{array}$ \\
\hline 9 & $\begin{array}{l}\mathrm{Sat}^{\prime} \mathrm{d} \mathrm{SnCl} / 0.5 \mathrm{~N} \\
\mathrm{H}_{2} \mathrm{SO}_{4}\end{array}$ & NA & NA & NA & Total $\mathrm{Hg}$ reduction to $\mathrm{Hg}^{0}$ \\
\hline
\end{tabular}

${ }^{a}$ Diethyldithiocarbamic acid 
Based upon the initial results, additional changes were made to EPA Method 29 (see discussion page 4-1) by inserting an impinger containing sodium hydroxide following the nitric acid impingers, then adding the potassium permanganate impingers as per the original method. This configuration was tested in the last test period (Test Period 4) that focused strictly on a hot syngas location upstream of the carbon scrubber. This modification appeared to greatly help in the collection of mercury. Although it was evident that $\mathrm{H}_{2} \mathrm{~S}$ still penetrated the potassium permanganate, mercury collection in the potassium permanganate impingers was greatly enhanced over the early test periods.

The procedures implemented during Test Period 4 did not yield a definitive test method for mercury (nor was the approach designed to do so). However, using a caustic impinger to reduce or eliminate the $\mathrm{H}_{2} \mathrm{~S}$ prior to the potassium permanganate impinger appears to be a promising approach, at least for total mercury measurements. Complete details of the methodologies and results that were obtained under the various test conditions can be found in the comprehensive report. ${ }^{3}$

\section{Trace Elements in Reduced Gas Streams}

To date, all gasification processes have used sulfur removal systems that require the sour gas to be cooled to near ambient temperatures. Following sulfur removal, the sweet fuel gas is then preheated prior to being fired in a gas turbine. The ability to remove $\mathrm{H}_{2} \mathrm{~S}$ from syngas without cooling allows for a substantial increase in overall process efficiency. Since some trace elements are volatile (especially in a reduced gas matrix), it is likely that measurable amounts of these trace elements (relative to the coal concentration) will be present in the hot syngas. Syngas associated with a hot gas cleanup system will not go through a "cold" acid gas absorption process (where there is evidence to suggest that some removal occurs), and, therefore, emissions could be different from those currently attributed to gasification processes. From this perspective, it is important to know:

- If the sample collection technique that is used accounts for all species of the particular element;

- How to accurately sample and analyze for trace elements in reduced gases;

- Whether a hot gas cleanup system affects speciation; and

- If volatile trace elements are removed in a hot gas cleanup system.

As with mercury, it was strongly suspected that Method 29 (modified or not) was not a good method for the collection of other vapor phase trace elements in a reduced gas matrix. During this test effort, additional trace element collection / analytical techniques were tried to provide as much insight as possible as to what may or may not be acceptable approaches for characterizing trace elements in a reduced gas matrix. Three collection / analytical methods were tried on the sweet and sour syngas. First, the 
nitric acid/hydrogen peroxide concentrations of Radian's modified EPA Method 29 were increased to 10 and $30 \%$, respectively, in an effort to increase the oxidizing capacity of the solution. Second, gas samples were collected / adsorbed onto specially cleaned charcoal, as described in the previous section for mercury. Third, the sweet and sour syngas streams were analyzed by a vapor phase atomic absorption spectrophotometer (VPAAS). The AAS was modified to accept syngas for a portion of the fuel gas going to the nebulizer mixing chamber and flame. In the flame, vapor-phase compounds are atomized and absorb light energy from an element-specific light source just like aqueous samples in conventional AAS. Seven elements, (arsenic, cadmium, nickel, chromium, lead, selenium, and zinc) were analyzed using this technique. A schematic of the VPAAS system is shown in Figure 4-2.

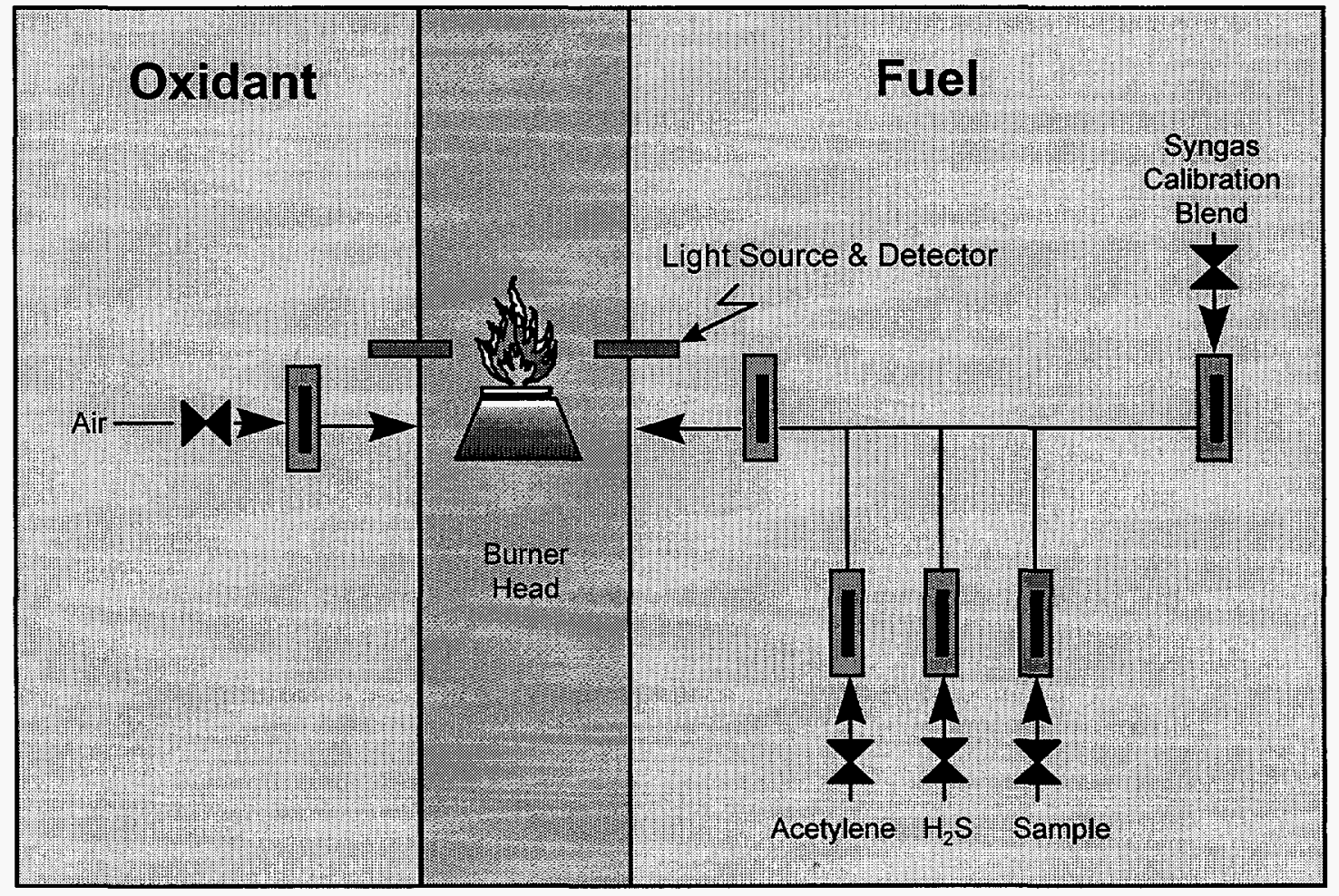

Figure 4-2

Schematic of On-line AAS

The results from these three methods varied considerably for most of the metals that were measured. The results using the modification to EPA Method 29 were consistently low or not detected As discussed earlier, the presence of $\mathrm{H}_{2} \mathrm{~S}$ and the moisture content of the gas stream seemed to have an effect on the collection of trace elements using charcoal. The results obtained using the VPAAS system generally represented the highest concentrations obtained by any of the methods. This is illustrated in Figure 4-3 
where the average concentrations of four metals determined by the three different techniques are compared. Intuitively, one might expect the VPAAS system to yield the highest results as this method is not compound specific, and should produce a total elemental concentration. This is the case for the four elements shown in Figure 4-3. Until further study can be done with the charcoal collection technique, it is not known if, for a given element, all forms of the element are collected with this method. As can be seen from the graph, EPA Method 29 (modified) produced the lowest results of any of the collection techniques.

\section{Sour Syngas}

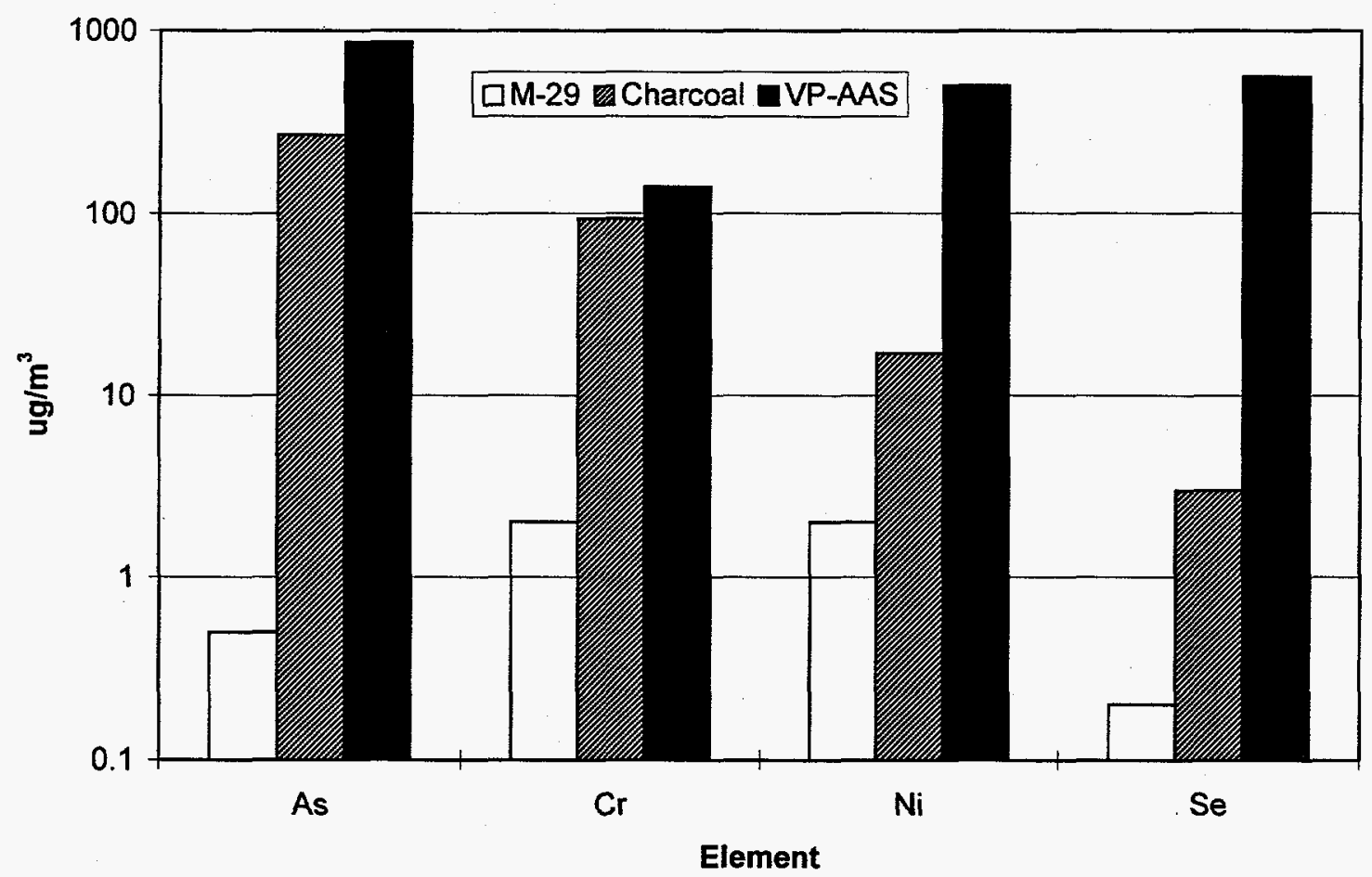

Figure 4-3

Trace Element Methods Comparison

\section{Hot Gas Testing}

Radian designed and fabricated a sampling system specifically for the characterization of the hot synthesis gas upstream of the venturi scrubber. The temperature and pressure at this location were approximately $900^{\circ} \mathrm{F}$ and $350 \mathrm{psig}$ respectively. The sampling system was designed to obtain a representative sample of the hot gas and particulate. This required that the particulate and vapor phases be separated at process conditions in order to avoid any changes that may occur to either phase as a result of cooling or pressure reduction. This was accomplished by filtering the gas "in-stack." The probe 
was retractable, in order to retrieve the collected particulate material. The sample was cooled and recovered in a non-reactive nitrogen atmosphere. The probe was inserted and retrieved via a trolley and winch system. The packing gland was designed such that only nitrogen would leak through seals and not flammable, toxic syngas. The sampling system was designed for a syngas temperature of $1,200^{\circ} \mathrm{F}$, and provisions were made for lowering the gas dew point by dilution with nitrogen. The sampling system worked well, and the only problem encountered was that the syngas temperature was lower than anticipated. Consequently, the gas temperature fell below the dew point before dilution nitrogen could be injected into the gas steam and some condensation occurred within the probe during the testing.

With the exception of the condensation that occurred during sample collection, the collected samples were judged to be representative of the process. The major problems encountered had to do with the sample collection techniques that were used. For lack of alternative methods, EPA Method 29 (modified) and charcoal tubes were used for sample collection. (The VPAAS was not used during this test period.) Although results were again very scattered, arsenic, mercury and selenium were all detected using the charcoal tube collection technique. (Chromium and nickel were also detected, but since they are each potential contamination products from the sampling system materials of construction, their presence and measured concentrations are questionable.)

\section{References}

1 L. Levin, et al. "Electric Utility Trace Substances Synthesis Report", Volumes 1-4, Electric Power Research Institute, Palo Alto CA, TR-104614, November 1994.

2 U.S. Environmental Protection Agency, Office of Solid Waste. "Method 7470: Mercury in Liquid Waste (Manual Cold-Vapor Technique)," Test Methods for Evaluating Solid Waste. SW-846, $3^{\text {rd }}$ ed. Washington, DC (November 1986)

3 A Study of Toxic Emissions from a Coal-Fired Gasification Plant. Radian Corporation. Report DE-AC2293PC93253, U.S. Department of Energy, Pittsburgh Energy Technology Center, Pittsburgh, PA, December 1995. 


\section{GLOSSARY}

\begin{tabular}{|c|c|}
\hline AAS & Atomic absorption spectrophotometry \\
\hline Btu & British thermal unit \\
\hline $\mathrm{CI}$ & Confidence interval \\
\hline COD & Chemical oxygen demand \\
\hline CVAAS & Cold vapor atomic absorption spectrophotometry \\
\hline CVAFS & Cold vapor atomic fluorescence spectrophotometry \\
\hline DL & Detection limit \\
\hline dscfm & Dry standard cubic feet per minute $\left(1 \mathrm{~atm}, 6^{\circ} \mathrm{F}\right)$ \\
\hline EPA & U.S. Environmental Protection Agency \\
\hline ESP & Electrostatic precipitator \\
\hline FCEM & Field Chemical Emissions Monitoring \\
\hline FGD & Flue gas desulfurization \\
\hline $\mathrm{GC} / \mathrm{MS}$ & Gas chromatography/mass spectroscopy \\
\hline GFAAS & Graphite furnace atomic absorption spectrophotometry \\
\hline HGAAS & Hydride generation atomic absorption spectrophotometry \\
\hline $\mathrm{HHV}$ & Higher heating value \\
\hline IC & Ion chromatography \\
\hline ICP-AES & Inductively coupled plasma argon emissions spectrometry \\
\hline IS & Invalid sample \\
\hline LGTI & Louisiana Gasification Technology Inc. \\
\hline MS/MSD & Matrix spike/matrix spike duplicate \\
\hline
\end{tabular}


NA Not analyzed

NC Not calculated

ND Not detected

NIST

National Institute of Standards and Technology (formerly NBS)

$\mathrm{Nm}^{3} \quad$ Normal cubic meter $\left(1 \mathrm{~atm}, 0^{\circ} \mathrm{C}\right)$

$\mathrm{NO}_{x} \quad$ Nitrogen oxides

NS Not able to obtain a sample

PAH Polynuclear aromatic hydrocarbons

POM Polycyclic organic matter

QA/QC Quality assurance/quality control

RPD Relative percent difference

VOC Volatile organic compound

VOST Volatile organic sampling train

XAD Trade name for a resin used in gaseous sample collection 


\section{6}

\section{CONVERSION FACTORS}

\section{Table 6-1}

\section{Conversion Factors for SI Units}

To Convert From

To SI Unit

Multiply by

\begin{tabular}{lll}
\hline${ }^{\circ} \mathrm{F}$ & degrees Celsius $\left({ }^{\circ} \mathrm{C}\right)$ & ${ }^{\circ} \mathrm{C}=\left({ }^{\circ} \mathrm{F}-32\right) / 1.8$ \\
\hline ton, short $(2,000 \mathrm{lb})$ & kilogram $(\mathrm{kg})$ & 907.1 \\
\hline $\mathrm{atm}$ & kilopascal $(\mathrm{kPa})$ & 101.325 \\
\hline $\mathrm{gpm}$ & liter per second $(\mathrm{L} / \mathrm{s})$ & $6.309 \mathrm{E}-02$ \\
\hline Btu & joule $(\mathrm{J})$ & 1,054 \\
\hline $\mathrm{Btu} / \mathrm{lb}$ & joule per kilogram $(\mathrm{J} / \mathrm{kg})$ & 2,324 \\
\hline $\mathrm{lb}$ & kilogram $(\mathrm{kg})$ & 0.4535 \\
\hline $\mathrm{lb} / \mathrm{hr}$ & kilogram per second $(\mathrm{kg} / \mathrm{s})$ & $1.259 \mathrm{E}-04$ \\
\hline $\mathrm{psig}$ & kilopascal $(\mathrm{kPa})$ & 6.894 \\
\hline
\end{tabular}


A

\section{ANALYTICAL RESULTS}

Table A-1

CEM Data Summary

$\begin{array}{ccccc}\begin{array}{c}\text { Cxygen, } \\ \%\end{array} & \begin{array}{c}\text { Dioxide, } \\ \%\end{array} & \begin{array}{c}\text { Carbon } \\ \text { Monoxide, } \\ \text { ppmv }\end{array} & \begin{array}{c}\text { Sulfur } \\ \text { Dioxide, } \\ \text { ppmv }\end{array} & \begin{array}{c}\text { Nitrogen } \\ \text { Oxides, } \\ \text { ppmv }\end{array}\end{array}$

Turbine Stack (13)-Reporting Periods 11/3, 11/4, $11 / 7$

\begin{tabular}{llllll}
\hline Average & 15.2 & 5.9 & $<1$ & 3.1 & 70.5 \\
\hline Maximum & 16.3 & 6.1 & NC & 6.2 & 80.6 \\
\hline Minimum & 14.5 & 4.8 & NC & $<1$ & 54.6 \\
\hline Standard Deviation & 0.07 & 0.08 & NC & 1.9 & 4.9 \\
\hline Incinerator Stack (16)-Reporting Period 11/9 & 38.5 & 0.9 & 2,340 & 28 \\
\hline Average & 3.5 & 40.2 & 2.9 & 2,480 & 33.4 \\
\hline Maximum & 4.3 & 34.1 & 0 & 2,240 & 20.1 \\
\hline Minimum & 3.1 & 0.9 & 0.7 & 50 & 1.8 \\
\hline Standard Deviation & 0.3 & & & & \\
\hline
\end{tabular}


Table A-2

Turbine Stack Emissions

\begin{tabular}{|c|c|c|c|c|c|c|}
\hline \multirow[b]{2}{*}{ Analyte } & \multicolumn{2}{|c|}{ Particulate Phase } & \multicolumn{2}{|c|}{ Vapor Phase } & \multicolumn{2}{|c|}{ Total $^{a}$} \\
\hline & Average & $95 \% \mathrm{Cl}$ & Average & $95 \% \mathrm{Cl}$ & Average & $95 \% \mathrm{Cl}$ \\
\hline Particulate Loading, $\mathrm{mg} / \mathrm{Nm}^{3}$ & 3.86 & 3.5 & NS & & & \\
\hline \multicolumn{7}{|l|}{ Ionic Species, $\mu \mathrm{g} / \mathrm{Nm} 3$} \\
\hline Chloride & 68 & 200 & 350 & 270 & 420 & 110 \\
\hline Fluoride & 2.4 & 3.7 & 19 & 18 & 22 & 13 \\
\hline Sulfate & 1,100 & 680 & 23,000 & 7,500 & 24,000 & 7,500 \\
\hline Ammonia as $\mathrm{N}$ & NA & & 190 & 250 & $\mathrm{NC}$ & NC \\
\hline Cyanide & NA & & $<3.2$ & NC & NC & $\mathrm{NC}$ \\
\hline \multicolumn{7}{|l|}{ Metals, $\mu \mathrm{g} / \mathrm{Nm}^{3}$} \\
\hline Aluminum & 34 & 18 & $<15$ & $\mathrm{NC}$ & 34 & 18 \\
\hline Antimony & $<2.2$ & $\mathrm{NC}$ & $<0.022$ & $\mathrm{NC}$ & $<2.2$ & $\mathrm{NC}$ \\
\hline Arsenic & 1.1 & 1.6 & 0.084 & 0.089 & 1.2 & 1.1 \\
\hline Barium & 1.6 & 1.3 & 0.36 & 0.62 & 2 & 0.75 \\
\hline Beryllium & $<0.012$ & NC & $<0.04$ & $\mathrm{NC}$ & $<0.012$ & NC \\
\hline Boron & NA & & $<4.9$ & NC & NC & NC \\
\hline Cadmium & 0.62 & 0.035 & 0.99 & 3.1 & 1.6 & 2.2 \\
\hline Calcium & 82 & 200 & 34 & 27 & 120 & 150 \\
\hline Chromium & 1 & 0.61 & 0.47 & 0.57 & 1.5 & 0.38 \\
\hline Cobalt & 0.29 & 0.48 & 0.028 & 0.026 & 0.32 & 0.34 \\
\hline Copper & 7.5 & 15 & 0.77 & 3.2 & 8.3 & 11 \\
\hline Iron & 74 & 230 & 8 & 5.6 & 82 & 160 \\
\hline
\end{tabular}

A-2 
Table A-2

Turbine Stack Emissions

\begin{tabular}{|c|c|c|c|c|c|c|}
\hline \multirow[b]{2}{*}{ Analyte } & \multicolumn{2}{|c|}{ Particulate Phase } & \multicolumn{2}{|c|}{ Vapor Phase } & \multicolumn{2}{|c|}{ Total $^{a}$} \\
\hline & Average & $95 \% \mathrm{Cl}$ & Average & $95 \% \mathrm{Cl}$ & Average & $95 \% \mathrm{Cl}$ \\
\hline Lead & 0.99 & 1.5 & 0.6 & 0.92 & 1.6 & 0.90 \\
\hline Magnesium & 10 & 12 & $<13$ & NC & 10 & 12 \\
\hline Manganese & 0.45 & 1.3 & 1.2 & 5.2 & 1.7 & 3.8 \\
\hline Mercury & 0.01 & 0.01 & 0.7 & 0.19 & 0.71 & 0.26 \\
\hline Molybdenum & 3.8 & 3.3 & $<0.037$ & $\mathrm{NC}$ & 3.8 & 3.3 \\
\hline Nickel & 0.98 & 0.53 & 1.2 & 2.9 & 2.2 & 2.1 \\
\hline Phosphorus & 130 & 5.2 & $<31$ & $\mathrm{NC}$ & 130 & 5.2 \\
\hline Potassium & 81 & 250 & $<230$ & NC & 81 & 250 \\
\hline Selenium & 0.44 & 1.2 & 1.2 & 1.1 & 1.7 & 0.76 \\
\hline Silicon & NA & & 40 & 20 & $\mathrm{NC}$ & $\mathrm{NC}$ \\
\hline Sodium & 140 & 82 & 64 & 64 & 210 & 48 \\
\hline Titanium & 2.9 & 6.3 & 0.48 & 0.73 & 3.3 & 4.5 \\
\hline Vanadium & 0.37 & 0.19 & 0.1 & 0.21 & 0.47 & 0.13 \\
\hline Zinc & 13 & 13 & 14 & 26 & 28 & 15 \\
\hline \multicolumn{7}{|l|}{ Aldehydes, $\mu \mathrm{g} / \mathrm{Nm}^{3}$} \\
\hline Acetaldehyde & NA & & 0.99 & 0.86 & NC & NC \\
\hline Benzaldehyde & NA & & 1.7 & 1.5 & $\mathrm{NC}$ & NC \\
\hline Formaldehyde & NA & & 9.4 & 4.4 & $\mathrm{NC}$ & $\mathrm{NC}$ \\
\hline \multicolumn{7}{|c|}{ Volatile Organic Compounds, $\mu \mathrm{g} / \mathrm{Nm}^{3}$} \\
\hline 1,1,1-Trichloroethane & NS & & $<0.57$ & $\mathrm{NC}$ & $\mathrm{NC}$ & $\mathrm{NC}$ \\
\hline 1,1,2,2-Tetrachloroethane & NS & & $<0.57$ & NC & NC & $\mathrm{NC}$ \\
\hline
\end{tabular}


Table A-2

Turbine Stack Emissions

\begin{tabular}{|c|c|c|c|c|c|c|}
\hline \multirow[b]{2}{*}{ Analyte } & \multicolumn{2}{|c|}{ Particulate Phase } & \multicolumn{2}{|c|}{ Vapor Phase } & \multicolumn{2}{|c|}{ Total $^{a}$} \\
\hline & Average & $95 \% \mathrm{Cl}$ & Average & $95 \% \mathrm{Cl}$ & Average & $95 \% \mathrm{Cl}$ \\
\hline 1,1,2-Trichloroethane & NS & & $<0.57$ & $\mathrm{NC}$ & NC & $\mathrm{NC}$ \\
\hline 1,1-Dichloroethane & NS & & $<0.57$ & $\mathrm{NC}$ & $\mathrm{NC}$ & $\mathrm{NC}$ \\
\hline 1,1-Dichloroethene & NS & & $<0.57$ & $\mathrm{NC}$ & $\mathrm{NC}$ & $\mathrm{NC}$ \\
\hline 1,2-Dichlorobenzene & NS & & $<0.57$ & NC & $\mathrm{NC}$ & $\mathrm{NC}$ \\
\hline 1,2-Dichloroethane & NS & & $<0.57$ & $\mathrm{NC}$ & $\mathrm{NC}$ & $\mathrm{NC}$ \\
\hline 1,2-Dichloropropane & NS & & $<0.57$ & NC & $\mathrm{NC}$ & $\mathrm{NC}$ \\
\hline 1,3-Dichlorobenzene & NS & & $<0.57$ & $\mathrm{NC}$ & $\mathrm{NC}$ & $\mathrm{NC}$ \\
\hline 1,4-Dichlorobenzene & NS & & $<0.57$ & $\mathrm{NC}$ & $\mathrm{NC}$ & $\mathrm{NC}$ \\
\hline 2-Butanone & NS & & $<2.8$ & $\mathrm{NC}$ & $\mathrm{NC}$ & $\mathrm{NC}$ \\
\hline 2-Hexanone & NS & & $<2.8$ & $\mathrm{NC}$ & $\mathrm{NC}$ & $\mathrm{NC}$ \\
\hline 4-Methyl-2-Pentanone & NS & & $<2.8$ & $\mathrm{NC}$ & $\mathrm{NC}$ & $\mathrm{NC}$ \\
\hline Acetone & NS & & $<2.8$ & $\mathrm{NC}$ & $\mathrm{NC}$ & $\mathrm{NC}$ \\
\hline Benzene & NS & & 2.5 & 1.0 & $\mathrm{NC}$ & $\mathrm{NC}$ \\
\hline Bromodichloromethane & NS & & $<0.57$ & $\mathrm{NC}$ & $\mathrm{NC}$ & $\mathrm{NC}$ \\
\hline Bromoform & NS & & $<0.57$ & $\mathrm{NC}$ & NC & $\mathrm{NC}$ \\
\hline Bromomethane & NS & & $<0.57$ & $\mathrm{NC}$ & $\mathrm{NC}$ & NC \\
\hline Carbon Disulfide & NS & & 2.8 & 8.4 & $\mathrm{NC}$ & $\mathrm{NC}$ \\
\hline Carbon Tetrachloride & NS & & $<0.57$ & $\mathrm{NC}$ & $\mathrm{NC}$ & $\mathrm{NC}$ \\
\hline Chlorobenzene & NS & & $<0.57$ & $\mathrm{NC}$ & $\mathrm{NC}$ & $\mathrm{NC}$ \\
\hline Chloroethane & NS & & $<0.57$ & $\mathrm{NC}$ & $\mathrm{NC}$ & $\mathrm{NC}$ \\
\hline Chloroform & NS & & $<0.57$ & $\mathrm{NC}$ & $\mathrm{NC}$ & $\mathrm{NC}$ \\
\hline
\end{tabular}


Table A-2

Turbine Stack Emissions

\begin{tabular}{|c|c|c|c|c|c|c|}
\hline \multirow[b]{2}{*}{ Analyte } & \multicolumn{2}{|c|}{ Particulate Phase } & \multicolumn{2}{|c|}{ Vapor Phase } & \multicolumn{2}{|c|}{ Total $^{a}$} \\
\hline & Average & $95 \% \mathrm{Cl}$ & Average & $95 \% \mathrm{Cl}$ & Average & $95 \% \mathrm{Cl}$ \\
\hline Chloromethane & NS & & $<0.57$ & NC & NC & NC \\
\hline cis-1,3-Dichloropropene & NS & & $<0.57$ & NC & NC & NC \\
\hline Dibromochloromethane & NS & & $<0.57$ & $\mathrm{NC}$ & NC & NC \\
\hline Ethyl Benzene & NS & & $<0.57$ & NC & NC & NC \\
\hline $\mathrm{m}, \mathrm{p}$-Xylene & NS & & $<0.57$ & NC & NC & $\mathrm{NC}$ \\
\hline Methylene Chloride & NS & & 55 & 81 & NC & NC \\
\hline o-Xylene & NS & & $<0.57$ & NC & NC & NC \\
\hline Styrene & NS & & $<0.57$ & NC & NC & NC \\
\hline Tetrachloroethene & NS & & $<0.57$ & NC & NC & NC \\
\hline Toluene & NS & & $<0.57$ & $\mathrm{NC}$ & NC & NC \\
\hline trans-1,2-Dichloroethene & NS & & $<0.57$ & $\mathrm{NC}$ & NC & NC \\
\hline trans-1,3-Dichloropropene & NS & & $<0.57$ & NC & NC & NC \\
\hline Trichloroethene & NS & & $<0.57$ & NC & $\mathrm{NC}$ & NC \\
\hline Trichlorofluoromethane & NS & & 26 & 45 & NC & NC \\
\hline Vinyl Acetate & NS & & $<2.8$ & $\mathrm{NC}$ & $\mathrm{NC}$ & NC \\
\hline Vinyl Chloride & NS & & $<0.57$ & $\mathrm{NC}$ & $\mathrm{NC}$ & NC \\
\hline \multicolumn{7}{|c|}{ PAHs/SVOC Compounds, $\mu \mathrm{g} / \mathrm{Nm} 3$} \\
\hline 1,2,4-Trichlorobenzene & $<0.55$ & NC & $<0.92$ & $\mathrm{NC}$ & $\mathrm{NC}$ & NC \\
\hline 1,2-Dichlorobenzene & $<0.54$ & $\mathrm{NC}$ & $<0.96$ & NC & NC & NC \\
\hline 1,3-Dichlorobenzene & $<0.54$ & NC & $<0.92$ & NC & NC & NC \\
\hline 1,4-Dichlorobenzene & $<0.10$ & NC & $<0.90$ & $\mathrm{NC}$ & NC & NC \\
\hline
\end{tabular}


Table A-2

Turbine Stack Emissions

Particulate Phase Vapor Phase

Total $^{\mathrm{a}}$

Analyte

Average $95 \% \mathrm{Cl}$ Average $95 \% \mathrm{Cl}$ Average $95 \% \mathrm{Cl}$

\begin{tabular}{|c|c|c|c|c|c|c|}
\hline 2,2'-oxybis(1-Chloropropane) & $<0.76$ & $\mathrm{NC}$ & $<1.3$ & $\mathrm{NC}$ & $\mathrm{NC}$ & $\mathrm{NC}$ \\
\hline 2,4,5-Trichlorophenol & $<1.1$ & NC & $<1.2$ & $\mathrm{NC}$ & $\mathrm{NC}$ & $\mathrm{NC}$ \\
\hline 2,4,6-Trichlorophenol & $<1.1$ & $\mathrm{NC}$ & $<1.2$ & $\mathrm{NC}$ & $\mathrm{NC}$ & $\mathrm{NC}$ \\
\hline 2,4-Dichlorophenol & $<1.1$ & $\mathrm{NC}$ & $<1.1$ & $\mathrm{NC}$ & $\mathrm{NC}$ & $\mathrm{NC}$ \\
\hline 2,4-Dimethylphenol & $<1.1$ & $\mathrm{NC}$ & $<1.10$ & $\mathrm{NC}$ & $\mathrm{NC}$ & $\mathrm{NC}$ \\
\hline 2,4-Dinitrophenol & $<3.3$ & $\mathrm{NC}$ & $<3.2$ & $\mathrm{NC}$ & $\mathrm{NC}$ & $\mathrm{NC}$ \\
\hline 2,4-Dinitrotoluene & $<1.1$ & NC & $<1.3$ & $\mathrm{NC}$ & $\mathrm{NC}$ & $\mathrm{NC}$ \\
\hline 2,6-Dinitrotoluene & $<1.6$ & NC & $<1.8$ & NC & $\mathrm{NC}$ & $\mathrm{NC}$ \\
\hline 2-Chloronaphthalene & 0.00006 & 0.00007 & 0.00011 & 0.00007 & 0.00017 & 0.00007 \\
\hline 2-Chlorophenol & $<1.1$ & $\mathrm{NC}$ & $<1.10$ & $\mathrm{NC}$ & $\mathrm{NC}$ & $\mathrm{NC}$ \\
\hline 2-Methylnaphthalene & 0.13 & 0.32 & 0.072 & 0.024 & 0.20 & 0.32 \\
\hline 2-Methylphenol & $<1.3$ & $\mathrm{NC}$ & $<1.3$ & $\mathrm{NC}$ & $\mathrm{NC}$ & $\mathrm{NC}$ \\
\hline 2-Nitroaniline & $<1.5$ & NC & $<1.6$ & $\mathrm{NC}$ & NC & $\mathrm{NC}$ \\
\hline 2-Nitrophenol & $<1.7$ & $\mathrm{NC}$ & $<1.7$ & NC & $\mathrm{NC}$ & $\mathrm{NC}$ \\
\hline 3,3'-Dichlorobenzidine & $<1.1$ & $\mathrm{NC}$ & $<1.40$ & $\mathrm{NC}$ & $\mathrm{NC}$ & $\mathrm{NC}$ \\
\hline 3-Nitroaniline & $<1.7$ & $\mathrm{NC}$ & $<1.8$ & $\mathrm{NC}$ & $\mathrm{NC}$ & $\mathrm{NC}$ \\
\hline 3/4-Methylphenol & $<1.2$ & NC & $<1.2$ & NC & $\mathrm{NC}$ & NC \\
\hline 4,6-Dinitro-2-methylphenol & $<2.2$ & $\mathrm{NC}$ & $<2.1$ & $\mathrm{NC}$ & $\mathrm{NC}$ & $\mathrm{NC}$ \\
\hline 4-Aminobiphenyl & $<0.48$ & $\mathrm{NC}$ & $<0.51$ & $\mathrm{NC}$ & $\mathrm{NC}$ & NC \\
\hline 4-Bromophenyl-phenylether & $<1.4$ & $\mathrm{NC}$ & $<1.5$ & $\mathrm{NC}$ & $\mathrm{NC}$ & $\mathrm{NC}$ \\
\hline 4-Chloro-3-methylphenol & $<1.2$ & $\mathrm{NC}$ & $<1.1$ & $\mathrm{NC}$ & $\mathrm{NC}$ & $\mathrm{NC}$ \\
\hline
\end{tabular}


Table A-2

Turbine Stack Emissions

\begin{tabular}{|c|c|c|c|c|c|c|}
\hline \multirow[b]{2}{*}{ Analyte } & \multicolumn{2}{|c|}{ Particulate Phase } & \multicolumn{2}{|c|}{ Vapor Phase } & \multicolumn{2}{|c|}{ Total $^{a}$} \\
\hline & Average & $95 \% \mathrm{Cl}$ & Average & $95 \% \mathrm{Cl}$ & Average & $95 \% \mathrm{Cl}$ \\
\hline 4-Chloroaniline & $<0.89$ & $\mathrm{NC}$ & $<0.88$ & $\mathrm{NC}$ & $\mathrm{NC}$ & $\mathrm{NC}$ \\
\hline 4-Chlorophenyl-phenylether & $<0.80$ & NC & $<0.90$ & $\mathrm{NC}$ & NC & NC \\
\hline 4-Nitroaniline & $<1.6$ & NC & $<1.9$ & NC & NC & NC \\
\hline 4-Nitrophenol & $<1.9$ & $\mathrm{NC}$ & $<2.2$ & $\mathrm{NC}$ & NC & $\mathrm{NC}$ \\
\hline Acenaphthene & 0.0057 & 0.0078 & 0.0089 & 0.0016 & 0.015 & 0.008 \\
\hline Acenaphthylene & 0.0028 & 0.0044 & 0.006 & 0.0029 & 0.0088 & 0.0044 \\
\hline Acetophenone & $<0.88$ & NC & $<2.0$ & NC & $\mathrm{NC}$ & NC \\
\hline Aniline & $<0.74$ & NC & $<0.76$ & $\mathrm{NC}$ & NC & $\mathrm{NC}$ \\
\hline Anthracene & 0.0016 & 0.0021 & 0.0023 & 0.0012 & 0.0028 & 0.0021 \\
\hline Benzidine & $<0.64$ & $\mathrm{NC}$ & $<0.82$ & NC & $\mathrm{NC}$ & $\mathrm{NC}$ \\
\hline Benzo(a)anthracene & 0.0003 & 0.00009 & 0.001 & 0.00067 & 0.0013 & 0.0007 \\
\hline Benzo(a)pyrene & 0.0004 & 0.00003 & 0.0006 & 0.0004 & 0.001 & 0.0004 \\
\hline Benzo(b)fluoranthene & 0.0007 & 0.0001 & 0.0018 & 0.0006 & 0.0025 & 0.0006 \\
\hline Benzo(e)pyrene & 0.0013 & 0.0004 & 0.0018 & 0.0007 & 0.0031 & 0.0007 \\
\hline Benzo(g,h,i)perylene & 0.003 & 0.0004 & 0.0024 & 0.0016 & 0.0054 & 0.0016 \\
\hline Benzo(k)fluoranthene & 0.0002 & 0.0001 & 0.0004 & 0.0003 & 0.0006 & 0.0003 \\
\hline Benzoic acid ${ }^{\mathrm{b}}$ & $<2.3$ & $\mathrm{NC}$ & 80 & 38 & NC & $\mathrm{NC}$ \\
\hline Benzyl alcohol & $<1.7$ & $\mathrm{NC}$ & $<1.5$ & $\mathrm{NC}$ & $\mathrm{NC}$ & NC \\
\hline Butylbenzylphthalate & $<0.67$ & NC & $<0.80$ & $\mathrm{NC}$ & NC & NC \\
\hline Chrysene & 0.0006 & 0.0002 & 0.0019 & 0.0003 & 0.0025 & 0.0003 \\
\hline Di-n-butylphthalate ${ }^{c}$ & $<0.33$ & NC & 100 & 350 & NC & $\mathrm{NC}$ \\
\hline
\end{tabular}


Table A-2

Turbine Stack Emissions

Particulate Phase Vapor Phase $\quad$ Total $^{\mathrm{a}}$

Analyte

Average $95 \% \mathrm{Cl}$ Average $95 \% \mathrm{Cl}$ Average $95 \% \mathrm{Cl}$

\begin{tabular}{|c|c|c|c|c|c|c|}
\hline Di-n-octylphthalate & $<0.25$ & $\mathrm{NC}$ & $<0.41$ & $\mathrm{NC}$ & NC & NC \\
\hline Dibenz(a,h)anthracene & $<0.0001$ & $\mathrm{NC}$ & $<0.0002$ & NC & $\mathrm{NC}$ & NC \\
\hline Dibenzofuran & $<0.31$ & $\mathrm{NC}$ & $<0.34$ & $\mathrm{NC}$ & $\mathrm{NC}$ & NC \\
\hline Diethylphthalate & $<0.87$ & NC & $<1.4$ & NC & $\mathrm{NC}$ & NC \\
\hline Dimethylaminoazobenzene & $<0.85$ & NC & $<1.6$ & NC & NC & $\mathrm{NC}$ \\
\hline Dimethylphthalate & $<0.41$ & NC & $<0.45$ & $\mathrm{NC}$ & $\mathrm{NC}$ & NC \\
\hline Fluoranthene & 0.0053 & 0.0035 & 0.015 & 0.0047 & 0.020 & 0.005 \\
\hline Fluorene & 0.021 & 0.04 & 0.015 & 0.0036 & 0.036 & 0.04 \\
\hline Hexachlorobenzene & $<1.1$ & NC & $<1.1$ & $\mathrm{NC}$ & NC & NC \\
\hline Hexachlorobutadiene & $<1.3$ & NC & $<1.4$ & NC & NC & NC \\
\hline Hexachlorocyclopentadiene & $<1.3$ & NC & $<1.8$ & $\mathrm{NC}$ & NC & NC \\
\hline Hexachloroethane & $<1.6$ & NC & $<1.6$ & $\mathrm{NC}$ & $\mathrm{NC}$ & NC \\
\hline Indeno(1,2,3-cd)pyrene & 0.0006 & 0.00004 & 0.001 & 0.0003 & 0.0016 & 0.0003 \\
\hline Isophorone & $<0.59$ & $\mathrm{NC}$ & $<0.63$ & $\mathrm{NC}$ & NC & NC \\
\hline N-Nitroso-di-n-propylamine & $<1.7$ & NC & $<2.0$ & $\mathrm{NC}$ & $\mathrm{NC}$ & NC \\
\hline Naphthalene & 0.048 & 0.069 & 0.18 & 0.36 & NC & NC \\
\hline Nitrobenzene & $<1.0$ & NC & $<1.0$ & $\mathrm{NC}$ & NC & NC \\
\hline Pentachloronitrobenzene & $<2.8$ & NC & $<3.0$ & NC & NC & $\mathrm{NC}$ \\
\hline Pentachlorophenol & $<2.2$ & NC & $<1.8$ & NC & NC & $\mathrm{NC}$ \\
\hline Perylene & 0.0001 & 0.0001 & 0.0003 & 0.0004 & 0.0004 & 0.0004 \\
\hline Phenanthrene & 0.033 & 0.033 & 0.045 & 0.018 & 0.078 & 0.033 \\
\hline
\end{tabular}


Table A-2

Turbine Stack Emissions

\begin{tabular}{lccccccc} 
& \multicolumn{1}{c}{ Analyte } & \multicolumn{2}{c}{ Particulate Phase } & \multicolumn{2}{c}{ Vapor Phase $^{\prime}$} & \multicolumn{2}{c}{ Total $^{\mathrm{a}}$} \\
\cline { 2 - 7 } & Average & $\mathbf{9 5 \%} \mathbf{C l}$ & Average & $\mathbf{9 5 \%} \mathbf{C l}$ & Average & $\mathbf{9 5 \%} \mathbf{C l}$ \\
\hline Phenol & $<1.7$ & $\mathrm{NC}$ & $<0.74$ & $\mathrm{NC}$ & $\mathrm{NC}$ & $\mathrm{NC}$ \\
\hline Pyrene & 0.0054 & 0.0027 & 0.014 & 0.009 & $\mathrm{NC}$ & $\mathrm{NC}$ \\
\hline bis(2-Chloroethoxy)methane & $<1.1$ & $\mathrm{NC}$ & $<1.1$ & $\mathrm{NC}$ & $\mathrm{NC}$ & $\mathrm{NC}$ \\
\hline bis(2-Chloroethyl)ether & $<1.5$ & $\mathrm{NC}$ & $<1.5$ & $\mathrm{NC}$ & $\mathrm{NC}$ & $\mathrm{NC}$ \\
\hline bis(2-Ethylhexyl)phthalate & & 4.2 & 18 & $<0.65$ & $\mathrm{NC}$ & $\mathrm{NC}$ & $\mathrm{NC}$ \\
\hline n-Nitrosodimethylamine & $<3.0$ & $\mathrm{NC}$ & $<3.3$ & $\mathrm{NC}$ & $\mathrm{NC}$ & $\mathrm{NC}$ \\
\hline
\end{tabular}

'Total concentration calculated only when results for both particulate and vapor phases were analyzed.

${ }^{\mathrm{b}}$ Probable artifact of XAD resin.

${ }^{c}$ Most likely sample contamination.

NA $=$ Not analyzed.

$\mathrm{NC}=$ Not calculated .

NS $=$ Not sampled. 
Table A-3

Incinerator Stack Emissions

\section{Analyte}

Particulate Loading, $\mathrm{mg} / \mathrm{Nm}^{3}$

Particulate Phase Vapor Phase Total ${ }^{\mathrm{a}}$

Average $95 \% \mathrm{Cl}$ Average $95 \% \mathrm{Cl}$ Average $95 \% \mathrm{Cl}$

141

$26 \quad$ NA

$\mathrm{NC}$

NC

Ionic Species, $\mu \mathrm{g} / \mathrm{Nm}^{3}$

\begin{tabular}{lcccccc}
\hline Chloride & $<150$ & $\mathrm{NC}$ & $<2,100$ & $\mathrm{NC}$ & $<2,100$ & $\mathrm{NC}$ \\
\hline Fluoride & $<1.7$ & $\mathrm{NC}$ & 26 & 22 & 26 & 22 \\
\hline Sulfate $\left(\mathrm{g} / \mathrm{Nm}^{3}\right)$ & 0.14 & 0.019 & 11 & 1.7 & 12 & 1.7 \\
\hline Ammonia as N & NA & & 750 & 1,400 & NC & NC \\
\hline Cyanide & NA & 5 & 7.9 & NC & NC \\
\hline
\end{tabular}

Metals, $\mu \mathrm{g} / \mathrm{Nm}^{3}$

\begin{tabular}{lcccccc}
\hline Aluminum & 52 & 0.9 & $<18$ & $\mathrm{NC}$ & 52 & 0.9 \\
\hline Antimony & $<2.1$ & $\mathrm{NC}$ & $<0.028$ & $\mathrm{NC}$ & $<2.1$ & $\mathrm{NC}$ \\
\hline Arsenic & 0.18 & 0.41 & 0.51 & 1.2 & 0.69 & 0.90 \\
\hline Barium & 1.7 & 0.98 & 0.11 & 0.21 & 1.8 & 0.71 \\
\hline Beryllium & $<0.012$ & $\mathrm{NC}$ & $<0.051$ & $\mathrm{NC}$ & $<0.012$ & $\mathrm{NC}$ \\
\hline Boron & $\mathrm{NA}$ & & 14 & 17 & $\mathrm{NC}$ & $\mathrm{NC}$ \\
\hline Cadmium & 0.44 & 0.18 & 1.5 & 4.1 & 2 & 2.9 \\
\hline Calcium & 42 & 4.1 & 42 & 48 & 85 & 34 \\
\hline Chromium & 2.8 & 1.2 & 0.84 & 1.1 & 3.6 & 0.75 \\
\hline Cobalt & 0.33 & 0.31 & 0.048 & 0.08 & 0.38 & 0.22 \\
\hline Copper & 1.9 & 1 & 0.65 & 2.6 & 2.6 & 1.5 \\
\hline Iron & 190 & 130 & 16 & 9.8 & 200 & 89 \\
\hline
\end{tabular}

A-10 
Table A-3

Incinerator Stack Emissions

Analyte

Particulate Phase Vapor Phase $\quad$ Total $^{\mathrm{a}}$

\begin{tabular}{lcccccc}
\hline Lead & 0.27 & 0.47 & 1.9 & 2.9 & 2.2 & 2.1 \\
\hline Magnesium & 7.3 & 1.1 & $<17$ & $\mathrm{NC}$ & 7.3 & 1.1 \\
\hline Manganese & 1.4 & 0.65 & 8.2 & 30 & 9.6 & 22 \\
\hline Mercury, total & 0.015 & 0.018 & 28 & 2.4 & 28 & 3.7 \\
\hline Molybdenum & 5.1 & 0.5 & 0.048 & 0.064 & 5.2 & 0.36 \\
\hline Nickel & 3.1 & 3.1 & 2.1 & 1.4 & 5.2 & 1.8 \\
\hline Phosphorus & 180 & 12 & $<760$ & $\mathrm{NC}$ & 180 & 12 \\
\hline Potassium & $<16$ & $\mathrm{NC}$ & $<290$ & $\mathrm{NC}$ & $<16$ & $\mathrm{NC}$ \\
\hline Selenium & $<0.029$ & $\mathrm{NC}$ & $<0.21$ & $\mathrm{NC}$ & $<0.21$ & $\mathrm{NC}$ \\
\hline Silicon & $\mathrm{NA}$ & $\mathrm{NC}$ & 57 & 17 & $\mathrm{NC}$ & $\mathrm{NC}$ \\
\hline Sodium & 130 & 150 & 86 & 120 & 210 & 87 \\
\hline Titanium & 0.9 & 0.46 & $<0.55$ & $\mathrm{NC}$ & 0.9 & 0.46 \\
\hline Vanadium & 0.55 & 0.12 & 0.74 & 1.9 & 1.3 & 1.3 \\
\hline Zinc & 9.5 & 7.4 & 16 & 28 & 26 & 20 \\
\hline
\end{tabular}

Aldehydes, $\mu \mathrm{g} / \mathrm{Nm}^{3}$

\begin{tabular}{|c|c|c|c|c|c|}
\hline Acetaldehyde & NA & 0.65 & 0.95 & NC & $\mathrm{NC}$ \\
\hline Acrolein & NA & $<0.59$ & NC & $\mathrm{NC}$ & $\mathrm{NC}$ \\
\hline Benzaldehyde & NA & $<0.59$ & NC & NC & NC \\
\hline Formaldehyde & NA & 0.78 & 0.29 & $\mathrm{NC}$ & $\mathrm{NC}$ \\
\hline \multicolumn{6}{|c|}{ Volatile Organic Compounds, $\mu \mathrm{g} / \mathrm{Nm}^{3}$} \\
\hline 1,1,1-Trichloroethane & NA & $<0.55$ & NC & NC & NC \\
\hline
\end{tabular}


Table A-3

Incinerator Stack Emissions

Particulate Phase Vapor Phase

Total $^{\mathrm{a}}$

Analyte

Average $95 \% \mathrm{Cl}$ Average $95 \% \mathrm{Cl}$ Average $95 \% \mathrm{Cl}$

\begin{tabular}{|c|c|c|c|c|c|}
\hline 1,1,2,2-Tetrachloroethane & NA & $<0.55$ & NC & NC & NC \\
\hline 1,1,2-Trichloroethane & NA & $<0.55$ & $\mathrm{NC}$ & $\mathrm{NC}$ & NC \\
\hline v1,1-Dichloroethane & NA & $<0.55$ & NC & NC & NC \\
\hline 1,1-Dichloroethene & NA & $<0.55$ & NC & NC & NC \\
\hline 1,2-Dichlorobenzene & NA & $<0.55$ & $\mathrm{NC}$ & NC & NC \\
\hline 1,2-Dichloroethane & NA & $<0.55$ & $\mathrm{NC}$ & $\mathrm{NC}$ & NC \\
\hline 1,2-Dichloropropane & NA & $<0.55$ & $\mathrm{NC}$ & $\mathrm{NC}$ & NC \\
\hline 1,3-Dichlorobenzene & NA & $<0.55$ & NC & NC & NC \\
\hline 1,4-Dichlorobenzene & NA & $<0.55$ & NC & $\mathrm{NC}$ & $\mathrm{NC}$ \\
\hline 2-Butanone & NA & $<3$ & NC & $\mathrm{NC}$ & NC \\
\hline 2-Hexanone & NA & $<3$ & $\mathrm{NC}$ & NC & $\mathrm{NC}$ \\
\hline 4-Methyl-2-Pentanone & NA & $<3$ & $\mathrm{NC}$ & $\mathrm{NC}$ & NC \\
\hline Acetone & NA & $<3$ & NC & NC & NC \\
\hline Benzene & NA & 2.5 & 3 & $\mathrm{NC}$ & $\mathrm{NC}$ \\
\hline Bromodichloromethane & NA & $<0.55$ & NC & NC & NC \\
\hline Bromoform & NA & $<0.55$ & NC & NC & NC \\
\hline Bromomethane & NA & 3.8 & 2.3 & $\mathrm{NC}$ & NC \\
\hline Carbon Disulfide & NA & 5.2 & 1.6 & $\mathrm{NC}$ & $\mathrm{NC}$ \\
\hline Carbon Tetrachloride & NA & $<0.55$ & $\mathrm{NC}$ & $\mathrm{NC}$ & $\mathrm{NC}$ \\
\hline Chlorobenzene & NA & $<0.55$ & NC & $\mathrm{NC}$ & NC \\
\hline Chloroethane & NA & $<0.55$ & $\mathrm{NC}$ & NC & NC \\
\hline
\end{tabular}


Table A-3

Incinerator Stack Emissions

Analyte

Chloroform

Chloromethane

cis-1,3-Dichloropropene

Dibromochloromethane

Ethyl Benzene

m,p-Xylene

Methylene Chloride

o-Xylene

Styrene

Tetrachloroethene

Toluene

trans-1,2-Dichloroethene

trans-1,3-Dichloropropene

Trichloroethene

Trichlorofluoromethane

Vinyl Acetate

Vinyl Chloride
Particulate Phase Vapor Phase

Total $^{\mathrm{a}}$

Average $95 \% \mathrm{Cl}$ Average $95 \% \mathrm{Cl}$ Average $95 \% \mathrm{Cl}$

NA

$<0.55$

NC

NC

NC

NA

$<0.55 \quad \mathrm{NC}$

NA

$<0.55 \quad$ NC

NC

$<0.55 \quad \mathrm{NC}$

NA

NA

$<0.55$

NA

NA

NA

NA

NA

NA

NA

NA

NA

NA

NA

NA

PAHs/SVOCs, Compounds $\mu \mathrm{g} / \mathrm{Nm}^{3}$

\begin{tabular}{lllllll}
\hline 1,2,4-Trichlorobenzene & $<0.76$ & $\mathrm{NC}$ & $<0.87$ & $\mathrm{NC}$ & $\mathrm{NC}$ & $\mathrm{NC}$ \\
\hline 1,2-Dichlorobenzene & $<0.73$ & $\mathrm{NC}$ & $<0.88$ & $\mathrm{NC}$ & $\mathrm{NC}$ & $\mathrm{NC}$ \\
\hline 1,3-Dichlorobenzene & $<0.75$ & $\mathrm{NC}$ & $<0.90$ & $\mathrm{NC}$ & $\mathrm{NC}$ & $\mathrm{NC}$ \\
\hline
\end{tabular}


Table A-3

Incinerator Stack Emissions

Particulate Phase Vapor Phase

Total $^{\mathrm{a}}$

Analyte

1,4-Dichlorobenzene

2,2'-oxybis(1-Chloropropane)

2,4,5-Trichlorophenol

2,4,6-Trichlorophenol

2,4-Dichlorophenol

2,4-Dimethylphenol

2,4-Dinitrophenol

2,4-Dinitrotoluene

2,6-Dinitrotoluene

2-Chloronaphthalene

2-Chlorophenol

2-Methylnaphthalene

2-Methylphenol

2-Nitroaniline

2-Nitrophenol

3,3'-Dichlorobenzidine

3-Nitroaniline

3,4-Methylphenol

4,6-Dinitro-2-methylphenol

4-Aminobiphenyl

4-Bromophenyl-phenylether

\section{Average}

ND

$<0.98$

$<0.93$

$<0.98$

$<0.93$

$<0.96$

$<29$

$<0.99$

$<0.99$

$<1.4$

$<0.0001$

$<0.0001$

$<0.89$

0.065

0.065

$<1.1$

$<1.3$

$<1.4$

0.016

NC

$<0.95$

$N C$

$\mathrm{NC}$

$\% \mathrm{Cl}$ Average

$95 \% \mathrm{C}$

$<0.82 \quad \mathrm{NC}$

Average

$95 \% \mathrm{Cl}$ 
Table A-3

Incinerator Stack Emissions

\begin{tabular}{|c|c|c|c|c|c|c|}
\hline \multirow[b]{2}{*}{ Analyte } & \multicolumn{2}{|c|}{ Particulate Phase } & \multicolumn{2}{|c|}{ Vapor Phase } & \multicolumn{2}{|c|}{ Total $^{\mathrm{a}}$} \\
\hline & Average & $95 \% \mathrm{Cl}$ & Average & $95 \% \mathrm{Cl}$ & Average & $95 \% \mathrm{Cl}$ \\
\hline 4-Chloro-3-methylphenol & $<0.99$ & NC & $<1.1$ & $\mathrm{NC}$ & NC & NC \\
\hline 4-Chloroaniline & $<0.77$ & NC & $<0.89$ & NC & NC & NC \\
\hline 4-Chlorophenyl-phenylether & $<0.71$ & NC & $<0.84$ & NC & NC & NC \\
\hline 4-Nitroaniline & $<1.4$ & NC & $<1.7$ & NC & $\mathrm{NC}$ & NC \\
\hline 4-Nitrophenol & $<1.7$ & NC & $<2.0$ & NC & NC & NC \\
\hline Acenaphthene & 0.0097 & 0.0071 & 0.011 & 0.0048 & 0.021 & 0.0071 \\
\hline Acenaphthylene & 0.0032 & 0.002 & 0.012 & 0.0027 & 0.015 & 0.0027 \\
\hline Acetophenone & $<0.74$ & NC & $<2.0$ & $\mathrm{NC}$ & NC & NC \\
\hline Aniline & $<0.62$ & NC & $<0.74$ & NC & NC & $\mathrm{NC}$ \\
\hline Anthracene & 0.0017 & 0.0014 & 0.0014 & 0.0008 & 0.0031 & 0.0014 \\
\hline Benzidine & $<0.56$ & $\mathrm{NC}$ & $<0.69$ & NC & $\mathrm{NC}$ & $\mathrm{NC}$ \\
\hline Benzo(a)anthracene & 0.0004 & 0.0001 & 0.0009 & 0.0003 & 0.0012 & 0.0003 \\
\hline Benzo(a)pyrene & 0.0003 & 0.0002 & 0.0006 & 0.0002 & 0.0009 & 0.0002 \\
\hline Benzo(b)fluoranthene & 0.0008 & 0.0002 & 0.0019 & 0.0006 & 0.0027 & 0.0006 \\
\hline Benzo(e)pyrene & 0.0015 & 0.0008 & 0.0020 & 0.0006 & 0.0035 & 0.0008 \\
\hline Benzo(g,h,i)perylene & 0.0025 & 0.0007 & 0.0023 & 0.0012 & 0.0048 & 0.0012 \\
\hline Benzo(k)fluoranthene & 0.0008 & 0.0026 & 0.0005 & 0.0001 & 0.0013 & 0.0026 \\
\hline Benzoic acid ${ }^{\mathrm{b}}$ & $<2.0$ & NC & 81 & 20 & 81 & 20 \\
\hline Benzyl alcohol & $<1.3$ & NC & $<1.5$ & NC & NC & $\mathrm{NC}$ \\
\hline Butylbenzylphthalate & $<0.60$ & $\mathrm{NC}$ & $<0.72$ & $\mathrm{NC}$ & NC & $\mathrm{NC}$ \\
\hline Chrysene & 0.001 & 0.0007 & 0.001 & 0.003 & 0.002 & 0.002 \\
\hline
\end{tabular}


Table A-3

Incinerator Stack Emissions

Particulate Phase Vapor Phase

Total $^{a}$

\section{Analyte}

Di-n-butylphthalate ${ }^{c}$

Di-n-octylphthalate

Dibenz(a,h)anthracene

Dibenzofuran

Diethylphthalate

Dimethylaminoazobenzene

Dimethylphthalate

Fluoranthene

Fluorene

Hexachlorobenzene

Hexachlorobutadiene

Hexachlorocyclopentadiene

Hexachloroethane

Indeno(1,2,3-cd)pyrene

Isophorone

N-Nitroso-di-n-propylamine

Naphthalene

Nitrobenzene

Pentachloronitrobenzene

Pentachlorophenol

Perylene

A-16

\section{Average}

$95 \% \mathrm{Cl}$ Average

$95 \% \mathrm{Cl}$

Average

$95 \% \mathrm{Cl}$

4.1

18

31

29

35

18

$<0.35$

NC

$<0.40$

NC

NC

NC

$<0.0001$

NC

$<0.0002 \quad \mathrm{NC}$

$<0.27$

NC

$<0.32$

NC

NC

NC

$<0.32$

NC

$<1.4$

NC

$<1.1$

NC

$<1.5$

NC

$<0.42$

NC

0.014

0.0038

0.020

0.0038

$0.0061 \quad 0.0026$

$0.018 \quad 0.0085$

$0.013 \quad 0.0021$

0.031

0.0085

$<0.90$

NC

$<1.0$

NC

NC

NC

$<1$

$<1.1$

NC

$<1.3$

NC

$N C$

NC

$<1.2 \quad \mathrm{NC}$

$<1.4 \quad \mathrm{NC}$

NC

$\mathrm{NC}$

NC

$\begin{array}{llllll}<1.3 & \mathrm{NC} & <1.6 & \mathrm{NC} & \mathrm{NC} & \mathrm{NC}\end{array}$

\begin{tabular}{llllll}
0.0006 & 0.0003 & 0.0008 & 0.0003 & 0.001 & 0.0003 \\
\hline
\end{tabular}

Isophorone
N-Nitroso-di-n-propylamine
Naphthalene
Nitrobenzene
Pentachloronitrobenzene
Pentachlorophenol
Perylene
A-16

\begin{tabular}{llllll}
$<0.51$ & $\mathrm{NC}$ & $<0.60$ & $\mathrm{NC}$ & $\mathrm{NC}$ & $\mathrm{NC}$ \\
\hline$<1.4$ & $\mathrm{NC}$ & $<1.7$ & $\mathrm{NC}$ & $\mathrm{NC}$ & $\mathrm{NC}$ \\
\hline 0.088 & 0.016 & 0.094 & 0.36 & 0.18 & 0.36 \\
\hline$<0.90$ & $\mathrm{NC}$ & $<1.0$ & $\mathrm{NC}$ & $\mathrm{NC}$ & $\mathrm{NC}$ \\
\hline$<2.4$ & $\mathrm{NC}$ & $<2.8$ & $\mathrm{NC}$ & $\mathrm{NC}$ & $\mathrm{NC}$ \\
\hline$<1.9$ & $\mathrm{NC}$ & $<2.1$ & $\mathrm{NC}$ & $\mathrm{NC}$ & $\mathrm{NC}$ \\
\hline 0.0001 & 0.00006 & 0.0003 & 0.0002 & 0.0004 & 0.0002 \\
\hline
\end{tabular}


Table A-3

Incinerator Stack Emissions

\begin{tabular}{lccccccc} 
& \multicolumn{2}{c}{ Particulate Phase } & \multicolumn{2}{c}{ Vapor Phase } & \multicolumn{2}{c}{ Total $^{\mathrm{a}}$} \\
\cline { 2 - 7 } Analyte & Average & $95 \% \mathrm{Cl}$ & Average & $95 \% \mathrm{Cl}$ & Average & $95 \% \mathrm{Cl}$ \\
\hline Phenanthrene & 0.033 & 0.009 & 0.041 & 0.0048 & $\mathrm{NC}$ & $\mathrm{NC}$ \\
\hline Phenol & $<0.85$ & $\mathrm{NC}$ & $<0.74$ & $\mathrm{NC}$ & $\mathrm{NC}$ & $\mathrm{NC}$ \\
\hline Pyrene & 0.0059 & 0.0009 & 0.022 & 0.029 & 0.022 & 0.029 \\
\hline bis(2-Chloroethoxy)methane & $<0.93$ & $\mathrm{NC}$ & $<1.1$ & $\mathrm{NC}$ & $\mathrm{NC}$ & $\mathrm{NC}$ \\
\hline bis(2-Chloroethyl)ether & $<1.2$ & $\mathrm{NC}$ & $<1.5$ & $\mathrm{NC}$ & $\mathrm{NC}$ & $\mathrm{NC}$ \\
\hline bis(2-Ethylhexyl)phthalate ${ }^{\mathrm{c}}$ & $<0.06$ & $\mathrm{NC}$ & 5.3 & 23 & 5.3 & 23 \\
\hline n-Nitrosodimethylamine & $<2.5$ & $\mathrm{NC}$ & $<3.0$ & $\mathrm{NC}$ & $\mathrm{NC}$ & $\mathrm{NC}$ \\
\hline
\end{tabular}

${ }^{\text {a }}$ Total concentration calculated only when results for both particulate and vapor phases were analyzed.

${ }^{\mathrm{b}}$ Probable artifact of XAD resin.

${ }^{c}$ Likely due to sample contamination.

$\mathrm{NA}=$ Not analyzed.

$\mathrm{NC}=$ Not calculated

NS $=$ Not sampled . 
Table A-4

Synthesis Gas Streams

\begin{tabular}{|c|c|c|c|c|}
\hline \multirow[b]{2}{*}{ Analyte } & \multicolumn{2}{|c|}{ Sour Syngas (11) } & \multicolumn{2}{|c|}{ Sweet Syngas (12) } \\
\hline & Average & $95 \% \mathrm{Cl}$ & Average & $95 \% \mathrm{Cl}$ \\
\hline Particulate Loading, $\mathrm{mg} / \mathrm{Nm}^{3}$ & NS & & 0.0038 & 0.0098 \\
\hline \multicolumn{5}{|l|}{ Ionic Species, $\mu \mathrm{g} / \mathrm{Nm}^{3}$} \\
\hline Ammonia as $\mathrm{N}$ & 3,400 & 2,700 & 310 & 270 \\
\hline Chloride & $<2,100$ & $\mathrm{NC}$ & $<2,400$ & $\mathrm{NC}$ \\
\hline Cyanide & 5,600 & 12,000 & 110 & 130 \\
\hline Fluoride & 15 & 6.5 & 21 & 3.6 \\
\hline \multicolumn{5}{|c|}{ Metals, Vapor Phase (Direct AAS) } \\
\hline Arsenic & 870 & $\mathrm{NC}$ & $<220$ & $\mathrm{NC}$ \\
\hline Cadmium & $<2.2$ & $\mathrm{NC}$ & 9.5 & $\mathrm{NC}$ \\
\hline Chromium & 140 & $\mathrm{NC}$ & $<39$ & $\mathrm{NC}$ \\
\hline Lead & $<85$ & NC & $<85$ & NC \\
\hline Mercury & 6.1 & 2.1 & 3.8 & 3.6 \\
\hline Nickel & 500 & NC & 19 & NC \\
\hline Selenium & 560 & $\mathrm{NC}$ & 200 & NC \\
\hline Zinc & $<2.2$ & $\mathrm{NC}$ & $<2.2$ & NC \\
\hline \multicolumn{5}{|c|}{ Metals-Vapor Phase (Charcoal), $\mu \mathrm{g} / \mathrm{Nm}^{3}$} \\
\hline Antimony & $<1.1$ & NC & $<0.039$ & NC \\
\hline Arsenic & 270 & 270 & 6 & 2.1 \\
\hline Barium & 6.3 & 2.3 & 0.23 & 0.14 \\
\hline Beryllium & $<0.36$ & $\mathrm{NC}$ & $<0.013$ & NC \\
\hline
\end{tabular}


Table A-4

Synthesis Gas Streams

\begin{tabular}{lcccc} 
& \multicolumn{2}{c}{ Sour Syngas (11) } & \multicolumn{2}{c}{ Sweet Syngas (12) } \\
\cline { 2 - 5 } Analyte & Average & $\mathbf{9 5 \%}$ Cl & Average & $\mathbf{9 5 \%} \mathbf{C l}$ \\
\hline Cadmium & 100 & 15 & 3.2 & 0.23 \\
\hline Chromium & $<0.85$ & $\mathrm{NC}$ & $<0.031$ & $\mathrm{NC}$ \\
\hline Cobalt & 93 & 14 & 3.6 & 1.7 \\
\hline Copper & $<5.9$ & $\mathrm{NC}$ & $<0.22$ & $\mathrm{NC}$ \\
\hline Iron & 46 & 10 & 1.8 & 0.18 \\
\hline Lead & 2,300 & 190 & 85 & 12 \\
\hline Manganese & $<0.85$ & $\mathrm{NC}$ & $<0.031$ & $\mathrm{NC}$ \\
\hline Mercury & 10 & 4.2 & 0.4 & 0.57 \\
\hline Molybdenum & 11 & 13 & 0.099 & 0.024 \\
\hline Nickel & 45 & 20 & 1.6 & 0.74 \\
\hline Selenium & 17 & 24 & 0.94 & 1.5 \\
\hline Vanadium & 2.8 & 5.9 & 0.18 & 0.15 \\
\hline Zinc & 8.3 & 2.8 & 0.28 & 0.31 \\
\hline Metals, Vapor Phase (M-29) $\mu \mathbf{g} / \mathrm{Nm}^{3}$ & $<3.8$ & $\mathrm{NC}$ & 0.37 & 0.32 \\
\hline Aluminum & $<12$ & $\mathrm{NC}$ & $<12$ & $\mathrm{NC}$ \\
\hline Antimony & $<0.018$ & $\mathrm{NC}$ & $<0.017$ & $\mathrm{NC}$ \\
\hline Arsenic & 0.50 & 0.32 & 0.42 & 0.097 \\
\hline Barium & 0.064 & 0.041 & 0.17 & 0.3 \\
\hline Beryllium & $<0.033$ & $\mathrm{NC}$ & $<0.031$ & $\mathrm{NC}$ \\
\hline Boron & $<4.1$ & $\mathrm{NC}$ & 7.1 & 23 \\
\hline & & & & \\
\hline
\end{tabular}


Table A-4

Synthesis Gas Streams

Sour Syngas (11)

Sweet Syngas (12)

\begin{tabular}{|c|c|c|c|c|}
\hline \multirow[b]{2}{*}{ Analyte } & & & & \\
\hline & Average & $95 \% \mathrm{Cl}$ & Average & $95 \% \mathrm{Cl}$ \\
\hline Cadmium & 0.27 & 0.17 & 0.44 & 0.14 \\
\hline Calcium & 49 & 26 & 40 & 47 \\
\hline Chromium & 1.6 & 0.38 & 1.4 & 0.052 \\
\hline Cobalt & 0.021 & 0.02 & 0.038 & 0.043 \\
\hline Copper & $<0.046$ & NC & 3.68 & 16 \\
\hline Iron & 6.7 & 4.8 & 7.8 & 4.9 \\
\hline Lead & 0.75 & 2.1 & 0.33 & 0.48 \\
\hline Magnesium & $<11$ & NC & $<10$ & NC \\
\hline Manganese & 0.018 & 0.04 & $<0.018$ & NC \\
\hline Mercury & 0.81 & 0.93 & 0.23 & 0.22 \\
\hline Molybdenum & 0.16 & 0.032 & 0.13 & 0.046 \\
\hline Nickel & 2.3 & 3.7 & 1.2 & 0.3 \\
\hline Phosphorus & $<25$ & NC & $<24$ & NC \\
\hline Potassium & $<190$ & NC & $<180$ & NC \\
\hline Selenium & 0.18 & 0.5 & 0.26 & 0.84 \\
\hline Silicon & 26 & 18 & 33 & 17 \\
\hline Sodium & 27 & 9.6 & 40 & 60 \\
\hline Titanium & $<0.37$ & $\mathrm{NC}$ & $<0.330$ & NC \\
\hline Vanadium & 0.060 & 0.011 & 0.050 & 0.017 \\
\hline Zinc & 8.7 & 2.7 & 5.3 & 2.1 \\
\hline
\end{tabular}


Table A-4

Synthesis Gas Streams

\begin{tabular}{|c|c|c|c|c|}
\hline \multirow[b]{2}{*}{ Analyte } & \multicolumn{2}{|c|}{ Sour Syngas (11) } & \multicolumn{2}{|c|}{ Sweet Syngas (12) } \\
\hline & Average & $95 \% \mathrm{Cl}$ & Average & $95 \% \mathrm{Cl}$ \\
\hline \multicolumn{5}{|l|}{ Aldehydes, $\mu \mathrm{g} / \mathrm{Nm}^{3}$} \\
\hline Acetaldehyde & 9.2 & 0.99 & 140 & 41 \\
\hline Acrolein & $<0.6$ & $\mathrm{NC}$ & $<1.3$ & $\mathrm{NC}$ \\
\hline Benzaldehyde & 0.72 & 1.1 & $<1.3$ & $\mathrm{NC}$ \\
\hline Formaldehyde & 1.6 & 1.6 & 2.3 & 2.3 \\
\hline \multicolumn{5}{|c|}{ PAHs/SVOCs-Vapor Phase, $\mu \mathrm{g} / \mathrm{Nm}^{3}$} \\
\hline 1,2,4-Trichlorobenzene & $<1.8$ & $\mathrm{NC}$ & $<1.5$ & $\mathrm{NC}$ \\
\hline 1,2-Dichlorobenzene & $<2.4$ & NC & $<2.1$ & $\mathrm{NC}$ \\
\hline 1,3-Dichlorobenzene & $<2.2$ & $\mathrm{NC}$ & $<2.0$ & $\mathrm{NC}$ \\
\hline 1,4-Dichlorobenzene & $<3.8$ & $\mathrm{NC}$ & $<3.4$ & NC \\
\hline 2,4,5-Trichlorophenol & $<3.2$ & NC & $<2.8$ & NC \\
\hline 2,4,6-Trichlorophenol & $<3.0$ & $\mathrm{NC}$ & $<2.6$ & NC \\
\hline 2,4-Dimethylphenol & $<2.6$ & $\mathrm{NC}$ & $<8.7$ & $\mathrm{NC}$ \\
\hline 2,4-Dinitrophenol & $<10$ & NC & $<18$ & $\mathrm{NC}$ \\
\hline 2,4-Dinitrotoluene & $<21$ & $\mathrm{NC}$ & $<3.2$ & $\mathrm{NC}$ \\
\hline 2,6-Dinitrotoluene & $<3.6$ & $\mathrm{NC}$ & $<2.7$ & $\mathrm{NC}$ \\
\hline 2-Chloronaphthalene & $<3.0$ & $\mathrm{NC}$ & $<4.3$ & $\mathrm{NC}$ \\
\hline 2-Chlorophenol & $<4.9$ & $\mathrm{NC}$ & $<3.1$ & $\mathrm{NC}$ \\
\hline 2-Fluorophenol & $<3.5$ & $\mathrm{NC}$ & 49 & 9.4 \\
\hline 2-Methylnaphthalene & 60 & 21 & 8.9 & 3 \\
\hline 2-Methylphenol & $<9.0$ & $\mathrm{NC}$ & $<7.9$ & $\mathrm{NC}$ \\
\hline
\end{tabular}


Table A-4

Synthesis Gas Streams

Sour Syngas (11)

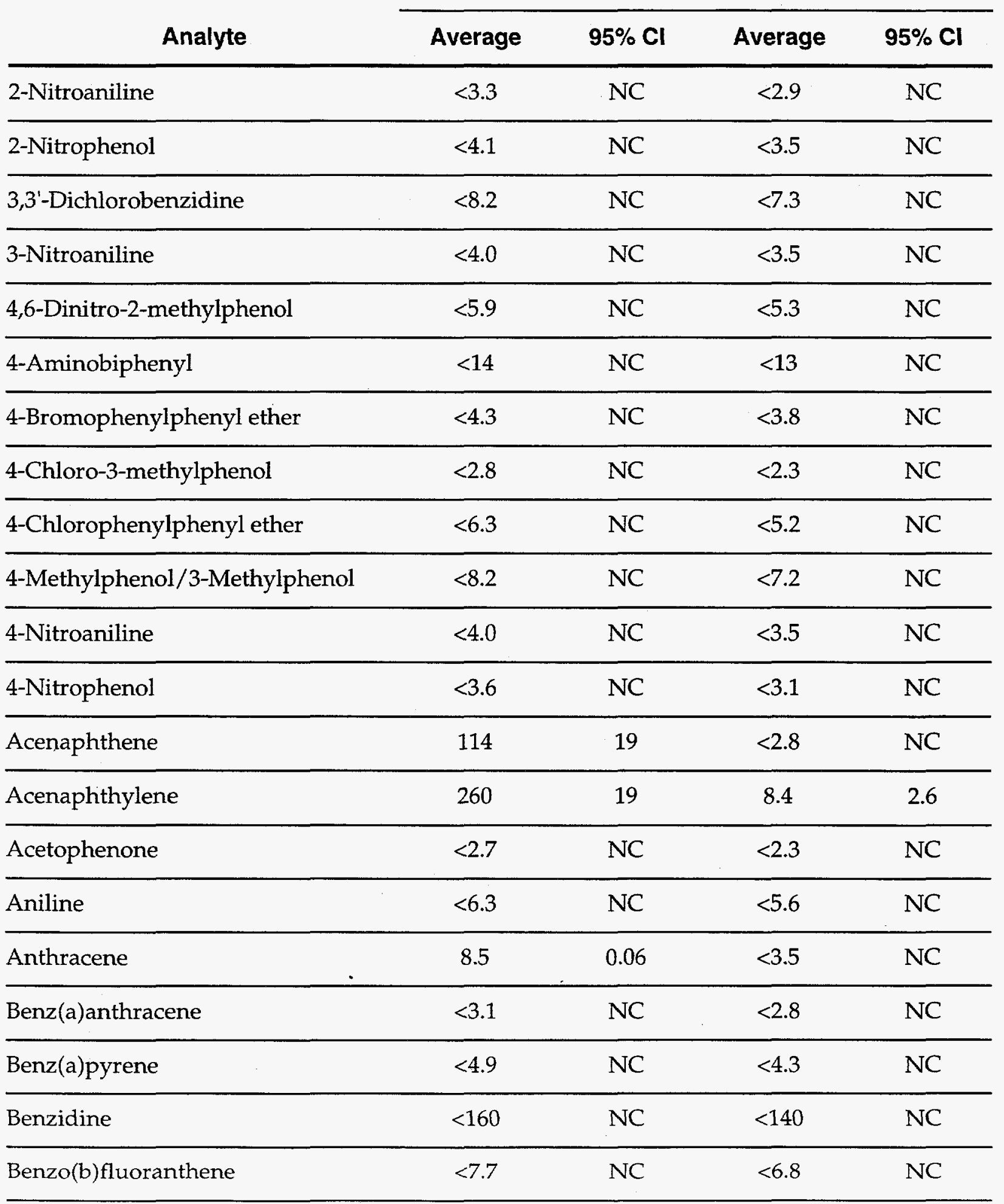

\section{Analyte}


Table A-4

Synthesis Gas Streams

\begin{tabular}{|c|c|c|c|c|}
\hline \multirow[b]{2}{*}{ Analyte } & \multicolumn{2}{|c|}{ Sour Syngas (11) } & \multicolumn{2}{|c|}{ Sweet Syngas (12) } \\
\hline & Average & $95 \% \mathrm{Cl}$ & Average & $95 \% \mathrm{Cl}$ \\
\hline Benzo(g,h,i)perylene & $<3.4$ & $\mathrm{NC}$ & $<3.0$ & NC \\
\hline Benzo(k)fluoranthene & $<5.2$ & NC & $<4.6$ & NC \\
\hline Benzoic acid & $<50$ & NC & $<42$ & NC \\
\hline Benzyl alcohol & $<3.6$ & NC & $<3.2$ & $\mathrm{NC}$ \\
\hline Butylbenzylphthalate & $<4.1$ & NC & $<3.7$ & NC \\
\hline Chrysene & $<2.1$ & NC & $<1.9$ & NC \\
\hline Di-n-butylphthalate & $<3.4$ & NC & $<3.0$ & NC \\
\hline Di-n-octylphthalate & $<3.5$ & $\mathrm{NC}$ & $<3.1$ & NC \\
\hline Dibenz(a,h)anthracene & $<3.8$ & NC & $<3.4$ & NC \\
\hline Dibenzofuran & 22 & 7 & $<2.5$ & NC \\
\hline Diethylphthalate & $<26$ & NC & $<2.2$ & NC \\
\hline Dimethylphthalate & $<27$ & NC & $<2.2$ & NC \\
\hline Diphenylamine/N-NitrosoDPA & $<61$ & NC & $<5.1$ & NC \\
\hline Fluoranthene & 8 & NC & $<1.2$ & NC \\
\hline Fluorene & 28 & 97 & $<2.0$ & $\mathrm{NC}$ \\
\hline Hexachlorobenzene & $<3.7$ & NC & $<3.3$ & NC \\
\hline Hexachlorobutadiene & $<2$ & NC & $<1.7$ & NC \\
\hline Hexachlorocyclopentadiene & $<13$ & NC & $<11$ & NC \\
\hline Hexachloroethane & $<1.9$ & NC & $<1.7$ & NC \\
\hline Indeno(1,2,3-cd)pyrene & $<4.1$ & NC & $<3.6$ & NC \\
\hline Isophorone & $<3.1$ & NC & $<2.6$ & NC \\
\hline
\end{tabular}


Table A-4

Synthesis Gas Streams

\begin{tabular}{|c|c|c|c|c|}
\hline \multirow[b]{2}{*}{ Analyte } & \multicolumn{2}{|c|}{ Sour Syngas (11) } & \multicolumn{2}{|c|}{ Sweet Syngas (12) } \\
\hline & Average & $95 \% \mathrm{Cl}$ & Average & $95 \% \mathrm{Cl}$ \\
\hline N-Nitroso-di-n-propylamine & $<4.5$ & NC & $<3.9$ & NC \\
\hline N-Nitrosodimethylamine & $<3.3$ & NC & $<2.9$ & NC \\
\hline Naphthalene & 6,900 & 1,300 & 960 & 88 \\
\hline Nitrobenzene & $<2.7$ & NC & $<2.2$ & NC \\
\hline Pentachloronitrobenzene & $<8.7$ & NC & $<7.7$ & NC \\
\hline Pentachlorophenol & 17 & 58 & $<1.3$ & NC \\
\hline Phenanthrene & 55 & 87 & $<2.5$ & NC \\
\hline Phenol & 7.6 & 35 & $<3.7$ & NC \\
\hline Pyrene & 10 & 9.6 & $<1.7$ & NC \\
\hline bis(2-Chloroethoxy)methane & $<2.3$ & NC & $<1.9$ & NC \\
\hline bis(2-Chloroethyl)ether & $<3.1$ & NC & $<2.7$ & NC \\
\hline bis(2-Chloroisopropyl)ether & $<3.4$ & NC & $<3.0$ & NC \\
\hline bis(2-Ethylhexyl)phthalate & $<14$ & NC & $<12$ & NC \\
\hline p-Chloroaniline & $<4.9$ & NC & $<4.1$ & NC \\
\hline p-Dimethylaminoazobenzene & $<18$ & NC & $<16$ & NC \\
\hline \multicolumn{5}{|l|}{ Gas Composition } \\
\hline Hydrogen (mol \%) & 32 & 4 & 32 & 8 \\
\hline Nitrogen (mol \%) & 2 & 2 & 2 & 0.5 \\
\hline Oxygen/Argon (mol \%) & $<1$ & NC & $<1$ & NC \\
\hline Carbon Dioxide (mol \%) & 31 & 2 & 30 & 5 \\
\hline Carbon Monoxide ( $\mathrm{mol} \%$ ) & 33 & 2 & 33 & 3 \\
\hline
\end{tabular}


Table A-4

Synthesis Gas Streams

\begin{tabular}{lcccc} 
& \multicolumn{2}{c}{ Sour Syngas (11) } & \multicolumn{2}{c}{ Sweet Syngas (12) } \\
\cline { 2 - 5 } & Average & $95 \% \mathbf{C l}$ & Average & $95 \% \mathbf{C l}$ \\
\hline Methane (mol \%) & 2 & 0.1 & 2 & 0.1 \\
\hline $\mathrm{C}$ (ppmv) & 7.8 & 0.1 & 9.2 & 1.2 \\
\hline $\mathrm{C} 3$ (ppmv) & 0.2 & 0.3 & 0.2 & 0.2 \\
\hline $\mathrm{C} 4$ (ppmv) & $<0.1$ & $\mathrm{NC}$ & $<0.1$ & $\mathrm{NC}$ \\
\hline $\mathrm{C} 5$ (ppmv) & 0.1 & 0.1 & 0.1 & 0.1 \\
\hline $\mathrm{C} 6$ (ppmv) & 250 & 16 & 240 & 23 \\
\hline $\mathrm{C} 7$ (ppmv) & 1 & 0.5 & 2.9 & 3.1 \\
\hline $\mathrm{C} 8$ (ppmv) & $<0.1$ & $\mathrm{NC}$ & $<0.1$ & $\mathrm{NC}$ \\
\hline $\mathrm{H}_{2} \mathrm{~S}$ (ppmv) & 920 & 70 & 27 & 10 \\
\hline $\mathrm{COS}$ (ppmv) & 29 & 4 & 26 & 2 \\
\hline $\mathrm{CS}$ (ppmv) & $<1$ & $\mathrm{NC}$ & $<1$ & $\mathrm{NC}$ \\
\hline
\end{tabular}

$\mathrm{NC}=$ Not calculated . 
Table A-5

Internal Process Streams

\begin{tabular}{lcccccc} 
& \multicolumn{2}{c}{ Sour Gas (22) } & \multicolumn{2}{c}{ Acid Gas (14) } & \multicolumn{2}{c}{ Tail Gas (15) } \\
\cline { 2 - 7 } Analyte & Average & $\mathbf{9 5 \%} \mathbf{C l}$ & Average & $\mathbf{9 5 \%} \mathbf{C l}$ & Average & $\mathbf{9 5 \%} \mathbf{~ C l}$ \\
\hline $\mathbf{n}, \mathbf{m g} / \mathrm{Nm}^{3}$ & & & & & & \\
\hline $\mathrm{N}$ & $34 \%$ & $11 \%$ & 19 & 12 & 100 & 130 \\
\hline & $\mathrm{NS}$ & & $<5.6$ & $\mathrm{NC}$ & $\mathrm{NC}$ & $\mathrm{NC}$ \\
\hline & 190 & 110 & 1.4 & 0.15 & 89 & 22 \\
\hline $\mathrm{NS}$ & & 0.042 & 0.018 & $\mathrm{NC}$ & $\mathrm{NC}$ \\
\hline
\end{tabular}

\begin{tabular}{lllll}
\hline Metals-Vapor Phase (Charcoal), $\mu \mathbf{g} / \mathbf{N m}^{3}$ & & & & \\
\hline Antimony & NS & $<.1$ & NC & NS \\
\hline Arsenic & NS & 4.9 & 7.3 & NS \\
\hline Barium & NS & 12 & 5.4 & NS \\
\hline Beryllium & NS & $<0.69$ & NC & NS \\
\hline Boron & NS & 180 & 56 & NS \\
\hline Cadmium & NS & $<1.6$ & NC & NS \\
\hline Chromium & NS & 210 & 78 & NS \\
\hline Cobalt & NS & $<11$ & NC & NS \\
\hline Copper & NS & 58 & 20 & NS \\
\hline Iron & NS & 4,000 & 1,600 & NS \\
\hline Lead & NS & 9.6 & 30 & NS \\
\hline Manganese & NS & 11 & 27 & NS \\
\hline Mercury & NS & 4 & 1.1 & NS \\
\hline Molybdenum & NS & 72 & 13 & NS \\
\hline
\end{tabular}

A-26 
Table A-5

Internal Process Streams

\begin{tabular}{|c|c|c|c|c|c|c|}
\hline \multirow[b]{2}{*}{ Analyte } & \multicolumn{2}{|c|}{ Sour Gas (22) } & \multicolumn{2}{|c|}{ Acid Gas (14) } & \multicolumn{2}{|c|}{ Tail Gas (15) } \\
\hline & Average & $95 \% \mathrm{Cl}$ & Average & $95 \% \mathrm{Cl}$ & Average & $95 \% \mathrm{Cl}$ \\
\hline Nickel & NS & & 25 & 29 & NS & \\
\hline Selenium & NS & & $<1.7$ & NC & NS & \\
\hline Vanadium & NS & & 9.9 & 8.2 & NS & \\
\hline Zinc & NS & & $<7.3$ & NC & NS & \\
\hline \multicolumn{7}{|c|}{ Metals-Vapor Phase (M-29), $\mu \mathrm{g} / \mathrm{Nm}^{3}$} \\
\hline Aluminum & NS & & $<13$ & NC & $<120$ & NC \\
\hline Antimony & NS & & 0.062 & 0.043 & $<0.18$ & NC \\
\hline Arsenic & NS & & 2.7 & 4.9 & 0.4 & 1.2 \\
\hline Barium & NS & & 0.47 & 0.5 & 0.69 & 1.9 \\
\hline Beryllium & NS & & $<0.034$ & NC & $<0.32$ & NC \\
\hline Boron & NS & & 5.8 & 9 & $<40$ & NC \\
\hline Cadmium & NS & & 0.41 & 0.26 & 1.7 & 5.6 \\
\hline Calcium & NS & & 95 & 110 & 220 & 580 \\
\hline Chromium & NS & & 65 & 110 & 27 & 110 \\
\hline Cobalt & NS & & 1.2 & 1.8 & 6.5 & 25 \\
\hline Copper & NS & & 15 & 21 & 3.8 & 9 \\
\hline Iron & NS & & 140 & 190 & 34 & 91 \\
\hline Lead & NS & & 0.66 & 0.71 & 7.8 & 25 \\
\hline Magnesium & NS & & 21 & 30 & $<110$ & $\mathrm{NC}$ \\
\hline Manganese & NS & & 19 & 45 & 0.76 & 1.9 \\
\hline Mercury & NS & & 0.99 & 1.2 & 11 & 31 \\
\hline
\end{tabular}


Table A-5

Internal Process Streams

Sour Gas (22) Acid Gas (14) Tail Gas (15)

Analyte

Average $95 \% \mathrm{Cl}$ Average $95 \% \mathrm{Cl}$ Average $95 \% \mathrm{Cl}$

\begin{tabular}{|c|c|c|c|c|c|}
\hline Molybdenum & NS & 4.6 & 7.2 & 0.61 & 1.7 \\
\hline Nickel & NS & 230 & 340 & 33 & 60 \\
\hline Phosphorus & NS & 88 & 120 & $<5,000$ & $\mathrm{NC}$ \\
\hline Potassium & NS & $<200$ & $\mathrm{NC}$ & $<1,900$ & NC \\
\hline Selenium & NS & 3.7 & 9.7 & $<1.3$ & NC \\
\hline Silicon & NS & 74 & 36 & 170 & 480 \\
\hline Sodium & NS & 78 & 110 & 270 & 740 \\
\hline Titanium & NS & 0.82 & 0.91 & $<3.6$ & $\mathrm{NC}$ \\
\hline Vanadium & NS & 0.94 & 2.5 & 0.42 & 1.2 \\
\hline Zinc & NS & 14 & 34 & 50 & 120 \\
\hline \multicolumn{6}{|c|}{ PAHs/SVOCs-Vapor Phase, $\mu \mathrm{g} / \mathrm{Nm}^{3}$} \\
\hline 1,2,4-Trichlorobenzene & NS & NA & $\mathrm{NC}$ & $<60$ & NC \\
\hline 1,2-Dichlorobenzene & NS & $<4.5$ & $\mathrm{NC}$ & $<11$ & NC \\
\hline 1,3-Dichlorobenzene & NS & $<4.2$ & $\mathrm{NC}$ & $<10$ & NC \\
\hline 1,4-Dichlorobenzene & NS & $<7.2$ & $\mathrm{NC}$ & $<17$ & $\mathrm{NC}$ \\
\hline 2,4,5-Trichlorophenol & NS & $<6.0$ & $\mathrm{NC}$ & $<15$ & NC \\
\hline $2,4,6$-Tribromophenol & NS & 23 & 6.2 & NA & \\
\hline 2,4,6-Trichlorophenol & NS & $<5.6$ & $\mathrm{NC}$ & $<13$ & NC \\
\hline 2,4-Dichlorophenol & NS & NA & $\mathrm{NC}$ & $<180$ & $\mathrm{NC}$ \\
\hline 2,4-Dimethylphenol & NS & NA & $\mathrm{NC}$ & $<400$ & $\mathrm{NC}$ \\
\hline 2,4-Dinitrophenol & NS & $<39$ & $\mathrm{NC}$ & $<95$ & NC \\
\hline
\end{tabular}


Table A-5

Internal Process Streams

\begin{tabular}{|c|c|c|c|c|c|c|}
\hline \multirow[b]{2}{*}{ Analyte } & \multicolumn{2}{|c|}{ Sour Gas (22) } & \multicolumn{2}{|c|}{ Acid Gas (14) } & \multicolumn{2}{|c|}{ Tail Gas (15) } \\
\hline & Average & $95 \% \mathrm{Cl}$ & Average & $95 \% \mathrm{Cl}$ & Average & $95 \% \mathrm{CI}$ \\
\hline 2,4-Dinitrotoluene & NS & & $<6.7$ & $\mathrm{NC}$ & $<16$ & $\mathrm{NC}$ \\
\hline 2,6-Dinitrotoluene & NS & & $<5.7$ & $\mathrm{NC}$ & $<14$ & $\mathrm{NC}$ \\
\hline 2-Chloronaphthalene & NS & & $<9.2$ & $\mathrm{NC}$ & $<22$ & $\mathrm{NC}$ \\
\hline 2-Chlorophenol & NS & & $<6.7$ & $\mathrm{NC}$ & $<16$ & $\mathrm{NC}$ \\
\hline 2-Fluorobiphenyl & NS & & 17 & 2.3 & NA & \\
\hline 2-Fluorophenol & NS & & 25.7 & 4.4 & NA & \\
\hline 2-Methylnaphthalene & NS & & $<640$ & $\mathrm{NC}$ & $<520$ & $\mathrm{NC}$ \\
\hline 2-Methylphenol & NS & & $<17$ & $\mathrm{NC}$ & $<41$ & NC \\
\hline 2-Nitroaniline & NS & & $<6.2$ & $\mathrm{NC}$ & $<15$ & NC \\
\hline 2-Nitrophenol & NS & & NA & $\mathrm{NC}$ & $<130$ & NC \\
\hline 3,3'-Dichlorobenzidine & NS & & $<15$ & $\mathrm{NC}$ & $<37$ & NC \\
\hline 3-Nitroaniline & NS & & $<7.5$ & $\mathrm{NC}$ & $<18$ & $\mathrm{NC}$ \\
\hline 4,6-Dinitro-2-methylphenol & NS & & $<11$ & $\mathrm{NC}$ & $<27$ & NC \\
\hline 4-Aminobiphenyl & NS & & $<27$ & $\mathrm{NC}$ & $<64$ & $\mathrm{NC}$ \\
\hline 4-Bromophenylphenyl ether & NS & & $<8.0$ & $\mathrm{NC}$ & $<19$ & $\mathrm{NC}$ \\
\hline 4-Chloro-3-methylphenol & NS & & NA & NC & $<140$ & $\mathrm{NC}$ \\
\hline 4-Chlorophenylphenyl ether & NS & & $<11$ & $\mathrm{NC}$ & $<27$ & NC \\
\hline 4-Methylphenol/3-Methylphenol & NS & & $<15$ & NC & $<37$ & $\mathrm{NC}$ \\
\hline 4-Nitroaniline & NS & & $<7.5$ & $\mathrm{NC}$ & $<18$ & $\mathrm{NC}$ \\
\hline 4-Nitrophenol & NS & & $<6.7$ & $\mathrm{NC}$ & $<16$ & $\mathrm{NC}$ \\
\hline Acenaphthene & NS & & 1,700 & 440 & 44 & 140 \\
\hline
\end{tabular}


Table A-5

Internal Process Streams

Sour Gas (22)

Acid Gas (14)

Tail Gas (15)

Analyte

Average $95 \% \mathrm{Cl}$ Average $95 \% \mathrm{Cl}$ Average $95 \% \mathrm{Cl}$

\begin{tabular}{|c|c|c|c|c|c|}
\hline Acenaphthylene & NS & 3,100 & 800 & $<27$ & $\mathrm{NC}$ \\
\hline Acetophenone & NS & $<5.0$ & NC & $<12$ & $\mathrm{NC}$ \\
\hline Aniline & NS & $<12$ & $\mathrm{NC}$ & $<29$ & $\mathrm{NC}$ \\
\hline Anthracene & NS & 31 & 18 & $<18$ & $\mathrm{NC}$ \\
\hline Benz(a)anthracene & NS & $<5.9$ & NC & $<14$ & $\mathrm{NC}$ \\
\hline Benz(a)pyrene & NS & $<9.2$ & NC & $<22$ & NC \\
\hline Benzidine & NS & $<290$ & $\mathrm{NC}$ & $<710$ & $\mathrm{NC}$ \\
\hline Benzo(b)fluoranthene & NS & $<14$ & NC & $<35$ & $\mathrm{NC}$ \\
\hline Benzo(g,h,I)perylene & NS & $<6.4$ & $\mathrm{NC}$ & $<15$ & NC \\
\hline Benzo(k)fluoranthene & NS & $<9.7$ & $\mathrm{NC}$ & $<23$ & NC \\
\hline Benzoic acid & NS & NA & & $<940$ & NC \\
\hline Benzyl alcohol & NS & $<6.8$ & $\mathrm{NC}$ & $<16$ & NC \\
\hline Butylbenzylphthalate & NS & $<7.8$ & NC & $<19$ & $\mathrm{NC}$ \\
\hline Chrysene & NS & $<4.1$ & $\mathrm{NC}$ & $<9.7$ & $\mathrm{NC}$ \\
\hline Di-n-butylphthalate & NS & $<6.5$ & $\mathrm{NC}$ & $<16$ & NC \\
\hline Di-n-octylphthalate & NS & $<6.5$ & NC & $<16$ & NC \\
\hline Dibenz(a,h)anthracene & NS & $<7.2$ & $\mathrm{NC}$ & $<17$ & NC \\
\hline Dibenzofuran & NS & 270 & 82 & 160 & 440 \\
\hline Diethylphthalate & NS & $<4.6$ & $\mathrm{NC}$ & $<11$ & $\mathrm{NC}$ \\
\hline Dimethylphthalate & NS & $<4.8$ & $\mathrm{NC}$ & $<11$ & $\mathrm{NC}$ \\
\hline Diphenylamine/N-NitrosoDPA & NS & $<11$ & NC & $<26$ & NC \\
\hline
\end{tabular}


Table A-5

Internal Process Streams

\begin{tabular}{|c|c|c|c|c|c|c|}
\hline \multirow[b]{2}{*}{ Analyte } & \multicolumn{2}{|c|}{ Sour Gas (22) } & \multicolumn{2}{|c|}{ Acid Gas (14) } & \multicolumn{2}{|c|}{ Tail Gas (15) } \\
\hline & Average & $95 \% \mathrm{Cl}$ & Average & $95 \% \mathrm{Cl}$ & Average & $95 \% \mathrm{Cl}$ \\
\hline Fluoranthene & NS & & $<2.5$ & $\mathrm{NC}$ & $<6.0$ & NC \\
\hline Fluorene & NS & & 660 & 12 & 11 & 81 \\
\hline Hexachlorobenzene & NS & & $<7.0$ & $\mathrm{NC}$ & $<17$ & $\mathrm{NC}$ \\
\hline Hexachlorobutadiene & NS & & NA & & $<210$ & $\mathrm{NC}$ \\
\hline Hexachlorocyclopentadiene & NS & & $<24$ & NC & $<58$ & $\mathrm{NC}$ \\
\hline Hexachloroethane & NS & & $<3.6$ & NC & $<8.7$ & $\mathrm{NC}$ \\
\hline Indeno(1,2,3-cd)pyrene & NS & & $<7.7$ & $\mathrm{NC}$ & $<18$ & $\mathrm{NC}$ \\
\hline Isophorone & NS & & NA & & $<95$ & NC \\
\hline N-Nitroso-di-n-propylamine & NS & & $<8.4$ & $\mathrm{NC}$ & $<20$ & $\mathrm{NC}$ \\
\hline N-Nitrosodimethylamine & NS & & $<6.2$ & $\mathrm{NC}$ & $<15$ & $\mathrm{NC}$ \\
\hline Naphthalene & NS & & 110,000 & 28,000 & 89,000 & 38,000 \\
\hline Nitrobenzene & NS & & NA & & $<120$ & NC \\
\hline Pentachloronitrobenzene & NS & & $<16$ & NC & $<39$ & $\mathrm{NC}$ \\
\hline Pentachlorophenol & NS & & $<2.7$ & NC & $<6.4$ & $\mathrm{NC}$ \\
\hline Phenanthrene & NS & & 240 & 290 & $<150$ & $\mathrm{NC}$ \\
\hline Phenol & NS & & $<7.9$ & $\mathrm{NC}$ & $<19$ & $\mathrm{NC}$ \\
\hline Pyrene & NS & & $<3.6$ & NC & $<8.6$ & NC \\
\hline bis(2-Chloroethoxy)methane & NS & & NA & & $<110$ & $\mathrm{NC}$ \\
\hline bis(2-Chloroethyl)ether & NS & & $<5.9$ & $\mathrm{NC}$ & $<14$ & NC \\
\hline bis(2-Chloroisopropyl)ether & NS & & $<6.4$ & NC & $<15$ & NC \\
\hline bis(2-Ethylhexyl)phthalate & NS & & $<26$ & $\mathrm{NC}$ & $<63$ & $\mathrm{NC}$ \\
\hline
\end{tabular}


Table A-5

Internal Process Streams

Sour Gas (22) Acid Gas (14) Tail Gas (15)

Analyte

Average $95 \% \mathrm{Cl}$ Average $95 \% \mathrm{Cl}$ Average $95 \% \mathrm{Cl}$

\begin{tabular}{|c|c|c|c|c|c|c|}
\hline $\mathrm{p}$-Chloroaniline & NS & & NA & & $<310$ & $\mathrm{NC}$ \\
\hline p-Dimethylaminoazobenzene & NS & & $<33$ & NC & $<80$ & NC \\
\hline \multicolumn{7}{|l|}{ Gas Composition } \\
\hline Hydrogen (mol \%) & NA & & $<1$ & $\mathrm{NC}$ & NA & \\
\hline Nitrogen (mol \%) & NA & & $<1$ & NC & 3 & 0.3 \\
\hline Oxygen/Argon (mol \%) & NA & & $<1$ & $\mathrm{NC}$ & $<1$ & NC \\
\hline Carbon Dioxide (mol \%) & NA & & 98 & $\mathrm{NC}$ & 97 & 0.3 \\
\hline Carbon Monoxide ( $\mathrm{mol} \%$ ) & NA & & $<1$ & $\mathrm{NC}$ & $<0.1$ & $N C$ \\
\hline Methane (ppmv) & 700 & 50 & 420 & 44 & 390 & 40 \\
\hline C2 (ppmv) & 5.4 & 0.5 & 2.3 & 0.6 & 1.3 & 0.5 \\
\hline C3 (ppmv) & 170 & 40 & 8.8 & 2.4 & 6.5 & 4.7 \\
\hline C4 (ppmv) & 7 & 4 & $<0.1$ & $\mathrm{NC}$ & $<0.1$ & $\mathrm{NC}$ \\
\hline C5 (ppmv) & $<0.1$ & $\mathrm{NC}$ & $<0.1$ & $\mathrm{NC}$ & $<0.1$ & $\mathrm{NC}$ \\
\hline C6 (ppmv) & 440 & 20 & 350 & 24 & 330 & 30 \\
\hline C7 (ppmv) & 2 & 3 & 2.1 & 1.5 & 2.7 & 2 \\
\hline C8 (ppmv) & 6 & 7 & $<0.1$ & $\mathrm{NC}$ & 2 & 4 \\
\hline $\mathrm{H}_{2} \mathrm{~S}$ (ppmv) & $1.3 \%$ & $\mathrm{NC}$ & $1.5 \%$ & 0.2 & 3,000 & 300 \\
\hline $\operatorname{COS}(\mathrm{ppmv})$ & $<1$ & $\mathrm{NC}$ & 170 & $\mathrm{NC}$ & 85 & 55 \\
\hline $\mathrm{CS}_{2}(\mathrm{ppmv})$ & $<1$ & $\mathrm{NC}$ & $<1$ & NC & 42 & 28 \\
\hline
\end{tabular}


Table A-6

Incinerator Fuel Gases

\begin{tabular}{|c|c|c|c|c|}
\hline \multirow[b]{2}{*}{ Analyte } & \multicolumn{2}{|c|}{ Natural Gas (99) } & \multicolumn{2}{|c|}{ Combustion Air (97) } \\
\hline & Average & $95 \% \mathrm{Cl}$ & Average & $95 \% \mathrm{Cl}$ \\
\hline \multicolumn{5}{|c|}{ Ionic Species, $\mathrm{mg} / \mathrm{Nm}^{3}$} \\
\hline Ammonia as $\mathrm{N}$ & NA & & 460 & 55 \\
\hline Cyanide & NA & & 10 & 2.4 \\
\hline \multicolumn{5}{|c|}{ Metals-Vapor Phase (M-29), $\mu \mathrm{g} / \mathrm{Nm}^{3}$} \\
\hline Aluminum & $<12$ & $\mathrm{NC}$ & NA & \\
\hline Antimony & $<0.018$ & $\mathrm{NC}$ & NA & \\
\hline Arsenic & 0.068 & 0.031 & NA & \\
\hline Barium & 0.04 & 0.043 & NA & \\
\hline Beryllium & $<0.033$ & $\mathrm{NC}$ & NA & \\
\hline Boron & $<4.1$ & $\mathrm{NC}$ & $\mathrm{NA}$ & \\
\hline Cadmium & 0.37 & 0.26 & NA & \\
\hline Calcium & 43 & 19 & NA & \\
\hline Chromium & 1.5 & 0.22 & NA & \\
\hline Cobalt & 0.54 & 2.2 & NA & \\
\hline Copper & $<0.047$ & $\mathrm{NC}$ & NA & \\
\hline Iron & 6 & 3.4 & NA & \\
\hline Lead & 3.6 & 12 & NA & \\
\hline Magnesium & $<11$ & $\mathrm{NC}$ & NA & \\
\hline Manganese & 0.049 & 0.17 & NA & \\
\hline Mercury & 0.35 & 0.16 & $\mathrm{NA}$ & \\
\hline
\end{tabular}


Table A-6

Incinerator Fuel Gases

\begin{tabular}{|c|c|c|c|c|}
\hline \multirow[b]{2}{*}{ Analyte } & \multicolumn{2}{|c|}{ Natural Gas (99) } & \multicolumn{2}{|c|}{ Combustion Air (97) } \\
\hline & Average & $95 \% \mathrm{Cl}$ & Average & $95 \% \mathrm{Cl}$ \\
\hline Molybdenum & 0.14 & 0.055 & NA & \\
\hline Nickel & 0.74 & 1.6 & NA & \\
\hline Phosphorus & $<26$ & $\mathrm{NC}$ & NA & \\
\hline Potassium & $<190$ & $\mathrm{NC}$ & NA & \\
\hline Selenium & $<0.14$ & $\mathrm{NC}$ & NA & \\
\hline Silicon & 24 & 10 & NA & \\
\hline Sodium & 28 & 12 & NA & \\
\hline Titanium & $<0.37$ & $\mathrm{NC}$ & NA & \\
\hline Vanadium & 0.032 & 0.037 & NA & \\
\hline Zinc & 8.3 & 2.3 & NA & \\
\hline \multicolumn{5}{|l|}{ Gas Composition } \\
\hline Hydrogen (mol \%) & $<1$ & NC & NA & \\
\hline Nitrogen (mol \%) & $<1$ & $\mathrm{NC}$ & NA & \\
\hline Oxygen/Argon (mol \%) & $<1$ & $\mathrm{NC}$ & NA & \\
\hline Carbon Dioxide (mol \%) & $<1$ & $\mathrm{NC}$ & NA & \\
\hline Carbon Monoxide ( $\mathrm{mol} \%$ ) & $<1$ & $\mathrm{NC}$ & NA & \\
\hline Methane (ppmv) & $99 \%$ & $\mathrm{NC}$ & 650 & 120 \\
\hline C2 (ppmv) & 4,500 & 90 & 5 & 3 \\
\hline C3 (ppmv) & 1,400 & 140 & 0.9 & 0.3 \\
\hline C4 (ppmv) & 390 & 50 & 0.2 & 0.2 \\
\hline C5 (ppmv) & 140 & 20 & $<0.1$ & $\mathrm{NC}$ \\
\hline
\end{tabular}

A-34 
Table A-6

Incinerator Fuel Gases

\begin{tabular}{lcccc} 
& Analyte & \multicolumn{2}{c}{ Natural Gas (99) } & \multicolumn{2}{c}{ Combustion Air (97) } \\
\cline { 2 - 5 } & Average & $95 \% \mathrm{Cl}$ & Average & $\mathbf{9 5 \%} \mathrm{Cl}$ \\
\hline $\mathrm{C} 6$ (ppmv) & 53 & 12 & 7.2 & 0.3 \\
\hline $\mathrm{C} 7$ (ppmv) & 110 & 20 & 1 & 1 \\
\hline $\mathrm{C} 8$ (ppmv) & 10 & 1 & 0.6 & 0.05 \\
\hline $\mathrm{H}_{2} \mathrm{~S}(\mathrm{ppmv})$ & $<1$ & $\mathrm{NC}$ & $<1$ & $\mathrm{NC}$ \\
\hline $\mathrm{COS}$ (ppmv) & $<1$ & $\mathrm{NC}$ & $<1$ & $\mathrm{NC}$ \\
\hline $\mathrm{CS}_{2}$ (ppmv) & $<1$ & $\mathrm{NC}$ & $<1$ & $\mathrm{NC}$ \\
\hline
\end{tabular}


Table A-7

Solid Feed Streams

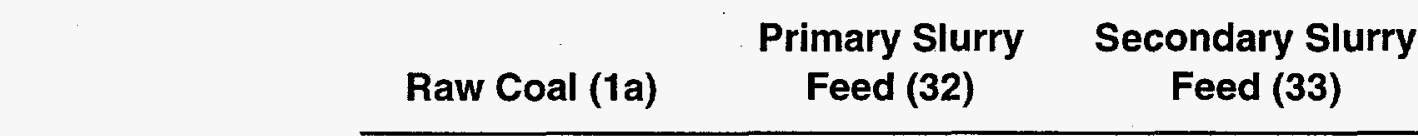

Analyte

Average $95 \% \mathrm{Cl}$ Average $95 \% \mathrm{Cl}$ Average $95 \% \mathrm{Cl}$

\section{Ultimate/Proximate Parameters}

\begin{tabular}{|c|c|c|c|c|c|c|}
\hline Moisture, total (Wt. \%) & 29 & 0.24 & 45 & 0.30 & 48 & 0.44 \\
\hline \% Solids in Slurry (Wt. \%) & NA & & 55 & 0.30 & 52 & 0.44 \\
\hline Ash (Wt. \%) & 6.7 & 0.30 & 6.4 & 0.08 & 7.7 & 0.15 \\
\hline Carbon (Wt. \%) & 70 & 0.37 & 69 & 0.43 & 69 & 0.31 \\
\hline Hydrogen (Wt. \%) & 4.6 & 0.08 & 4.8 & 0.09 & 4.7 & 0.07 \\
\hline Nitrogen (Wt. \%) & 0.99 & 0.02 & 1 & 0.02 & 1.1 & 0.06 \\
\hline Sulfur (Wt. \%) & 0.28 & 0.01 & 0.28 & 0.01 & 0.28 & 0.01 \\
\hline Oxygen (by difference) (Wt. \% ) & 17 & 0.39 & 19 & 0.34 & 17 & 0.31 \\
\hline Volatile Matter (Wt. \%) & 46 & 0.34 & 46 & 0.29 & 45 & 0.48 \\
\hline Fixed Carbon (Wt. \%) & 47 & 0.43 & 48 & 0.32 & 47 & 0.52 \\
\hline Higher Heating Value $(\mathrm{Btu} / \mathrm{lb})$ & 12,000 & 68 & 12,000 & 39 & 12,000 & 46 \\
\hline Chloride $(\mu \mathrm{g} / \mathrm{g})$ & 39 & 5.7 & 43 & 7.0 & 56 & 9.2 \\
\hline Fluoride $(\mu \mathrm{g} / \mathrm{g})$ & 76 & 27 & 45 & 5.0 & 260 & 45 \\
\hline \multicolumn{7}{|l|}{ Metals, $\mu \mathrm{g} / \mathbf{g}$} \\
\hline Aluminum & 6,300 & 400 & 5,800 & 140 & 7,200 & 220 \\
\hline Antimony & 0.12 & 0.023 & 0.01 & 0.031 & 0.43 & 0.047 \\
\hline Arsenic & 0.98 & 0.066 & 0.74 & 0.13 & 2.2 & 0.32 \\
\hline Barium & 370 & 97 & 390 & 8.6 & 500 & 27 \\
\hline
\end{tabular}


Table A-7

Solid Feed Streams

\begin{tabular}{|c|c|c|c|c|c|c|}
\hline \multirow[b]{2}{*}{ Analyte } & \multicolumn{2}{|c|}{ Raw Coal (1a) } & \multicolumn{2}{|c|}{$\begin{array}{l}\text { Primary Slurry } \\
\text { Feed (32) }\end{array}$} & \multicolumn{2}{|c|}{$\begin{array}{c}\text { Secondary Slurry } \\
\text { Feed (33) }\end{array}$} \\
\hline & Average & $95 \% \mathrm{CI}$ & Average & $95 \% \mathrm{Cl}$ & Average & $95 \% \mathrm{Cl}$ \\
\hline Beryllium & 0.27 & 0.029 & 0.21 & 0.04 & 0.31 & 0.039 \\
\hline Boron & 32 & 0.95 & 26 & 2.4 & 35 & 0.77 \\
\hline Cadmium & 0.1 & 0.035 & 0.074 & 0.016 & 1.8 & 0.87 \\
\hline Calcium & 11,000 & 440 & 10,000 & 170 & 13,000 & 280 \\
\hline Chromium & 4.7 & $2.1^{\circ}$ & 3.3 & 1.4 & 5.2 & 1.9 \\
\hline Cobalt & 1.9 & 0.11 & 1.5 & 0.27 & 2.2 & 0.15 \\
\hline Copper & 11 & 0.79 & 9.6 & 1.5 & 15 & 1.6 \\
\hline Iron & 2,400 & 98 & 2,300 & 77 & 2,900 & 84 \\
\hline Lead & 1.3 & 0.20 & 0.85 & 0.16 & 8.3 & 2.2 \\
\hline Magnesium & 2,200 & 93 & 2,100 & 41 & 2,700 & 78 \\
\hline Manganese & 9.9 & 0.62 & 8 & 1.3 & 11.0 & 0.80 \\
\hline Mercury & 0.11 & 0.013 & 0.11 & 0.028 & 0.087 & 0.0086 \\
\hline Molybdenum & 0.55 & 0.054 & 0.49 & 0.091 & 0.73 & 0.073 \\
\hline Nickel & 1.6 & 0.56 & 1.8 & 0.51 & 1.1 & 0.37 \\
\hline Phosphorus & 300 & 50 & 290 & 26 & 310 & 26 \\
\hline Potassium & 210 & 26 & 200 & 50 & 210 & 26 \\
\hline Selenium & 3.4 & 2.6 & 1.4 & 0.54 & 5 & 1.3 \\
\hline Silicon & 11,000 & 790 & 9,900 & 230 & 12,000 & 340 \\
\hline Sodium & 1,000 & 34 & 1,000 & 500 & 1,300 & 50 \\
\hline Strontium & 200 & 50 & 200 & 50 & 200 & 50 \\
\hline
\end{tabular}


Table A-7

Solid Feed Streams

\begin{tabular}{|c|c|c|c|c|c|c|}
\hline \multirow[b]{2}{*}{ Analyte } & \multicolumn{2}{|c|}{ Raw Coal (1a) } & \multicolumn{2}{|c|}{$\begin{array}{c}\text { Primary Slurry } \\
\text { Feed (32) }\end{array}$} & \multicolumn{2}{|c|}{$\begin{array}{c}\text { Secondary Slurry } \\
\text { Feed (33) }\end{array}$} \\
\hline & Average & $95 \% \mathrm{Cl}$ & Average & $95 \% \mathrm{Cl}$ & Average & $95 \% \mathrm{Cl}$ \\
\hline Titanium & 580 & 75 & 540 & 56 & 690 & 26 \\
\hline Vanadium & 13 & 0.87 & 10 & 1.4 & 14 & 0.91 \\
\hline Zinc & 7.9 & 0.81 & 8.6 & 2.5 & 57 & 25 \\
\hline \multicolumn{7}{|l|}{ Radionuclides, pCi/g } \\
\hline Actinium-228@338 KeV & 0.047 & 0.29 & NA & & NA & \\
\hline Actinium-228@911 KeV & 0.12 & 0.45 & NA & & NA & \\
\hline Actinium-228@968 KeV & 0.14 & 0.85 & NA & & NA & \\
\hline Bismuth-212@727 KeV & -0.27 & 1.5 & NA & & NA & \\
\hline Bismuth-214 @ $1120 \mathrm{KeV}$ & 0.31 & 0.11 & NA & & NA & \\
\hline Bismuth-214@1764 KeV & 0.32 & 0.61 & NA & & NA & \\
\hline Bismuth-214@609 KeV & 0.16 & 0.19 & NA & & NA & \\
\hline Lead-210@46 KeV & 0.4 & 1.7 & NA & & NA & \\
\hline Lead-212@238 KeV & 0.13 & 0.029 & NA & & NA & \\
\hline Lead-214@295 KeV & 0.21 & 0.11 & NA & & NA & \\
\hline Lead-214@351 KeV & 0.15 & 0.066 & NA & & NA & \\
\hline Potassium-40@1460 KeV & -0.038 & 0.12 & NA & & NA & \\
\hline Radium-226@226 KeV & 0.057 & 0.038 & NA & & NA & \\
\hline Thallium-208@583 KeV & 0.037 & 0.076 & NA & & NA & \\
\hline Thallium-208@860 KeV & -0.23 & 0.95 & NA & & NA & \\
\hline Thorium-234@63 KeV & 0.13 & 0.29 & NA & & NA & \\
\hline
\end{tabular}


Table A-7

Solid Feed Streams

\begin{tabular}{|c|c|c|c|c|c|c|}
\hline \multirow[b]{2}{*}{ Analyte } & \multicolumn{2}{|c|}{ Raw Coal (1a) } & \multicolumn{2}{|c|}{$\begin{array}{c}\text { Primary Slurry } \\
\text { Feed (32) }\end{array}$} & \multicolumn{2}{|c|}{$\begin{array}{l}\text { Secondary Slurry } \\
\text { Feed (33) }\end{array}$} \\
\hline & Average & $95 \% \mathrm{Cl}$ & Average & $95 \% \mathrm{Cl}$ & Average & $95 \% \mathrm{Cl}$ \\
\hline Thorium-234@92 KeV & 0.047 & 0.38 & NA & & NA & \\
\hline Uranium-235@143 KeV & -0.023 & 0.17 & NA & & NA & \\
\hline
\end{tabular}


Table A-8

Solid Effluent Streams

\begin{tabular}{|c|c|c|c|c|}
\hline \multirow[b]{2}{*}{ Analyte } & \multicolumn{2}{|c|}{ Slag (4) } & \multicolumn{2}{|c|}{ Sulfur (24) } \\
\hline & Average & $95 \% \mathrm{Cl}$ & Average & $95 \% \mathrm{Cl}$ \\
\hline \multicolumn{5}{|l|}{ Ultimate/Proximate Parameters } \\
\hline Ash (Wt. \%) & 89.8 & 5.1 & NA & \\
\hline Carbon (Wt. \%) & 9.5 & 5.2 & NA & \\
\hline Hydrogen (Wt. \%) & 0.15 & 0.07 & NA & \\
\hline Nitrogen (Wt. \%) & 0.04 & 0.05 & NA & \\
\hline Sulfur (Wt. \%) & 0.03 & 0.02 & 98.7 & 7.0 \\
\hline Oxygen (by difference) (Wt. \%) & 0.27 & 0.19 & NA & \\
\hline Volatile Matter (Wt. \%) & NA & & NA & \\
\hline Fixed Carbon (Wt. \%) & NA & & NA & \\
\hline Higher Heating Value (Btu/lb) & NA & & NA & \\
\hline Chloride $(\mu \mathrm{g} / \mathrm{g})$ & 84 & 56 & NA & \\
\hline Fluoride $(\mu \mathrm{g} / \mathrm{g})$ & 200 & 50 & NA & \\
\hline \multicolumn{5}{|l|}{ Metals, $\mu \mathbf{g} / \mathbf{g}$} \\
\hline Aluminum & 91,000 & 5,300 & 16 & 150 \\
\hline Antimony & 1.1 & 0.25 & $<3$ & $\mathrm{NC}$ \\
\hline Arsenic & 6 & 0.96 & $<3$ & $\mathrm{NC}$ \\
\hline Barium & 5,900 & 390 & $<2$ & $\mathrm{NC}$ \\
\hline Beryllium & 3.4 & 0.37 & $<2$ & $\mathrm{NC}$ \\
\hline Boron & 350 & 30 & $<10$ & $\mathrm{NC}$ \\
\hline Cadmium & 0.20 & 0.11 & $<2$ & $\mathrm{NC}$ \\
\hline
\end{tabular}


Table A-8

Solid Effluent Streams

\begin{tabular}{|c|c|c|c|c|}
\hline \multirow[b]{2}{*}{ Analyte } & \multicolumn{2}{|c|}{ Slag (4) } & \multicolumn{2}{|c|}{ Sulfur (24) } \\
\hline & Average & $95 \% \mathrm{Cl}$ & Average & $95 \% \mathrm{Cl}$ \\
\hline Calcium & 160,000 & 9,800 & 20 & 95 \\
\hline Chromium & 76 & 8.3 & 4 & 38 \\
\hline Cobalt & 26 & 2.8 & $<4$ & NC \\
\hline Copper & 150 & 11 & $<2$ & NC \\
\hline Iron & 37,000 & 2,200 & 9 & 38 \\
\hline Lead & 3 & 1.1 & $<3$ & NC \\
\hline Magnesium & 33,000 & 2,200 & 4 & 25 \\
\hline Manganese & 130 & 12 & $<2$ & NC \\
\hline Mercury & 0.020 & 0.006 & 0.095 & 0.19 \\
\hline Molybdenum & 7.6 & 0.52 & $<20$ & NC \\
\hline Nickel & 38 & 4.1 & $<4$ & NC \\
\hline Phosphorus & 4,100 & 210 & NA & \\
\hline Potassium & 2,700 & 250 & $<20$ & NC \\
\hline Selenium & 14 & 5.7 & 24 & 180 \\
\hline Silicon & 160,000 & 9,500 & $<20$ & $\mathrm{NC}$ \\
\hline Sodium & 16,000 & 1,100 & $<20$ & $\mathrm{NC}$ \\
\hline Strontium & 2,300 & 910 & NA & NC \\
\hline Titanium & 8,100 & 500 & 2 & 13 \\
\hline Vanadium & 170 & 13 & $<2$ & $\mathrm{NC}$ \\
\hline Zinc & 47 & 5.6 & 15 & 170 \\
\hline
\end{tabular}


Table A-8

Solid Effluent Streams

Slag (4)

Sulfur (24)

\section{Analyte}

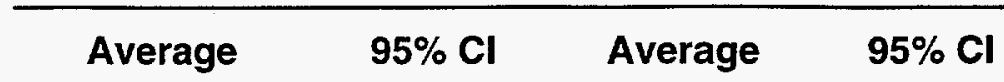

Radionuclides, $\mathrm{pCi} / \mathrm{g}$

\begin{tabular}{|c|c|c|c|}
\hline Actinium-228@338 KeV & 2.3 & 0.9 & NA \\
\hline Actinium-228@911 KeV & 2.5 & 1.1 & NA \\
\hline Actinium-228@968 KeV & 2.5 & 1.1 & NA \\
\hline Bismuth-212@727 KeV & 2.8 & 1.1 & NA \\
\hline Bismuth-214@1120 KeV & 2.7 & 0.9 & NA \\
\hline Bismuth-214@1764 KeV & 2.6 & 1.4 & NA \\
\hline Bismuth-214@609 KeV & 2.7 & 1.2 & NA \\
\hline Lead-210@46 KeV & 0.33 & 1.4 & NA \\
\hline Lead-212@238 KeV & 2.3 & 0.87 & NA \\
\hline Lead-214@295 KeV & 2.8 & 1.2 & NA \\
\hline Lead-214@351 KeV & 2.8 & 1.2 & NA \\
\hline Potassium-40@1460 KeV & 2 & 1.8 & NA \\
\hline Radium-226@226 KeV & 3.5 & 1.3 & NA \\
\hline Thallium-208@ $583 \mathrm{KeV}$ & 0.82 & 0.34 & NA \\
\hline Thallium-208@860 KeV & 1.1 & 0.52 & NA \\
\hline Thorium-234@63 KeV & 1.9 & 2.3 & NA \\
\hline Thorium-234@92 KeV & 1.4 & 0.76 & NA \\
\hline Uranium-235@143 KeV & 0 & 0.56 & NA \\
\hline
\end{tabular}

NA $=$ Not analyzed .

NC $=$ Not calculated .

NS $=$ Not sampled. 
Table A-9

Aqueous Streams

Sweet Water (8)

\begin{tabular}{|c|c|c|}
\hline \multirow[b]{2}{*}{ Analyte } & \multicolumn{2}{|c|}{ Sweet Water (8) } \\
\hline & Average & $95 \% \mathrm{Cl}$ \\
\hline \multicolumn{3}{|l|}{ Water Quality Parameters } \\
\hline $\mathrm{pH}$ & 8.75 & 0.22 \\
\hline Specific conductance ( $\mu$ mhos) & 71.8 & 18 \\
\hline Total Suspended Solids (mg/L) & 1.9 & 3.4 \\
\hline Chemical Oxygen Demand (mg/L) & 53 & 3.9 \\
\hline Total phenolics $(\mathrm{mg} / \mathrm{L})$ & 0.55 & 0.1 \\
\hline \multicolumn{3}{|l|}{ Ionic Species, mg/L } \\
\hline Ammonia as $\mathrm{N}$ & 7.3 & 3.6 \\
\hline Chloride & 0.88 & 0.15 \\
\hline Cyanide, amenable & 0.035 & 0.1 \\
\hline Cyanide, total & 1.5 & 1.2 \\
\hline Fluoride & 1.8 & 0.7 \\
\hline Formate & 3.2 & 0.41 \\
\hline Phosphate, total (as P) & 0.26 & 0.1 \\
\hline Sulfate & $<0.047$ & $\mathrm{NC}$ \\
\hline Thiocyanate & 0.82 & 0.72 \\
\hline \multicolumn{3}{|l|}{ Metals, mg/L } \\
\hline Aluminum & 0.5 & 0.14 \\
\hline Antimony & $<0.076$ & NC \\
\hline Arsenic & 0.0038 & 0.0024 \\
\hline
\end{tabular}


Table A-9

Aqueous Streams

Sweet Water (8)

Analyte

Average $95 \% \mathrm{Cl}$

\begin{tabular}{lcc}
\hline Barium & 0.53 & 0.07 \\
\hline Beryllium & 0.0006 & 0.0013 \\
\hline Boron & 0.039 & 0.051 \\
\hline Cadmium & 0.005 & 0.0024 \\
\hline Calcium & 2.6 & 0.11 \\
\hline Chromium & 0.0087 & 0.003 \\
\hline Cobalt & $<0.004$ & $\mathrm{NC}$ \\
\hline Copper & 0.015 & 0.0044 \\
\hline Iron & 1.2 & 0.14 \\
\hline Lead & 0.33 & 0.25 \\
\hline Magnesium & 1 & 0.058 \\
\hline Manganese & 0.0024 & 0.0034 \\
\hline Mercury & $<0.00003$ & $\mathrm{NC}$ \\
\hline Molybdenum & 0.011 & 0.0051 \\
\hline Nickel & 0.022 & 0.042 \\
\hline Phosphorus & 0.24 & 0.07 \\
\hline Potassium & 0.9 & 0.035 \\
\hline Selenium & 0.032 & 0.011 \\
\hline Silicon & 7.23 & 0.038 \\
\hline Sodium & 3.79 & 0.02 \\
\hline Titanium & (1) & \\
\hline
\end{tabular}

A- 44 
Table A-9

Aqueous Streams

\begin{tabular}{|c|c|c|}
\hline \multirow[b]{2}{*}{ Analyte } & \multicolumn{2}{|c|}{ Sweet Water (8) } \\
\hline & Average & $95 \% \mathrm{Cl}$ \\
\hline Vanadium & $<0.0045$ & NC \\
\hline Zinc & 0.25 & 0.13 \\
\hline \multicolumn{3}{|l|}{ Aldehydes, mg/L } \\
\hline Acetaldehyde & $<0.01$ & NC \\
\hline Acrolein & $<0.01$ & NC \\
\hline Benzaldehyde & $<0.01$ & NC \\
\hline Formaldehyde & $<0.01$ & NC \\
\hline \multicolumn{3}{|c|}{ Volatile Organic Compounds, $\mu \mathrm{g} / \mathrm{L}$} \\
\hline 1,1,1-Trichloroethane & $<0.87$ & NC \\
\hline 1,1,2,2-Tetrachloroethane & $<0.63$ & NC \\
\hline 1,1,2-Trichloroethane & $<0.27$ & NC \\
\hline 1,1-Dichloroethane & $<0.59$ & NC \\
\hline 1,1-Dichloroethene & $<0.34$ & NC \\
\hline 1,2-Dichloroethane & $<0.82$ & NC \\
\hline 1,2-Dichloropropane & $<0.16$ & NC \\
\hline 1,4-Bromofluorobenzene & 46 & 1.2 \\
\hline 1,4-Dichlorobenzene & $<0.56$ & $\mathrm{NC}$ \\
\hline 2-Hexanone & $<0.71$ & NC \\
\hline 4-Methyl-2-pentanone(MIBK) & $<0.49$ & NC \\
\hline Acetone & 5.2 & 3.2 \\
\hline Benzene & $<0.46$ & $\mathrm{NC}$ \\
\hline
\end{tabular}


Table A-9

Aqueous Streams

\begin{tabular}{|c|c|c|}
\hline \multirow[b]{2}{*}{ Analyte } & \multicolumn{2}{|c|}{ Sweet Water (8) } \\
\hline & Average & $95 \% \mathrm{Cl}$ \\
\hline Bromodichloromethane & $<0.37$ & $\mathrm{NC}$ \\
\hline Bromomethane & $<0.54$ & NC \\
\hline Carbon disulfide & $<0.49$ & NC \\
\hline Carbon tetrachloride & $<0.80$ & NC \\
\hline Chlorobenzene & $<0.32$ & NC \\
\hline Chloroethane & $<0.77$ & $\mathrm{NC}$ \\
\hline Chloroform & $<0.53$ & NC \\
\hline Chloromethane & $<0.52$ & $\mathrm{NC}$ \\
\hline Dibromochloromethane & $<0.25$ & $\mathrm{NC}$ \\
\hline Ethyl benzene & $<0.59$ & $\mathrm{NC}$ \\
\hline Methyl ethyl ketone & $<1.6$ & NC \\
\hline Methylene chloride & $<3 . \dot{0}$ & $\mathrm{NC}$ \\
\hline Styrene & $<0.43$ & NC \\
\hline Tetrachloroethene & $<0.54$ & $\mathrm{NC}$ \\
\hline Toluene & $<0.41$ & $\mathrm{NC}$ \\
\hline Tribromomethane (Bromoform) & $<0.56$ & NC \\
\hline Trichloroethene & $<0.46$ & NC \\
\hline Vinyl acetate & $<0.64$ & NC \\
\hline Vinyl chloride & $<0.69$ & $\mathrm{NC}$ \\
\hline cis-1,3-Dichloropropene & $<0.41$ & $\mathrm{NC}$ \\
\hline m\&p-Xylene & $<0.51$ & NC \\
\hline
\end{tabular}


Table A-9

Aqueous Streams

Sweet Water (8)

\begin{tabular}{|c|c|c|}
\hline \\
\hline Analyte & Average & $95 \% \mathrm{Cl}$ \\
\hline o-Xylene & $<0.40$ & $\mathrm{NC}$ \\
\hline trans-1,2-Dichloroethene & $<0.54$ & $\mathrm{NC}$ \\
\hline trans-1,3-Dichloropropene & $<0.42$ & NC \\
\hline \multicolumn{3}{|c|}{ Semivolatile Organic Compounds, $\mu \mathrm{g} / \mathrm{L}$} \\
\hline 1,2,4-Trichlorobenzene & $<0.53$ & $\mathrm{NC}$ \\
\hline 1,2-Dichlorobenzene & $<0.64$ & $\mathrm{NC}$ \\
\hline 1,3-Dichlorobenzene & $<0.43$ & NC \\
\hline 1,4-Dichlorobenzene & $<1.7$ & $\mathrm{NC}$ \\
\hline 2,4,5-Trichlorophenol & $<0.34$ & $\mathrm{NC}$ \\
\hline 2,4,6-Tribromophenol & 160 & 32 \\
\hline 2,4,6-Trichlorophenol & $<0.41$ & $\mathrm{NC}$ \\
\hline 2,4-Dichlorophenol & $<0.43$ & $\mathrm{NC}$ \\
\hline 2,4-Dimethylphenol & $<0.70$ & $\mathrm{NC}$ \\
\hline 2,4-Dinitrophenol & $<1.3$ & $\mathrm{NC}$ \\
\hline 2,4-Dinitrotoluene & $<0.34$ & NC \\
\hline 2,6-Dinitrotoluene & $<0.65$ & $\mathrm{NC}$ \\
\hline 2-Chloronaphthalene & $<0.84$ & $\mathrm{NC}$ \\
\hline 2-Chlorophenol & $<0.57$ & $\mathrm{NC}$ \\
\hline 2-Fluorobiphenyl & 61.2 & 15 \\
\hline 2-Fluorophenol & 160 & 33 \\
\hline 2-Methylnaphthalene & $<0.86$ & $\mathrm{NC}$ \\
\hline
\end{tabular}


Table A-9

Aqueous Streams

Sweet Water (8)

\begin{tabular}{|c|c|c|}
\hline Analyte & Average & $95 \% \mathrm{Cl}$ \\
\hline 2-Methylphenol & $<0.51$ & NC \\
\hline 2-Nitroaniline & $<0.55$ & $\mathrm{NC}$ \\
\hline 2-Nitrophenol & $<0.82$ & $\mathrm{NC}$ \\
\hline 3,3'-Dichlorobenzidine & $<3.9$ & $\mathrm{NC}$ \\
\hline 3-Nitroaniline & $<0.54$ & $\mathrm{NC}$ \\
\hline 4,6-Dinitro-2-methylphenol & $<3.1$ & NC \\
\hline 4-Aminobiphenyl & $<4.3$ & $\mathrm{NC}$ \\
\hline 4-Bromophenylphenyl ether & $<0.31$ & $\mathrm{NC}$ \\
\hline 4-Chloro-3-methylphenol & $<0.40$ & $\mathrm{NC}$ \\
\hline 4-Chlorophenylphenyl ether & $<0.48$ & NC \\
\hline 4-Methylphenol/3-Methylphenol & 0.49 & 1.1 \\
\hline 4-Nitroaniline & $<0.66$ & NC \\
\hline 4-Nitrophenol & $<0.81$ & NC \\
\hline Acenaphthene & $<0.64$ & $\mathrm{NC}$ \\
\hline Acenaphthylene & $<0.65$ & $\mathrm{NC}$ \\
\hline Acetophenone & $<0.57$ & NC \\
\hline Aniline & $<1.1$ & $\mathrm{NC}$ \\
\hline Anthracene & $<0.70$ & $\mathrm{NC}$ \\
\hline Benz(a)anthracene & $<0.77$ & $\mathrm{NC}$ \\
\hline Benz(a)pyrene & $<0.70$ & NC \\
\hline Benzidine & $<21$ & $\mathrm{NC}$ \\
\hline
\end{tabular}


Table A-9

Aqueous Streams

\begin{tabular}{|c|c|c|}
\hline \multirow[b]{2}{*}{ Analyte } & \multicolumn{2}{|c|}{ Sweet Water (8) } \\
\hline & Average & $95 \% \mathrm{Cl}$ \\
\hline Benzo(b)fluoranthene & $<0.69$ & $\mathrm{NC}$ \\
\hline Benzo(g,h,i)perylene & $<0.74$ & $\mathrm{NC}$ \\
\hline Benzo(k)fluoranthene & $<1.0$ & $\mathrm{NC}$ \\
\hline Benzoic acid & 9.2 & 26 \\
\hline Benzyl alcohol & $<0.45$ & $\mathrm{NC}$ \\
\hline Butylbenzylphthalate & $<0.50$ & NC \\
\hline Chrysene & $<0.78$ & NC \\
\hline Di-n-butylphthalate & $<0.50$ & $\mathrm{NC}$ \\
\hline Di-n-octylphthalate & $<0.68$ & $\mathrm{NC}$ \\
\hline Dibenz $(a, h)$ anthracene & $<0.86$ & $\mathrm{NC}$ \\
\hline Dibenzofuran & $<0.64$ & $\mathrm{NC}$ \\
\hline Diethylphthalate & $<0.69$ & $\mathrm{NC}$ \\
\hline Dimethylphthalate & $<0.43$ & $\mathrm{NC}$ \\
\hline Diphenylamine/N-NitrosoDPA & $<0.69$ & $\mathrm{NC}$ \\
\hline Fluoranthene & 2.6 & 1.1 \\
\hline Fluorene & $<0.75$ & $\mathrm{NC}$ \\
\hline Hexachlorobenzene & $<0.57$ & NC \\
\hline Hexachlorobutadiene & $<0.76$ & $\mathrm{NC}$ \\
\hline Hexachlorocyclopentadiene & $<2.1$ & $\mathrm{NC}$ \\
\hline Hexachloroethane & $<1.9$ & $\mathrm{NC}$ \\
\hline Indeno(1,2,3-cd)pyrene & $<0.81$ & $\mathrm{NC}$ \\
\hline
\end{tabular}


Table A-9

Aqueous Streams

Sweet Water (8)

\begin{tabular}{|c|c|c|}
\hline \multirow[b]{2}{*}{ Analyte } & \multirow[b]{2}{*}{ Average } & \multirow[b]{2}{*}{$95 \% \mathrm{Cl}$} \\
\hline & & \\
\hline Isophorone & $<0.36$ & $\mathrm{NC}$ \\
\hline N-Nitroso-di-n-propylamine & $<0.60$ & $\mathrm{NC}$ \\
\hline N-Nitrosodimethylamine & $<0.54$ & NC \\
\hline Naphthalene & $<0.76$ & NC \\
\hline Nitrobenzene & $<0.58$ & $\mathrm{NC}$ \\
\hline Pentachloronitrobenzene & $<1.9$ & $\mathrm{NC}$ \\
\hline Pentachlorophenol & $<0.51$ & NC \\
\hline Phenanthrene & $<1.9$ & $\mathrm{NC}$ \\
\hline Phenol & 400 & 84 \\
\hline Pyrene & 11 & 5.6 \\
\hline bis(2-Chloroethoxy)methane & $<0.58$ & $\mathrm{NC}$ \\
\hline bis(2-Chloroethyl)ether & $<0.63$ & $\mathrm{NC}$ \\
\hline bis(2-Chloroisopropyl)ether & $<0.59$ & $\mathrm{NC}$ \\
\hline bis(2-Ethylhexyl)phthalate & $<1.0$ & $\mathrm{NC}$ \\
\hline p-Chloroaniline & $<0.95$ & $\mathrm{NC}$ \\
\hline p-Dimethylaminoazobenzene & $<0.51$ & NC \\
\hline
\end{tabular}

